University of Louisville

ThinkIR: The University of Louisville's Institutional Repository

Electronic Theses and Dissertations

8-2004

\title{
The jugular vein of empire : the imperial attachment to the Suez Canal from 1875 to 1956.
}

Matthew Church

University of Louisville

Follow this and additional works at: https://ir.library.louisville.edu/etd

\section{Recommended Citation}

Church, Matthew, "The jugular vein of empire : the imperial attachment to the Suez Canal from 1875 to 1956." (2004). Electronic Theses and Dissertations. Paper 251.

https://doi.org/10.18297/etd/251

This Master's Thesis is brought to you for free and open access by ThinkIR: The University of Louisville's Institutional Repository. It has been accepted for inclusion in Electronic Theses and Dissertations by an authorized administrator of ThinkIR: The University of Louisville's Institutional Repository. This title appears here courtesy of the author, who has retained all other copyrights. For more information, please contact thinkir@louisville.edu. 
The Jugular Vein of Empire: The Imperial

Attachment to the Suez Canal from 1875 to 1956.

\author{
By \\ Matthew Church \\ B.A., Bellarmine University, 2001 \\ A Thesis \\ Submitted to the Faculty of the \\ Graduate School of the University of Louisville \\ In Partial Fulfillment of the Requirements \\ for the Degree of \\ Master of Arts \\ Department of History \\ University of Louisville \\ Louisville, KY
}

August 2004 


\section{Dedication}

This thesis is dedicated to my parents

Dr. Stephen Church and Diane Church

For all their love, encouragement, and support

And

My late grandfather Leo Goulet, whom I miss constantly

and wish was here to read this thesis 


\section{Acknowledgements}

I would like to begin by thanking my thesis advisor Dr. John McLeod for his patience, guidance, and suggestions. I have the utmost respect and admiration for Dr. McLeod and was truly honored to have him serve as my thesis advisor. Dr. McLeod has extreme dedication to this research and reviewed chapters while in India. I would also like to thank the other members of my committee Dr. Benjamin Harrison and Dr. Charles Ziegler for agreeing to sit on my committee and for that they have my extreme gratitude. Additionally, I am indebted to the history department at the University of Louisville for providing funding for my graduate study through a graduate student scholarship and graduate assistantship. I am especially grateful to Rita Hettinger and Lee Keeling of the History Department, whom I have worked for and with during the past two years and are two of the most wonderful people I have ever had the privilege of meeting. I would also like to thank both Dr. Thomas Mackey, chair of the history department, and Dr. Wayne Lee, Graduate director of the department, for their guidance over the past few years. Dr. Mackey was especially helpful and took time read drafts of this thesis and provided insightful comments for both this thesis and my other writing. The completion of my thesis was also made possible by Dr. Bruce Adams and Dr. Justin McCarthy of the history department and Dr. Tomarra Adams from the Dean's Office under whom I have worked throughout the past two years. I would also like to thank the staffs of the W.L. Lyons Brown library at Bellarmine University, who were always happy to provide a computer and a smile to a returning alumnus, the Ekstrom Library at the University of 
Louisville, the University of Louisville Interlibrary loan department, and the Louisville Free Public Library. Immeasurable support has also been provided by my fellow graduate students and honor society members, in particular, Connor Bell, Jennie Cole, Nathan Coleman, Gwen Krupinski, Gail Nall, and Tony Robinson of the University of Louisville, Fedja Buric of the University of Illinois, Nathaniel Cadle of the University of North Carolina, and Madeline Hunt of Ball State University. I have also benefited from the advice of Dr. Timothy Welliver of Bellarmine University, who was my undergraduate advisor and continues to be both a mentor and friend. Finally my friends, who have always been there for me and have never hesitated to lend a sympathetic ear or provide a distraction from research. I am especially thankful to Beck Beckman, Kelly Berg, Christine Bowman, Jay Davis, Rob and Andrea Gieszl, Adrian Goodloe, Wes Goodloe, Pat and Jenny Hoban, Steve Kaelin, Pete Manning, Jason Mucci, Graham Newton, Will Shoemaker, Erinn Waggoner, Brian Warren, Matt and Brenda Witten, and Amy Zuccaro. Finally, none of this would have been possible without the support of my parents and siblings. My sisters Megan and Emily have been a constant source of support. My brother Ryan has been constant in his advice and friendship, and is both my brother and best friend. Words cannot describe how much my parents mean to me or have aided me in this process and a dedication is the least I can do to repay their support. 


\begin{abstract}
The Jugular Vein of Empire: Imperial Attachment to the Suez Canal from 1875 to 1956 Matthew Church
\end{abstract}

August 2, 2004

This thesis is examines the imperial attachment to the Suez Canal from 1875 to 1956. It begins with the canal share purchase by the Disraeli Government and ends with the Suez Crisis. Traditional scholarship views relations between the Britain and the Suez Canal as disjointed and highlighted by sporadic significant events. This thesis aims to evaluate the history of these relations. The thesis is divided into five chapters with the imperial attachment to the canal is divided into three chronological periods. In each phase of attachment there is at least one distinct policy shift and re-evaluation of the importance of the Suez Canal. While canal importance fluctuated, the continued re-strengthening of the attachment demonstrates a continuous attachment to the canal. These findings disprove traditional view of Anglo-Suez relations being disjointed. Summarily, this thesis proved the existence of a continuous imperial attachment to the Suez Canal from 1875 to 1956. 
Table of Contents

Page

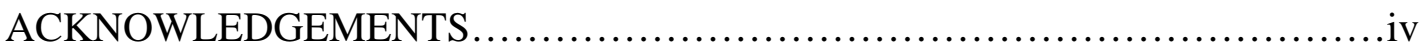

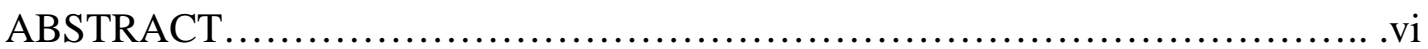

\section{CHAPTER}

I. The Constant Attachment: Britain and the Suez Canal.......................1

II. Disraeli’s Coup and Gladstone’s Reluctant Intervention...................29

III. Fighting for the Canal...............................................62

IV. $\quad$ Parting Ways with the Canal.........................................96

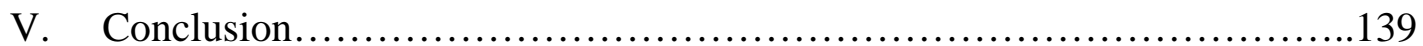

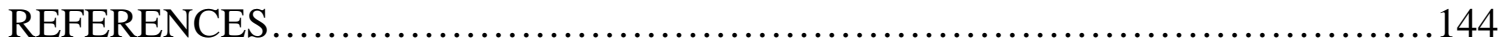

CURRICULUM VITAE......................................................153 


\section{Chapter I The Constant Attachment: Britain and the Suez Canal}

On April 25, 1859, Ferdinand de Lesseps struck the ceremonial first blow at what would become the Suez Canal at the town later to be known as Port Said. ${ }^{1}$ Upon completion, the canal stretched one hundred miles. It connected the Red Sea with the Mediterranean and opened on November 17, 1869. The Suez Canal cut the travel time between Europe and the Far East and served to invigorate the Indian trade even further; however, an unintended problem with the canal arose. The canal belonged to Egypt, but also belonged to mankind. ${ }^{2}$ Historian Hugh Schonfield believed the canal had two owners: Egypt and the rest of the world. The universal use of the canal caused it to become an international concern and gave impetus for European powers to involve themselves in Egyptian affairs. The canal not only represented a great development in trade and technology, but also generated a new point of disputation among the powers of Europe. The party most interested in the canal was Britain, despite having opposed the canal construction and taken steps to obstruct the completion of the project. To the British, the canal was of dire importance as the gateway to India. The canal would earn titles such as nodal point, jugular vein of empire, and Clapham junction, a one hundred

\footnotetext{
${ }^{1}$ Hugh Schonfield, The Suez Canal in Peace and War 1869-1969 (Coral Gables, FL.: University of Miami Press, 1969), 37.

${ }^{2}$ Ibid., $\mathrm{x}$.
} 
mile waterway on which the survival of the British Empire rested and which was the main fulcrum of continued British control over India. The British were intimately associated with the canal from the inception of the project to the aftermath of the nationalization of the canal in late 1956. The history of British involvement in the Suez Canal from 1875 to 1956 demonstrates a multitude of attitudes towards the canal and a constant British willingness to defend the canal as if it were part of the Home Islands. In reference to the canal, the term British refers to the military and political leaders of Britain. While the common populace of Britain possessed a certain affinity for the canal, the officials of the British government formulated and affected policy towards the Suez Canal.

The British involvement with the Suez Canal existed long before its construction. The importance of Egypt was most vividly illustrated by the French invasion of Egypt in 1798. Prior to 1800, the British had expected any challenge to India and the Middle East to come from the sea and concentrated their defense efforts on a strong navy to aid in the protection of both India and the road to India. The situation changed when a French force under Napoleon invaded and occupied Egypt in 1798. The French invasion forced Britain to deal with the vulnerability of the crossroads of the world, from which her Indian trade and Eastern Empire could be menaced. A foreign power controlling the overland route to India could harass British trade in the Middle East, prevent British supply ships from taking on food and supplies in the region, and presumably march on the frontier of India. In 1800, the British took the momentous decision to send an 
expeditionary force to aid the Ottomans in repelling the French and to evict them from Egypt. According to historian Edward Ingram, this decision demonstrated the British priority for colonial and imperial matters over those of the continent and showed a shift in British policy. ${ }^{3}$ The French invasion not only demonstrated a veritable weakness in the British defense of India, but also ushered in a British policy of regarding the Middle East, particularly Egypt, as a vital barrier for the safeguard of the Indian Empire.

The granting of the canal concession in 1856 and the possibility of a French canal controlling the route to India sent British politicians and officials into a panic. The Egyptian Government granted the concession a year before the 1857 Revolt in India, which was put down with much effort by the British and caused a revision of their methods of rule in India. ${ }^{4}$ French control of the canal would result in quicker access to India by French troops and the denial of passage to British troops through the canal. The shares of the Canal Company were owned by private French investors, but their interests were safeguarded by the French Government. In the event of a French invasion of India, British reinforcements would be sent to India via the Cape Route, which was a slower journey than through the canal. Also, British power partially derived from the strength of the Indian Army and an attack on India would severely weaken the power of the empire. The multitudinous threat of a French canal cannot be emphasized enough and the opportunity to gain control of the canal was in the minds of British statesmen during this

\footnotetext{
${ }^{3}$ Edward Ingram, The British Empire as a World Power (London: Frank Cass, 2001), 237-261.

${ }^{4}$ For a description of the 1857 revolt see John McLeod, A History of India (London: Greenwood Press, 2002) and for a seminal study on post mutiny policy in India see Sarvelli Gopal, British Policy in India 1858-1905 (Cambridge: Cambridge University Press, 1965).
} 
time. The Egyptian Government presented the British with an opportunity in 1875 to purchase shares in the Suez Canal Company. The Suez Canal Company was the administrative body of the canal and supervised the running of the canal. ${ }^{5}$ It obtained its income through dues and tolls paid by ships passing through the canal. The canal was run by a board of directors and out of a possible four hundred thousand shares, 207, 600 were allotted to French investors and 177, 642 to Egypt. ${ }^{6}$ The extravagant debts and financial mishaps of Khedive Ismail of Egypt drove the country to bankruptcy and Ismail searched for a way to regain solvency. The answer it seemed was to sell off the Egyptian shares of the Suez Canal to the highest bidder. Egypt expected bidders to come from France and generate a wholly French ownership of the canal. However, the government of Disraeli intervened and, without parliamentary approval, purchased the canal shares on November 25, 1875. ${ }^{7}$ The share purchase gave Britain 176,602 shares, close to half of the total shares in the company. ${ }^{8}$ Disraeli viewed the canal as the "key to India," as many Englishmen did, and the purchase was a self professed triumph. According to Disraeli, Queen Victoria termed the purchase a great event in modern politics and Disraeli believed he had prevented the canal from becoming entirely French. ${ }^{9}$ Britain owned

\footnotetext{
${ }^{5}$ John Marlowe, A History of Modern Egypt and Anglo-Egyptian Relations 1800-1956 (Hamden, CT.: Archon Books, 1965), 61-71.

${ }^{6}$ Schonfield, 35.

${ }^{7}$ Disraeli to Lady Bradford 11-25-1875 and 11-26-75 in Marquis of Zetland ed., Letters of Disraeli to Lady Chesterfield and Lady Bradford 2 vols. (New York: D. Appleton \& Co., 1929), 461-463.

${ }^{8}$ Schonfield, 47.

${ }^{9}$ Disraeli to Lady Bradford 11-25-1875 and 11-26-75 in Zetland, 461-463.
} 
nearly half of the canal shares and found commonality with France in regard to the need for the canal to stay open and the proper administration of Egypt.

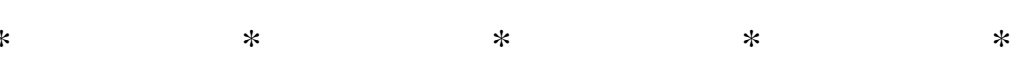

Still necessary is a review of the relevant literature on the topic. There are several works on the Suez Canal that provide a wealth of information and propose different arguments on the importance of the canal. Charles Hallberg's The Suez Canal: Its History and Diplomatic Importance is a fine work that outlines the British attachment to the canal up to the 1930 s. $^{10}$ The work purports not only the accepted thesis that as long as India was under British control the canal would be indispensable to the British Empire, but also argues that the British would take any measure possible to avoid other powers gaining influence over the canal. Hallberg asserts rightly that in times of trouble the canal itself would become a battleground as long as the British controlled India. Additionally, Hugh Schonfield's The Suez Canal in Peace and War 1869-1969 provides a chronological history of the canal and also addresses the duality of the canal as belonging to both Egypt and the world. Schonfield traces the history of the canal itself in parallel to the British preoccupation with the canal and the diplomatic view of the canal in both the twentieth century and in light of the Eastern Question. Schonfield argues that the canal belonged to Egypt and the world. According to Schonfield, this dual ownership made the canal an infringement on Egyptian sovereignty. Finally, D.A. Farnie's East and West of

\footnotetext{
${ }^{10}$ Charles Hallberg, The Suez Canal: Its History and Diplomatic Importance (New York: Columbia University Press, 1931).
} 
the Suez 1854-1956 is an exhaustive study of the canal and focuses on every conceivable economic benefit of the canal to Britain. ${ }^{11}$ It also addresses the national response to the purchase of the canal shares by Disraeli in 1875 . Farnie argues the economic benefit of the canal to Britain was the reason for the attachment.

The works of Hallberg, Schonfield, and Farnie are useful to the study of the Suez Canal, but their arguments are incomplete. Hallberg was correct in stressing the military importance of the canal and that in times of trouble the canal would become a battlefield. He is incorrect in arguing the attachment to the canal was predicated on British control of India. As this paper will show, the loss of India did little to lessen the imperial attachment to the canal and new reasons were found to justify continued British control of the canal. Hallberg's argument suffers due to its publication date and the state of the empire at the time. Farnie correctly argues the economic importance of the canal, but fails to include a focus on non-economic factors. The security reasons and the attachment generated through British military victories are omitted. Schonfield provides an interesting argument about the canal's effect on Egyptian sovereignty, but miscategorizes the forces acting against Egypt. While Schonfield suggests it was the world that owned the canal and worked against Egyptian sovereignty, only Britain undertook such actions. With the exception of indirect French financial control in the late 1870s, Britain was the only country to take direct action against Egypt for the sake of the canal until 1956. These arguments merit a revision.

\footnotetext{
${ }^{11}$ D.A. Farnie, East and West of Suez: the Suez Canal in History 1854-1956 (Oxford: Clarendon Press 1969).
} 
Historian Steven Morewood observed that studies of the British in the Mediterranean have focused on either early British involvement in the region or the Suez Crisis. ${ }^{12}$ Morewood aimed to remedy this situation by focusing on interwar defense strategy in Egypt, but only added another field to the multitude of possible areas of focus when looking at Britain and the Suez Canal. As Morewood observed, most studies tend to care about three things: the share purchase, the 1882 invasion, and the Suez Crisis. Recent studies of defense strategy have existed on their own from these prior three topics and tend to be more focused on British lack of preparation for World War II. Additional studies on the Mandate system have devolved into a recounting of the struggle between nationalists and British imperial desire, never incorporating the parts into the whole. Even histories of the canal such as those by Farnie, Hallberg, and Schonfield, tend to provide diplomatic histories of the canal and noteworthy events, lacking a linkage or systemic approach. The most common error is to assume the canal was only important because of India. This idea is incorrect. Many events involving Britain and the Suez Canal exist from differing sources, no attempt to link them into one coherent study has been undertaken.

While the works of Farnie, Schonfield, and Hallberg deal solely with the canal, other works dealing with particular events in British policy towards the Suez Canal were used in this study. On the topic of the 1882 invasion, the most detailed commentary lies in Robert Harrison's dissertation Road to Suez: Gladstone and the Egyptian Crisis of

\footnotetext{
${ }^{12}$ Steven Morewood, "Protecting the Jugular Vein of Empire; the Suez Canal in British Defense Strategy 1919-1941,” in War \& Society Vol. 10, No.1 (May 1992), 82.
} 
1882, which not only provides an excellent depiction of the events, but also disputes the traditional impetus for invasion and notes that the Egyptian forts and coastal batteries were no legitimate threat, but did provide a casus belli. ${ }^{13}$ Foreign policy commentaries on the invasion also proved useful. The traditional account of the 1882 invasion and the argument that one driving force was the embarrassing situation of England being a minority shareholder in a French company can be found in Paul Knaplund's Gladstone’s Foreign Policy. A comparison of the imperial motives of Gladstone and Disraeli is a centerpiece of C.C. Eldridge's England's Mission: the Imperial Idea in the Age of Gladstone and Disraeli. ${ }^{14}$ Also included in this book is the contention that the Suez Canal held up the empire, allowed the empire to function, and that Disraeli succeeded in gaining the interest of Queen Victoria in the empire. Kenneth Bourne’s The Foreign Policy of Victorian England 1830-1902 provides an interesting background to the year of the share purchase and is Palmerston centric in its composition. ${ }^{15}$ However the work does depict the shifting power of the British Empire in terms of eliminating Continental threats and only having to deal with Russia during the time of Gladstone and Disraeli. Bourne provides a solid treatment to the German concession in 1888 to build the Berlin to Baghdad Railway, which constituted a grave threat to the Indian Empire if construction was completed. The railway allowed for the possible transport of Ottoman and German

\footnotetext{
${ }^{13}$ Robert Harrison, Road to Suez: Gladstone and the Egyptian Crisis of 1882 (Ph.D. diss., University of Southern California, 1987).

${ }^{14}$ C.C. Eldridge, England's Mission: the Imperial Idea in the Age of Gladstone and Disraeli (Chapel Hill, NC: University of North Carolina Press, 1993).

${ }^{15}$ Kenneth Bourne, The Foreign Policy of Victorian England (Oxford: Clarendon Press, 1970).
} 
troops to Baghdad and the border of India. The rail provided the Ottoman Government a chance to attack or subvert British influence in the Gulf Dependencies.

Additionally, two works dealing with the charges of collusion during the Suez Crisis were particularly useful. A multitude of books on the Suez collusion exist with Terrance Robertson's Crisis: the Inside Story of the Suez Conspiracy being the most important. ${ }^{16}$ Robertson focuses on Lester Pearson and the dealings at the United Nations over Suez, which ultimately resulted in the creation of the United Nations Expeditionary Force, the first UN peacekeeping force. Robertson is also one of the first authors to accuse the British and French of collusion with Israel in the crisis and believes the AngloFrench ultimatum was not as idealistic as Eden and Lloyd would have scholars believe. Donald Neff's Warriors at Suez: Eisenhower takes American into the Middle East provides a divergent view of the crisis and depicts the Americans as bringing justice to the Middle East and standing against the neo-colonial action of the British and French. ${ }^{17}$ However, this work glosses over the comments of Dulles about Nasser needing to be made to disgorge the canal, which was taken as tacit approval according to Eden and Lloyd.

This paper suggests that a clear British attachment to the Suez Canal existed from 1875 to 1956 . This paper differs from others in that it will begin with the acknowledgement that the Suez Canal was always important to Britain and when reasons

\footnotetext{
${ }^{16}$ Terence Robertson, Crisis: the Inside Story of the Suez Conspiracy (N.Y.: Atheneum, 1965).

${ }^{17}$ Donald Neff, Warriors at Suez: Eisenhower Takes America into the Middle East (New York: Linden Press, 1981).
} 
for importance disappeared, such as the end of the Indian Empire, the British found new reasons for its importance. The rationale for this replacement is that by the twentieth century and especially after the World Wars, the Suez Canal had earned its place in the mantle of empire and was for all practical purposes British. It was part of the empire and had long been described as invaluable and accepted by the British as such. The attachment came from two main areas: strategic/diplomatic importance and romanticism/imperial thought. By focusing on important events in British history involving the Suez Canal, the history of the imperial attachment will be demonstrated and in the end, the canal will be shown to have always been important to the British Empire.

This paper aims to address and evaluate the imperial attachment to the Suez Canal from 1875 to 1956 and to outline and evaluate the shifts in British policy in regard to the canal. The approach encompasses a fusion of diplomatic history, British military history, imperial thought, and traditional British imperial history. The date for the beginning of this work centers around the purchase of the canal shares by Disraeli in 1875. The study will be divided into three main periods: 1875 -1914, 1914-1945, and 1945-1956. Analyzed in the years in questions are both the high point of the British Empire under Queen Victoria and the Disraeli and Gladstone ministries, the perils of the empire during the period of the World Wars, and the Suez crisis, which is widely held as the death knell of empire. The rationale for the division is policy based. In the first phase from 1875 to 1914, the early British involvement will be addressed and will entail the share purchase, Dual Control, and the intervention of 1882. The first phase also addresses the start of 
British suzerainty over Egypt and the diplomatic history pertinent to early twentieth century diplomacy and the Mediterranean question. The second phase addresses World War I and World War II, but also extends to the interwar era to showcase not only the shifting British policies towards European powers, but also the last great expansion of the empire into the Middle East. The third phase begins with the election of the Attlee government in 1945 and also depicts the postwar order, the beginnings of the Cold War, the struggles of British definition in the Cold War, and the response of the empire to panArabism and decolonization. Imbedded in each phase is a perceivable policy shift in regard to the canal, generally shifting from dire importance to expendability. The completion of this study will not only show the consistent attachment to the canal, in differing forms, but also demonstrate that contrary to general scholarship, the canal represented more to the empire than just a gateway to India and was still worth fighting for in 1956. The impetus for this study stems from the tragic story of Sir Anthony Eden and why in 1956 he staked his reputation and British world power on confronting Nasser over the canal nationalization. After all, the canal was rightfully Egyptian, the action was legal, and with India independent, the necessity of the canal was no longer apparent. The interesting aspect of the attachment to the canal was the canal was run by a private company, in which the British Government were a minority shareholder, and was only under direct British control during World War I. By the end of this work, the reasons for this importance and place in imperial lore will become clear. 
In terms of general histories, many were useful, but as with all historical works primary documents are the building blocks of any study and no primary source has been more useful than Hansard's Parliamentary Debates. ${ }^{18}$ While many volumes of Hansard's were consulted in this work, the main focus is on the debates from 1875 to 1882 . These debates aid in understanding the formation of the imperial attachment. By the second phase, a sense of imperial attachment to the canal and an elevation to the imperial mantle existed, but the initial debates over the canal purchase and later intervention in Egypt are most noteworthy. Additional documentary evidence was obtained through J.C. Hurewitz’s Diplomacy in the Near and Middle East: A Documentary Record. ${ }^{19}$ Numerous other primary sources were used in the discussion of the first phase of attachment. The Marquis of Zetland's Letters of Disraeli to Lady Chesterfield and Lady Bradford proved quite useful in tracing the day to day events of the Disraeli ministry and the prime minister's response to the Suez purchase. On the topic of Gladstone, the two most useful sources were The Political Correspondence of Mr. Gladstone and Lord $\underline{\text { Granville 1876-1886 and The Gladstone Diaries with Cabinet Minutes and Ministerial }}$

\footnotetext{
18 The most useful volumes were the following: Hansard's Parliamentary Debates 1876 Vo. 227 ( London: Cornelius Books, 1876 and New York: Kraus Reprint Company, 1971), Hansard's Parliamentary Debates 1877 Vol. 234 (London: Cornelius Books, 1877 and New York: Kraus Reprint Company, 1971), Hansard’s Parliamentary Debates 1877 Vol. 235 (London: Cornelius Books, 1877 and New York: Kraus Reprint Company, 1971), Hansard's Parliamentary Debates 1878 Vol. 242 (London: Cornelius Books, 1878 and New York: Kraus Reprint Company, 1971), Hansard’s Parliamentary Debates 1882 Vol. 269 (London: Cornelius Books, 1882 and New York: Kraus Reprint Company, 1971), Hansard's Parliamentary Debates 1882 Vol. 270 (London: Cornelius Books, 1882 and New York: Kraus Reprint Company, 1971), and Hansard’s Parliamentary Debates Vol. 271 (London: Cornelius Books, 1882 and New York: Kraus Reprint Company, 1971).

19 J.C. Hurewitz, Diplomacy in the Near and Middle East: A Documentary Record 2 vols. (Princeton, N.J.: Van Nostrund, 1956.
} 
Correspondence, which both yielded insight into the decision to invade Egypt in 1882 and the varying attempts made to forestall invasion by British forces. ${ }^{20}$ The latter is also noteworthy for its inclusion of Gladstone's admission that the canal was the only British interest in Egypt. ${ }^{21}$ Also of value was a compilation of the Midlothian Speeches, which showcased the anti-Turkish policy of Gladstone’s 1880 Campaign and the supposed desire for the infusion of a more moral foreign policy. ${ }^{22}$ The best primary account of the British administrative experience in Egypt is Lord Cromer's Modern Egypt. ${ }^{23}$ For a supplement to Cromer's work and address of the day to day routine of British officials in Egypt see Lord Edward Cecil's The Leisure of an Egyptian Official. ${ }^{24}$

There were many primary sources used in the analysis of the second phase of attachment and deal with the British experience in World War I and World War II. No discussion of World War I in the Middle East is complete without mention of the fame seeking T.E. Lawrence. Seven Pillars of Wisdom: A Triumph and Revolt in the Desert are both useful in their conveyance of Lawrence's experience in the war; however, it is necessary to balance these works out with more recent scholarship since Lawrence tends to take credit for the entire victory in the theater. ${ }^{25}$ Herbert Henry Asquith’s The Genesis

\footnotetext{
${ }^{20}$ H.C.G. Matthew The Gladstone Diaries with Cabinet Minutes and Ministerial Correspondence Volume X January 1881 to June 1883 (Oxford: Clarendon Press, 1990) and Agatha Ramm ed., Political Correspondence of Mr. Gladstone and Lord Granville 1876-1886, Volume 1 1870-1882 (Oxford: Clarendon Press, 1963).

${ }^{21}$ Gladstone to Lord Ripon 9-6-1882 in Matthew, 327.

${ }^{22}$ William Gladstone, Midlothian Speeches 1879 (New York: Humanities Press, 1971).

${ }^{23}$ Lord Cromer, Modern Egypt 2 vols. (New York: The Macmillan Company, 1916).

${ }^{24}$ Lord Edward Cecil, The Leisure of an Egyptian Official (London: Hodder and Staughton, 1921).

${ }^{25}$ T.E. Lawrence, Seven Pillars of Wisdom: A Triumph (Garden City, N.Y.: Doubleday, Doran, \& Co., inc., 1936) and T.E. Lawrence, Revolt in the Desert (New York: George H.Doran Company, 1927).
} 
of War contains a summary of the events leading up to World War I as well as the text of the Anglo-French Agreement of 1904 and the Anglo-Russian Agreement of $1907 .{ }^{26}$ The particularly useful source on World War II was Winston Churchill's The Second World $\underline{\text { War, }}$ in particular Finest Hour and $\underline{\text { Hinge of Fate. }} .{ }^{27}$ No primary source on World War II in North Africa is greater than Viscount Montgomery's The Memoirs of Field Marshall the Viscount Montgomery of Alamein KG, which allows the battle and events leading up to and after the battle to be described by the hero of Alamein. ${ }^{28}$

The final phase of attachment benefited from a multitude of primary sources. The most useful was Anthony Eden's Full Circle: the Memoirs of Anthony Eden. ${ }^{29}$ More than any other man, Eden was involved in and blamed for the disaster at Suez and oversaw what many believe to be the death knell of the British Empire. In his memoirs, Eden attempts to justify his actions during the Suez Crisis and portray them as successful. A different viewpoint is provided by Randolph Churchill's The Rise and Fall of Sir Anthony Eden which amounts to a harangue against Eden's handling of the Suez Crisis and his entire career. ${ }^{30}$ The biographies of Harold Macmillan provided an invaluable assistance and most notably Tides of Fortune 1945-55 and Riding the Storm 1956-59, which depict Macmillan's role in the Suez Crisis and response to the economic crisis that

\footnotetext{
${ }^{26}$ Herbert Henry Asquith, The Genesis of War (London: Cassell \& Company Ltd., 1923).

${ }^{27}$ Winston Churchill, The Second World War Volume 2 Their Finest Hour (Boston: Houghton Mifflin Co., 1949) and Winston Churchill The Second World War Volume 4 the Hinge of Fate (Boston: Houghton Mifflin Co., 1950).

${ }^{28}$ Viscount Montgomery, The Memoirs of Field Marshall, the Viscount Montgomery of Alamein, KG (New York: the World Publishing Company, 1958).

${ }^{29}$ Anthony Eden, Full Circle: the Memoirs of Anthony Eden (London: Cassel \& Co. Ltd., 1960).

${ }^{30}$ Randolph Churchill, The Rise and Fall of Sir Anthony Eden (London: MacGibbon \& Kee, 1959).
} 
befell Britain during the time of the Suez debacle. ${ }^{31}$ Additionally, the latter volume gives details of Macmillan's own Government and the process of decolonization. Evelyn Shuckburgh’s Descent to Suez: Foreign Office Diaries 1951- 1956 provides a day by day account of the pre-nationalization dealings of Britain in the Middle East as well as the memoirs of Eden’s former secretary and Foreign Office Under Secretary dealing with Middle Eastern Affairs. ${ }^{32}$ Shuckburgh was quite close to Eden, in an important diplomatic position during the Suez Crisis, and provides an invaluable work with the publication of his diary. Selwyn Lloyd's Suez 1956: A Personal Account includes the memoirs of Eden's Foreign Secretary and the man, along with Eden, given much of the blame for the failure of the Suez expedition. ${ }^{33}$ Edward Heath's The Course of My Life: My Autobiography provides a first hand account of the Suez Conspiracy and the Parliamentary reaction to the collusion. ${ }^{34}$ Robert Murphy's A Diplomat Among Warriors and Chester Cooper's The Lion's Last Roar provide the American perspective on the crisis and the British decision to intervene. ${ }^{35}$ Mohamed Heikal's Cutting the Lion's Tail:

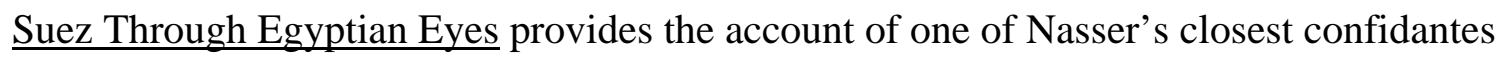

\footnotetext{
${ }^{31}$ Harold Macmillan, Tides of Fortune, 1945-1955 (New York: Harper \& Row, 1969) and Harold Macmillan, Riding the Storm 1956-1959 (New York: Harper \& Row, 1971).

${ }^{32}$ Evelyn Shuckburgh, Descent to Suez: Foreign Office Diaries 1951-56: From Churchill's Last Government to the Suez Crisis Under His Hand picked Successor Anthony Eden (New York: W.W. Norton \& Company, 1986).

${ }^{33}$ Selwyn Lloyd, Suez 1956: A Personal Account (New York: Mayflower Books, 1978).

${ }^{34}$ Edward Heath, The Course of My Life: My Autobiography (London: Hodder \& Staughton, 1998).

${ }^{35}$ Chester Cooper, The Lion's Last Roar: Suez 1956 (New York: Simon \& Schuster, 1978) and Robert Murphy, A Diplomat Among Warriors (Garden City, N.J.: Doubleday, 1964).
} 
and a glimpse into both the mind of Nasser and the Egyptian view of the event. ${ }^{36}$ The most useful account on events in Jordan during this time is John Bagot Glubb’s A Soldier with the Arabs which not only demonstrates the importance of the Arab Legion and Britain to Transjordan, but also provides a description of Glubb’s dismissal, which served to generate Eden's hatred of Nasser. ${ }^{37}$

It would be impossible to master every detail of British imperial history and thus certain general texts have been used to supplement the non-Suez related imperial history. While primary sources form the basis of this study, numerous secondary sources were also consulted. Lawrence James’ Rise and Fall of the British Empire provided a solid overview of the world of the British Empire and also in a condensed version that allowed for easy digestion as did Bernard Porter's The Lion’s Share: a Short History of British Imperialism 1850-1970..$^{38}$ Also, Robert Robinson and John Gallagher's Africa and the Victorians: the Official Mind of Imperialism yielded not only an excellent commentary on British involvement in Egypt and the events at Fashoda, but also provided a description of both the moral and economic theories of imperialism. ${ }^{39}$ Ornamentalism by David Cannadine, while not a general history, gave a most invaluable contribution to this

\footnotetext{
${ }^{36}$ Muhammad Heikal, Cutting the Lion's Tail: the Suez Through Egyptian Eyes (New York: Arbor House, 1987).

${ }^{37}$ John Glubb, A Soldier with the Arabs ( New York: Harper \& Brothers Publishers, 1957).

${ }^{38}$ Lawrence James, The Rise and Fall of the British Empire (New York: St. Martin's Press, 1994) and Bernard Porter, The Lion's Share: A Short History of British Imperialism 1850-1970 (London: Longman Group, 1975).

${ }^{39}$ Robert Robinson and John Gallagher, Africa and the Victorians: the Official Mind of Imperialism (London: MacMillan \& Co. LTD., 1965).
} 
work through its theory. ${ }^{40}$ Cannadine holds that the attachment to the empire was generated by imposition of the British class system and the creation of parallel social systems, which yielded particular attachment to the colonies, dominions, and mandates. Furthering this theory is the work of A.P. Thornton in The Imperial Idea and its Enemies and its seminal contribution to scholarship on British Imperial thought. ${ }^{41}$ The most useful aspect of this work was Thornton's assertion that the Middle East was the last place that the British could feel imperial and provides a rationale for the British reluctance to withdraw from the region.

With a topic such as this, there is also a need to understand Indian history and pre 1875 Anglo-Egyptian relations and British Foreign Policy. ${ }^{42}$ In terms of pre-canal history and British involvement in Egypt, the best available source is Edward Ingram's The British Empire as a World Power, which addresses both the repercussions of the invasion of 1800, the steps and policy leading to the invasion, and new view of Egypt as the key to India, but also develops a conclusion of an empire over Europe approach to policy and a brief section on the expansion of the Indian empire under Wellesley. ${ }^{43}$ Additionally, Britain in the Middle East by Sarah Searight provides traveler's accounts of Englishmen in the Middle East. Sir Reader Bullard's Britain and the Middle East from the Earliest Times to 1956 furthers Searight’s work in tracing early British contact with

\footnotetext{
${ }^{40}$ David Cannadine, Ornamentalism (Oxford: Oxford University Press, 2001).

${ }^{41}$ A.P. Thornton, The Imperial Idea and Its Enemies (London: the Macmillan Co., 1970).

${ }^{42}$ The most useful sources on India were the following: Sarvepalli Gopal, British Policy in India 1858-1905 (Cambridge: Cambridge University Press, 1965), John McLeod, A History of India (London: Greenwood Press, 2001), and Thomas Metcalf, Ideologies of the Raj(Cambridge: Cambridge University Press, 1991). ${ }^{43}$ Edward Ingram, The British Empire as a World Power (London: Frank Cass, 2001).
} 
the Middle East, but surpasses Searight by its attention to detail and discussion of British policy up until the Suez Crisis. ${ }^{44}$ Several general histories of Egypt and the Ottoman Empire during this period were consulted. ${ }^{45}$ The best work on the topic is John Marlowe's A History of Modern Egypt and Anglo-Egyptian Relations 1800-1956 which combines the development of post Mameluke Egypt with an appraisal of the diplomatic history of British-Egyptian relations. ${ }^{46}$

As has already been noted, the first phase was heavily reliant upon Hansard's and other primary sources, but also made use of some secondary sources. The phase also is heavy on sources dealing with Gladstone and Disraeli. In reference to Disraeli, one must always begin with Robert Blake’s Disraeli, by far the best biography ever written about Disraeli and an exhaustive account of the life of the mercurial prime minister. ${ }^{47}$ Also, Edgar Feuchtwanger's Disraeli was a useful source, though more compacted than the exhaustive work of Blake. ${ }^{48}$ For details on the 1882 invasion and the penultimate battle of Tel -el Kebir in Egypt see Byron Farwell’s Queen Victoria’s Little Wars. ${ }^{49}$

\footnotetext{
${ }^{44}$ Sir Reader Bullard, Britain and the Middle East from Earliest Times to 1963 (London: Hutchinson University Library, 1964) and Sarah Searight, The British in the Middle East (New York: Atheneum, 1970).

${ }^{45}$ See William Cleveland, A History of the Modern Middle East (Boulder, CO.: Westview Press, 1994), Justin McCarthy, The Ottoman Turks An Introductory History to 1923 (London: Longman, 1997), and Efraim and Inari Karsh, Empires of the Sand: the Struggle for Mastery in the Middle East 1789-1923 Cambridge, MA.: Harvard University Press, 1999).

46 John Marlowe, A History of Modern Egypt and Anglo-Egyptian Relations 1800-1956 (Hamden, CT.: Archon Books, 1965).

${ }^{47}$ Robert Blake, Disraeli (New York: St. Martin’s Press, 1967).

${ }^{48}$ Edward Feuchtwanger, Disraeli (London: Arnold Publishers, 2000).

${ }^{49}$ Byron Farwell, Queen Victoria’s Little Wars (New York: W.W. Norton Company, 1972).
} 
The second phase encompasses three main events: World War I, interwar diplomacy, and World War II. For works discussing the Suez Canal in World War I see the already mentioned works of Marlowe, Hallberg, and Schonfield. The naval race and the deterioration of Anglo-German relations are expertly retold in Robert Massie’s Dreadnought: Britain, Germany, and the Coming of the Great War. ${ }^{50}$ The work focuses on the naval advancements in the pre-war era, but is also useful in its address of all aspects of Anglo-German relations. In terms of general histories of World War I, John Keegan's The First World War was a useful source and provided a coherent summary of the Mediterranean theater of World War I and addresses action in the Suez Canal area, the Arab revolt, Gallipoli, and Salonika. ${ }^{51}$ B.H. Liddell Hart’s War in Outline 1914-1918 also proved very useful. ${ }^{52}$ Finally, the topic of coping with trench warfare and the actual experience of World War I are described in the legendary The Great War and Modern Memory by Paul Fussell. ${ }^{53}$ For a general work on the interwar diplomacy, European Diplomacy between the Two Wars 1919-1939, edited by Hans Gatzke, is particularly helpful, most notably the sections on the Anglo-German Naval Agreement, Hoare-Laval Pact, and the new interpretation of the Munich crisis. ${ }^{54}$ Robert H Ferrell's Peace in Their Time was useful for its discussion of the Washington Naval Conference. ${ }^{55}$ Ian Nish’s

\footnotetext{
${ }^{50}$ Robert Massie, Dreadnought: Britain, Germany, and the Coming of the Great War (New York: Ballantine Books, 1991).

${ }^{51}$ John Keegan, The First World War (London: Alfred A. Knopf Inc., 1999).

${ }^{52}$ B.H. Liddell Hart, The War in Outline 1914-1918 (New York: Modern Library, 1936).

${ }^{53}$ Paul Fussell, The Great War and Modern Memory (Oxford: Oxford University Press, 1975).

${ }^{54}$ Hans Gatzke, ed., European Diplomacy between Two Wars 1919-1939 (Chicago: Quadrangle Books, 1972).

${ }^{55}$ Robert H. Ferrell, Peace in Their Time (New York: W.W. Norton \& Company, 1953).
} 
Japanese Foreign Policy in the Interwar Period provided information on the termination of the Anglo-Japanese alliance. ${ }^{56}$ For secondary information on the Second World War, see John Keegan's The Second World War. ${ }^{57}$

In terms of the Middle East in World War I and the subsequent establishment of the mandate system, there are several noteworthy works. The story of Allenby and his role in the Middle East is expertly told in Brian Gardner's Allenby of Arabia: Lawrence's General, which is based on the traveling lecture tour of the postwar era. ${ }^{58}$ Another noteworthy achievement of the previously mentioned works of Lawrence was to generate a further Romantic attachment to the region, which is also apparent in the works of Rudyard Kipling, most notably Kim which portrayed the romantic land and happenings beyond the Suez Canal. ${ }^{59}$ E.M. Forster's A Passage to India, while not specifically commenting upon the Middle East, does attach a certain romantic aura to the canal. ${ }^{60}$ Bruce Westrate provides an indispensable study of the Arab Bureau and the struggle between London, Cairo, and Delhi for dominance in shaping the policy in the Middle East in his The Arab Bureau: British Policy in the Middle East 1916-1920. ${ }^{61}$ The end result of the lands seized from the Ottoman Empire and the struggle between the India Office and Foreign Office is found in Briton Cooper Busch's Britain, India, and the

\footnotetext{
${ }^{56}$ Ian Nish, Japanese Foreign Policy in the Interwar Period (Westport, CT.: Praeger Press, 2002).

${ }^{57}$ John Keegan, The Second World War (New York: Viking Press, 1996).

${ }^{58}$ Brian Gardner, Allenby of Arabia: Lawrence's General (New York: Coward-McCann, 1965).

${ }^{59}$ Rudyard Kipling, Kim (New York: Doubleday, 1925).

${ }^{60}$ E.M. Forster, A Passage to India (New York: Modern Library, 1924).

${ }^{61}$ Bruce Westrate, The Arab Bureau: British Policy in the Middle East 1916-1920 (University Park, PA.: Pennsylvania State University Press, 1992).
} 
Arabs, 1914-1921, which outlines the intentions of the India Office to claim Mesopotamia as part of their imperial sphere. ${ }^{62}$ The Sykes-Picot Agreement and the ramifications of this agreement are detailed in David Fromkin's A Peace to End All Peace: The Fall of the Ottoman Empire and the Creation of the Modern Middle East. ${ }^{63}$ Also, the establishment of the British protectorate over Egypt and the accompanying text can be found in Hurewitz. Additional aid was rendered by Byron Farwell's The Great War in Africa which depicts the struggle for colonies in Africa during World War I, which served to tie down British troops in the pursuit of Lettow-Voorbeck. ${ }^{64}$

The interwar period is best exemplified by the gravitation between two topics: British Foreign and Defense Policy and the British Empire in the Middle East. Interwar policy in Egypt can be best found by consulting the works of Marlowe and any of the general histories on the Suez Canal, most notably Schonfield. The most important possessions were Egypt, Iraq, and Transjordan. These lands were under direct British control for a period of time and after their independence were dominated by Britain, earning the title informal empire. The quintessential work on this portion of British Imperial history is Elizabeth Monroe’s Britain’s Moment in the Middle East, 1914$1971{ }^{65}$ Daniel Silverfarb’s Britain's Informal Empire in the Middle East: A Case Study

\footnotetext{
${ }^{62}$ Briton Cooper Busch, Britain, India, and the Arabs, 1914-1921 (Berkeley, CA.: University of California Press, 1971).

${ }^{63}$ David Fromkin, A Peace to End All Peace: the Fall of the Ottoman Empire and the Creation of the Modern Middle East (New York: Avon, 1994).

${ }^{64}$ Byron Farwell, The Great War in Africa (New York: W.W. Norton \& Company, 1986).

${ }^{65}$ Elizabeth Monroe, Britain's Moment in the Middle East 1914-1971 (Baltimore, MD.: Johns Hopkins University Press, 1981).
} 
of Iraq 1929-1941 provides a glimpse of the strategic importance of Iraq and the process of Iraqi independence through the 1930 Anglo-Iraqi Treaty, in addition to the Iraqi insurgency/ attack on the Royal Air Force (RAF) base at Habbayynia. ${ }^{66}$ The best work on British administered Iraq is Peter Sluglett's Britain in Iraq 1914-1932 which provides a detailed study of the creation of the state of Iraq and the numerous issues dealt with by the British. ${ }^{67}$ In terms of Transjordan, Mary Wilson's King Abdullah, Britain, and the Making of Jordan provides a useful survey of the state building process and happenings in Transjordan after the First World War. ${ }^{68}$ Palestine is an overwhelming topic and it is not the point of this paper to enter into the quagmire that is Palestinian history. Several histories of Israel, Palestine, and the Palestine Mandate were consulted for this thesis. ${ }^{69}$

The interwar period is of vital importance for the imperial attachment to the Suez Canal, particularly in the multitude of shifts in importance of the canal in British policy. Two areas of research in terms of this topic exist dealing with the Mediterranean strategy of the British Empire during the interwar period and the military policy of the British Empire in the post-war era. In terms of British military policy, the decline and neglect of

\footnotetext{
${ }^{66}$ Daniel Silverfarb, Britain’s Informal Empire in the Middle East; A Case Study of Iraq 1929-1941 (New York: Oxford University Press, 1986).

${ }^{67}$ Peter Sluglett, Britain in Iraq 1914-1932 (London: Ithaca Press, 1976).

${ }^{68}$ Mary Wilson, King Abdullah, Britain, and the Making of Jordan (Cambridge: Cambridge University Press, 1987).

${ }^{69}$ For the information on Palestine see the following sources Benny Morris, Righteous Victims: A Brief History of the Zionist-Arab Conflict 1881-2001 (New York: Vintage Books, 1999), Yezid Sayigh Armed Struggle and the Search for State (Oxford: Oxford University Press, 1999), two works by Michael Cohen Palestine and the Great Powers 1945-48 (Princeton, N.J.: Princeton University Press, 1982) and Palestine, Retreat from Mandate: the Making of British Policy 1936-1945 (New York: Holmes \& Meier, 1978). In addition, the autobiographies of early Israeli statesmen provide insight into the topic, most notably Yitzhak Rabin, The Rabin Memoirs (Boston: Little, Brown, \& Company, 1979) and Abba Eban, Abba Eban: an Autobiography (New York: Random House, 1977).
} 
the army is described in Brian Bond's British Military Policy Between the Two World Wars. $^{70}$ The work describes the disdain for militarism in the postwar era in Britain and the implementation of the Cardwell system and the Ten Year Rule by the British military, which showcases not only the embracing of the spirit of Locarno and Kellogg-Briand Pact, but also shows the apathy described by Fussell. The Great Powers in the Middle East 1919-1939 demonstrates the waning paramountcy of Britain in the Middle East after World War I and the gradual intrusion and competition of Italy and Germany in the region, in addition to discussing the initial American forays into the region. ${ }^{71}$ The Suez Canal underwent a diminution in importance in the interwar era and this is best illustrated by Lawrence Pratt’s East of Malta, West of Suez: Britain's Mediterranean Crisis 19361939 and Steven Morewood's "Protecting the Jugular Vein of Empire: The Suez Canal in British Defense Strategy 1919-1941.”72 Both works address the Mediterranean crisis and the British decision to focus on a Far Eastern Strategy based out of Singapore in addition to holding the Mediterranean. Also, Pratt discusses the Abyssinian crisis in depth and the sense of British weakness where they felt unable to compete with the Italians in war. Morewood and Pratt both convey the difficulty facing Britain and the possibility of a three front war, and the gradual shift back to a "Mediterranean First” strategy. These issues are furthered by Martin Kolinsky’s Britain’s War in the Middle East: Strategy and

\footnotetext{
${ }^{70}$ Brian Bond, British Military Policy Between the Two World Wars (Oxford: Clarendon Press, 1980). ${ }^{71}$ Uriel Dann, ed., The Great Powers in the Middle East, 1919-1939 (New York: Holmes \& Meier, 1988). 72 Steven Morewood, "Protecting the Jugular Vein of Empire; the Suez Canal in British Defense Strategy 1919-1941,” in War \& Society Vol. 10, No.1 (May 1992) 81-107 and Lawrence Pratt, East of Malta, West of Suez: Britain’s Mediterranean Crisis 1936-1939 (Cambridge: Cambridge University Press, 1975).
} 
Diplomacy 1936-1942 which discusses the origination of the doctrine of self-sufficiency for Egyptian defense and the drastic policy shift between the 1937 Imperial Conference favoring a Far Eastern defense strategy and the 1939 St. James Conference focusing on Mediterranean defense. ${ }^{73}$

The description of World War II in the Middle East draws from the work of Keegan on the topic and is bolstered by Martins Gilbert's definitive biography Winston Churchill, in particular volumes six and seven Finest Hour and The Road to Victory. ${ }^{74}$ Another useful work is Roy Jenkins Churchill: A Biography. ${ }^{75}$ The imperative victory at El Alamein is expertly detailed in John Bierman and Colin Smith’s The Battle of Alamein: Turning Point of the War which provides every conceivable detail of the battle and the North African campaign. ${ }^{76}$ The failure of the Singapore strategy and the doomed naval demonstration is described in Christopher Bell's “The Singapore Strategy and the Deterrence of Japan: Winston Churchill, the Admiralty, and the Dispatch of Force Z."77 The failure of an Atlantic Alliance cooperative strategy in the Far East is described in

\footnotetext{
${ }^{73}$ Martin Kolinsky, Britain's War in the Middle East: Strategy and Diplomacy 1936-1942 (New York: St. Martin’s Press, 1999).

${ }^{74}$ Martin Gilbert, Winston Churchill, Vol. 6, 1939-1941, Finest Hour (Boston: Houghton Mifflin, 1983) and Martin Gilbert, Winston Churchill, Vol. 7, 1941-1945, the Road to Victory (Boston: Houghton Mifflin, 1986).

${ }^{75}$ Roy Jenkins, Churchill: A Biography (New York: Farrar, Straus, and Giroux, 2001).

${ }^{76}$ John Bierman and Colin Smith, The Battle of Alamein: Turning Point of World War II (New York: Viking Press, 2001).

${ }^{77}$ Christopher Bell, "The Singapore Strategy and the Deterrence of Japan: Winston Churchill, the Admiralty, and the Dispatch of Force Z," in English Historical Review Vol. 116, No. 467 (2001):604-634.
} 
Nicholas Clifford’s “Britain, America, and the Far East 1937-1940: a Failure in Cooperation.”78

The third phase from 1945 to 1956 deals with three main topics: decolonization, Britain in the Cold War, and the Suez Crisis. The most useful source is William Roger Louis’ The British Empire in the Middle East 1945-1951: Arab Nationalism, the United $\underline{\text { States, and Postwar Imperialism. }}{ }^{79}$ This superb work highlights the challenges facing Britain in the postwar era from within the Middle East and the need to re-define the role of the empire in the new world order. The work also provides an excellent survey of the policy of the Attlee Government towards the Middle East and their dealing with the Palestine issue and the rise of Egyptian Nationalism. Further useful works on the British Empire in the Middle East and decolonization in general are D. George Boyce’s $\underline{\text { Decolonization and the British Empire 1775-1997 and John Darwin’s Britain and }}$ Decolonization: the Retreat from Empire in the Postwar World. ${ }^{80}$ The ultimate demise of the British Empire and the withdrawal from Aden, Sudan, and the Persian Gulf is described in Glen Balfour-Paul's The End of Empire in the Middle East: Britain's Relinquishment of Power in her last Three Dependencies. ${ }^{81}$ The struggle to find a postwar role and define her world power status was a constant worry for Britain in the

\footnotetext{
${ }^{78}$ Nicholas Clifford, “Britain, America, and the Far East 1937-1941: A Failure in Cooperation,” in Journal of British Studies Vol. 3, No.1 (1963):137-154.

${ }^{79}$ William Roger Louis, The British Empire in the Middle East 1945-51: Arab Nationalism, the U.S. and Postwar Imperialism (Oxford: Clarendon Press, 1984).

${ }^{80}$ D. George Boyce, Decolonization and the British Empire, 1775-1997 (London: Macmillan Press, LTD., 1999) and John Darwin, Britain and Decolonization: the Retreat from Empire in the Postwar World (N.Y., St. Martin's Press, 1988).

${ }^{81}$ Glen Balfour-Paul, End of Empire in the Middle East: Britain’s Relinquishment of Power in Her Last Three Dependencies (Cambridge: Cambridge University Press, 1991).
} 
postwar world. There was gravitation between establishing itself as a superpower on par with the United State and Union of Soviet Socialist Republics or to be powerful through the Atlantic Alliance. This dilemma had some bearing in the decision to stay in the Middle East and to stand guard against any Soviet incursion. This attitude and struggle for definition are described in the aforementioned Louis work, Glubb’s Britain and the Arabs: A Study of Fifty Years 1908-1958, Ingram's British Empire as a World Power, and C.J. Bartlett's British Foreign Policy in the Twentieth Century. ${ }^{82}$ A useful work on the Attlee Government's foreign policy is Kenneth Morgan's Labour in Power 1945$\underline{1951}^{83}$

There are several secondary sources on the leaders and events of the Suez Crisis. A supplement to Eden’s own biography is Robert Rhodes James’ Anthony Eden: A Biography, which is a thorough account of the life of Eden; Eden's own work only covers his career in the second Churchill Government, his Ministry, and the Suez Crisis. ${ }^{84}$ Peter Hahn’s The U.S., Great Britain and Egypt 1945-56: Strategy and Diplomacy in the Early Cold War describes the Suez Crisis in terms of the Cold War and the British action as driving the Egyptians into the arms of the USSR, thus scuttling American efforts to prevent a Soviet incursion into the Middle East. ${ }^{85}$ Suez 1956: the Crisis and Its

\footnotetext{
${ }^{82}$ C.J. Bartlett, British Foreign Policy in the Twentieth Century (New York: St. Martin's Press, 1989) and John Glubb, Britain and the Arabs: A Study of Fifty Years 1908-1958 (London: Hodder \& Staughton, 1959).

${ }^{83}$ Kenneth Morgan, Labour in Power 1945-1951 (Oxford: Clarendon Press, 1984).

${ }^{84}$ Robert Rhodes James, Anthony Eden: A Biography (New York: McGraw-Hill Book Company, 1986)

${ }^{85}$ Peter Hahn, The U.S., Great Britain, and Egypt 1945-56:Strategy and Diplomacy in the Early Cold War (Chapel Hill, N.C.:, 1991).
} 
Consequences edited by William Roger Louis and Roger Owen provides a beneficial set of articles analyzing the crisis from every aspect and arguing that economics ultimately doomed the British to failure. ${ }^{86}$ Leon Epstein’s British Politics During the Suez Crisis is intended as a work of political science and ultimately derides the British system of government and the inevitable disappearance of a two party British political system. ${ }^{87}$ However, the work is indispensable for its use of Suez as a case study and provision of newspaper polls over the crisis. Epstein also suggests that the role of the Suez as a focal point for British victories in the Middle East during both World Wars made it impossible to dispense with the canal and describes the Suez Group of the Conservative Party which seized on this issue as recourse for their desire for an old empire. The references to Suez as semblant to Munich are to be found in Macmillan, Eden, and Lloyd. A personal reflection on the Suez Crisis and its discussion in a family setting is described in Cannadine. A very interesting article, Martin Francis' “Tears, Tantrums, and Bared Teeth: the Emotional Economy of Three Prime Ministers, 1951-1963,” suggests the emphasis of stoic calm and lack of emotion as a public persona as undertaken by Churchill, Eden, and Macmillan. ${ }^{88}$ This need to "hold it in" resorted in the breakdowns and outbursts of Eden during the Suez Crisis. The issue of the media and newspaper coverage of the Suez Crisis is addressed in the following two articles: Ralph Negrin's

\footnotetext{
${ }^{86}$ William Roger Louis and Roger Owen, Suez 1956: Crisis and Consequences (Oxford: Clarendon Press, 1989).

${ }^{87}$ Leon Epstein, British Politics in the Suez Crisis (Urbana, IL.: University of Illinois Press, 1964).

${ }^{88}$ Martin Francis, "Tears, Tantrums, and Bared Teeth: the Emotional Economy of Three Conservative Prime Ministers, 1951-1963 in Journal of British Studies Vol. 41, No. 3 (July 2002), 354-387.
} 
“The Press and the Suez Crisis” and Guillaume Parmentier's “The British Press in the Suez Crisis. „89

${ }^{89}$ Ralph Negrin, "The Press and the Suez Crisis: a Myth Re-examined” in The Historical Journal Vol. 25, No. 4, (December 1982), 975-984, and Guillaume Parmentier, "The British Press in the Suez Crisis" in The Historical Journal Vol. 23, No. 2 (June 1980) 435-445. 


\section{Chapter II}

\section{Disraeli’s Coup and Gladstone’s Reluctant Intervention: Imperial Attachment to the Canal 1875-1914}

In 1875 Queen Victoria termed the Suez Canal share purchase a great event in modern politics and the purchase itself was a triumph for Disraeli. ${ }^{1}$ The canal formed a vital component of British policy and cemented the ultimate association of Britain with Egypt. The rationale for this purchase predated the canal itself and two main events shaped this relationship: the French invasion of 1800 and the Great Revolt of 1857 . The French invasion caused great fear in Great Britain. This invasion demonstrated that Egypt represented an Achilles’ heel of the British Empire and threatened India. The Great Revolt showed the tenuous nature of the British hold on India under the East India Company and the need to secure the crown jewel of the empire. While the bulk of this section focuses on British policy and its attachment towards the canal from 1875 to 1914 , the two pre-canal events are discussed in detail. Upon completion of this overview, the main events of British policy towards the canal in the first phase of attachment will be explored: the share purchase, dual control, the 1882 invasion, the Baghdadbahn, and the pre World War I diplomatic state of affairs in the Mediterranean world.

\footnotetext{
1 Disraeli to Lady Bradford 11-26-1875, in Marquis of Zetland ed., Letters of Disraeli to Lady Chesterfield and Lady Bradford 2 vols. (New York: D. Appleton \& Co., 1929), 465.
} 
In 1798, the importance of Egypt to the British became evident due to the French invasion of Egypt. France invaded Egypt as a way to crush England, rob her of commerce, and cripple the empire. ${ }^{2}$ Napoleon remarked, "the time is not far distant when we shall feel that in order to really destroy England, it is necessary for us to possess Egypt.”3 After it became known that British troops would be required to subdue the French force in Egypt, Britain dispatched her troops to Egypt. This action demonstrated that when faced with the preservation of Indian security or Continental influence, the British Government opted for defense of India. After the eventual expulsion of the French force in 1802, historian Edward Ingram believes the British maintained their presence at Malta not only to show their desire to stay in the region, but also to separate Europe from the empire as much as possible. ${ }^{4}$ By maintaining the base at Malta, the British hoped to control the routes to the empire and prevent European matters from resulting in attacks on her imperial possessions overseas. The French invasion demonstrated that Egypt could be a matter of consequence to European affairs. ${ }^{5}$ At this point, the Suez land bridge and the preservation of communications with India became the most important element in British strategic planning in Asia, long before the canal was even built. ${ }^{6}$ In the 1830 s, the British used steamships and a regular steam and land route between Suez and Alexandria to

\footnotetext{
${ }^{2}$ Charles Hallberg The Suez Canal: Its History and Diplomatic Importance (New York: Columbia University Press, 1931), 61.

${ }^{3}$ Ibid.

${ }^{4}$ Edward Ingram, The British Empire as a World Power (London: Frank Cass, 2001), 295.

${ }^{5}$ Hugh Schonfield, The Suez Canal in Peace and War 1869-1969 (Coral Gables, FL.: University of Miami Press, 1969), 13.

${ }^{6}$ Ingram, 269.
} 
improve communications with India. ${ }^{7}$ The new Suez route shortened the passage from England to India to forty days, compared with five months round the Cape. ${ }^{8}$ Britain did not want other European states to control this vital route. The French invasion provided the impetus for Britain to begin entrenchment in the Eastern Mediterranean and led Tsar Nicholas I to remark to the French Ambassador to the Russian Empire that:

The English have their eyes on Egypt. The country is necessary to them on account of the new line of communication they seek to open with India. They are establishing themselves in the Red Sea and the Persian Gulf. ${ }^{9}$

In the mid nineteenth century, the British became locked in a territorial rivalry with the Russians over interests in Central Asia, the Ottoman Empire, and the Far East. ${ }^{10}$ Britain decided upon a forward defense strategy for the Middle East and wanted to use trade and sea power to secure defense goals in the region and to use the Ottoman Empire as a buffer against both Russia and France. ${ }^{11}$ Britain also expected any challenge to their influence in the Middle East to come from sea and concentrated on a naval defense strategy. ${ }^{12}$ While the invasion led to an interest in the region for the safety of India, events in India led to the region becoming of utter importance.

The British intervened in Egypt and remained at Malta to guard India from her European rivals. But events in India in 1857 further necessitated the British attachment to

\footnotetext{
${ }^{7}$ John Marlowe, A History of Modern Egypt and Anglo-Egyptian Relations 1800-1956 (Hamden, CT.: Archon Books, 1965), 43.

${ }^{8}$ Ibid., 42.

${ }^{9}$ Schonfield, 14.

${ }^{10}$ Ingram, 55.

${ }^{11}$ Ibid., 155-8.

${ }^{12}$ Ibid., 126-8.
} 
Egypt and the later canal. The Great Revolt presented the gravest challenge to British control of India and resulted in the direct imposition of crown control. The popular view considers the revolt to have arisen out of the rumor that cartridges issued to Indian troops were greased with animal fat, a practice repugnant to the Muslim and Hindu soldiers of the Indian army. In actuality, taxes, denial of Foreign Service positions, religious reasons, future opportunities, and a desire to reclaim the conquests of the East India Company sparked the mutiny. ${ }^{13}$ The revolt began in late May 1857 and the mutineers captured Delhi and reinstalled the Mughal dynasty as rulers of India. ${ }^{14}$ The revolt spread. Sepoys turned on their officers. Rebels besieged British forces and civilians in the cities of Agra, Cawnpore, and Lucknow. British reinforcements as well as reinforcements from garrisons throughout the eastern empire arrived by the end of July. ${ }^{15}$ By 1858 the British crushed the revolt, abolished the Mughal dynasty, and instituted direct crown control. ${ }^{16}$ Britain needed India for troops and India also supplied raw materials, foodstuffs, and manufactured goods to the Home Islands, in addition to being a source of money and a market. ${ }^{17}$ India made Britain a world power and the Great Revolt demonstrated the dangers that could arise in India.

Prior to the Suez Canal construction, the British concluded that Egypt provided the key to the gateway to India. The prospect of an enemy controlling the Egyptian land

\footnotetext{
${ }^{13}$ John McLeod, A History of India (London: Greenwood Press, 2002), 82.

${ }^{14}$ Lawrence James, The Rise and Fall of the British Empire (New York: St. Martin's Press, 1994), 226.

${ }^{15}$ Ibid., 228.

${ }^{16}$ McLeod, 84.

${ }^{17}$ Ibid.
} 
route constituted a viable threat to India. Additionally, the Great Revolt proved to Britain that it was necessary to have a quick route to India for the sake of dispatching reinforcements in times of trouble. When the canal was completed in 1869, the immediate beneficiary was Britain, who constituted the majority of the shipping through the canal. The British had already exhibited a willingness to sacrifice Continental influence for imperial safety and the canal proved a vital conduit for trade to her eastern empire. Once the canal became vital for trade to India, it became vital for Britain to control the canal. ${ }^{18}$ The French invasion and the Great Revolt demonstrated to France what Britain would do to protect India. The opening of the canal would further test the British commitment to Indian defense.

The opening of the Suez Canal in 1869 and the resulting British trade through the canal laid the foundation for the imperial attachment to the canal. The British had strategic and commercial interests in the canal. The idea of a canal was initially regarded as a French military weapon in Britain and events on the Continent were not going well for the empire. ${ }^{19}$ Imperial pride underwent a renewal with the election of Benjamin Disraeli as Prime Minister in 1874. He was widely regarded as the "defender of empire” and concerned with ships, commerce, and colonies. ${ }^{20}$ Disraeli purchased the canal shares, sent Indian troops to Malta to sway the Russians on the Treaty of San Stefano, and took

\footnotetext{
${ }^{18}$ Hallberg, 236.

${ }^{19}$ D.A. Farnie, East and West of the Suez: The Suez Canal in History 1854-1956 (Oxford: Clarendon Press, 1969), 4.

${ }^{20}$ Ibid., 269.
} 
other actions for the sake of defending the sea lanes and India. ${ }^{21}$ The interesting decision was the canal share purchase in 1875 since a Colonial Office official had referred to the Cape Route as the center of the empire in $1871 .^{22}$ While an obvious reason was the security of India, trade was also a vital concern. By the end of his Ministry, Disraeli had laid the foundation for the imperial attachment to the canal.

The opening of the canal and the years leading up to the purchase saw an overwhelming British gain from the canal. In 1870, 486 ships carrying 436,609 net tons passed through the canal of which 314 ships and 289,234 tons were British. ${ }^{23}$ In 1871 , out of 761,467 net tons of canal traffic 546,453 were British. ${ }^{24}$ In 1872 1,160,744 tons passed through the canal; 854,037 British. ${ }^{25}$ In 1873, 1,367,768 tons went through the canal; 994,331 British. ${ }^{26}$ The following year 1,631,650 tons passed through the canal with 1,200,022 destined for or from Britain. ${ }^{27}$ The year of the share purchase Britain accounted for $1,476,775$ tons of the canal's annual total of $2,009,984 .^{28}$ In terms of tonnage by flag, Britain accounted for the majority of the transit with France having a tiny fraction of the total British shipping. ${ }^{29}$ Roughly $4 / 5$ of Suez traffic was British and the abundance of British trade passing through the canal was one of the main reasons for

${ }^{21}$ Ibid., and Robert Blake, Disraeli (New York: St. Martin’s Press, 1967), 643.

${ }^{22}$ Robert Robinson and John Gallagher, Africa and the Victorians: the Official Mind of Imperialism (London: MacMillan \& Co. LTD., 1965), 59.

${ }^{23}$ Schonfield, 204.

${ }^{24}$ Ibid.

${ }^{25}$ Ibid.

${ }^{26}$ Ibid.

${ }^{27}$ Ibid.

${ }^{28}$ Ibid.

${ }^{29}$ Ibid., 206-7. 
the share purchase. ${ }^{30}$ The security of India was also a reason since the canal had nearly halved the distance from India to England. ${ }^{31}$ In case of any disturbances similar to the Great Revolt, the time for dispatching reinforcements was quicker and allowed a quicker suppression of threats to the crown jewel of the empire. Finally and perhaps most importantly, the value of the canal to Britain for both commerce and security had become apparent in the early 1870s, but the canal was still controlled by a French dominated company and Egypt by the Ottoman Empire. The Treaty of London of 1841 provided for a hereditary governorship (khedive) of Egypt which owed tribute to the Ottoman Government. ${ }^{32}$ While Egypt was semi-autonomous, the Khedive owed allegiance to the Ottoman Sultan. ${ }^{33}$

The financial success of the Suez Canal was in doubt in 1871 and the Egyptian investment in the canal appeared to be more of a burden than a benefit. The Egyptian government had paid eight million pounds for fifteen percent of the net profits of the canal. ${ }^{34}$ By 1871, the value of canal shares had dropped from Fr.500 to Fr.208 and the Egyptian government was struggling financially. ${ }^{35}$ Khedive Ismail, who had lived lavishly and spent lavishly during the Egyptian cotton boom, sought a buyer for his shares of the canal. Ismail accumulated an average debt of seven million pounds per year

\footnotetext{
${ }^{30}$ Blake, 581.

${ }^{31}$ For example the Cape journey from Calcutta to Liverpool was 11,600 miles, but through Suez it was only 7,900 miles taken from Donald Neff, Warriors at Suez: Eisenhower Takes America into the Middle East (New York: Linden Press, 1981), 12-13.

${ }^{32}$ William Cleveland, A History of the Modern Middle East (Boulder, CO.: Westview Press, 1994), 72-3.

${ }^{33}$ Ibid.

${ }^{34}$ Marlowe, 72.

${ }^{35}$ Ibid., 73.
} 
and became unable to make payments in $1875 .{ }^{36} \mathrm{He}$ arranged a purchase option to be offered to a French banker and for the Disraeli government to hear of this offer. ${ }^{37}$ Disraeli heard of this offer and protested to the French Government that Britain would object to the canal being wholly controlled by the French. The French Government was reeling from the crushing defeat of the 1870 Franco-Prussian War and allowed the option to lapse. Thus roughly forty percent of the canal shares were up for sale and Disraeli faced both a dilemma and an opportunity.

While the French had bypassed the option to gain the entire controlling interest in the canal no guarantee existed that the opportunity might not be seized by another British opponent. Additionally the value of the canal to trade and Indian security was well known. Disraeli was determined that no country should control the Khedive's shares and believed that the canal was vital to the British Empire. ${ }^{38}$ After the French rejection of the Egyptian offer, General Stanton the British Consul-General in Egypt informed the Egyptian government that “Her Majesty’s Government are disposed to purchase the shares if satisfactory terms can be arranged." ${ }^{39}$ The Egyptians offered the shares to Britain for the sum of four million pounds sterling and the offer was conveyed to the Disraeli government on November 23, 1875, with an addendum that an answer was required by November 25. On November 24, Lord Derby wired Stanton to close on the offer. The government funded the purchase through a banking house founded by the

\footnotetext{
${ }^{36}$ Schonfield, 47.

${ }^{37}$ Marlowe, 72.

${ }^{38}$ Schonfield, 48.

${ }^{39}$ Ibid., 47.
} 
Rothschilds and the purchase was approved while Parliament was not in session. ${ }^{40}$

Despite the sidestepping of Parliament, the Disraeli Government had acquired nearly half of the canal shares.

Disraeli was exceptionally proud of himself and conveyed his self congratulation in a letter to Lady Bradford:

After a fortnight of most uneasing labor and anxiety for between ourselves and ourselves only I may be egotistical in this matter I have purchased for England the Khedive of Egypt's interest in the Suez Canal ... had this not been done the whole of the canal could have been French. ${ }^{41}$

Disraeli believed he had scored a tremendous victory for the empire by preventing the French from controlling the canal. He furthered his self acclaim by conveying Queen Victoria's sentiments about the purchase. Noting the Queen was happy about the purchase, she also told Disraeli the purchase was "a great event in modern politics.”42 The purchase had been a triumph for Disraeli. The purchase was a calculated step to strengthen the empire and gave England a financial footing in Egypt thereby allowing her to prevent any other country from obtaining exclusive control over the canal. ${ }^{43}$ The purchase also led the press to view the canal as an indispensable highway of empire and the British public cheered the purchase. ${ }^{44}$ The canal was a success for Disraeli even though the purchase placed the British Government in the awkward position of being a

\footnotetext{
${ }^{40}$ Ibid., 48.

${ }^{41}$ Disraeli to Lady Bradford 11-26-1875 in Zetland, 460.

${ }^{42}$ Disraeli to Lady Bradford 11-26-1875 in Ibid., 465.

${ }^{43}$ Edward Feuchtwanger, Disraeli (London: Arnold Publishers, 2000), 180 and A.P. Thornton The Imperial Idea and Its Enemies (London: MacMillan \& Co. LTD., 1958), 58.

${ }^{44}$ Farnie, 239.
} 
minority shareholder in a French Company. ${ }^{45}$ In spite of this awkwardness, the canal purchase was a triumph and as historian D.A. Farnie stated the issue, "Egypt became almost an appendage to the necessary stepping stone to India and increased in value as a dependent line of empire. ${ }^{46}$ The Cheltenham Free Press conveyed the importance of the purchase by printing “Egypt is as necessary to England as Alsace Lorraine is to Germany."47 Disraeli had secured the vital link to the empire and the canal became a foremost interest for the British. Yet Disraeli still had a hurdle to clear when Parliament reconvened in February.

In February 1876 the House of Commons met to debate the share purchase. They sanctioned the purchase, but not before the government was called to task for the impetuous nature of the purchase without Commons consultation. Chancellor of the Exchequer Northcote began the debate by providing a short history of the canal and the benefit to England:

Now this great enterprise is one from which its first inception has attracted the attention of this country ... The canal has been made, has been opened, and has been proven a great advantage to England. ${ }^{48}$

The Chancellor criticized the initial British disinvolvement from the canal and professed that the benefit of the canal had deemed that this mighty enterprise should be controlled by Britain. Despite the language of destiny, the root message was the shares were British

\footnotetext{
${ }^{45}$ Paul Knaplund, Gladstone’s Foreign Policy (New York: Harper \& Bactus, 1935), 135.

${ }^{46}$ Farnie, 239.

${ }^{47}$ Cheltenham Free Press 4 December 1876 cited in Farnie, 239.

48 Lord Northcote 2-10-1876 in Hansard's Parliamentary Debates 1876 Vol. 227 ( London: Cornelius Books, 1876 and New York Kraus Reprint Company, 1971), 264-70.
} 
and now so was the canal. He furthered this assertion by touting the benefit to India and reading a statement from the India Office, in which the canal's influence on British relations with India was stated as two-fold:

Its influence on our relations with India is twofold- administration and commercial. The administration has greatly benefited by the additional facilities afforded for the transport of troops to and from India. ${ }^{49}$

The economic benefit of the canal was well known to the MPs in Commons and Northcote stressed the imperial benefit and how the canal aided the administration and protection of India. During the remainder of his speech, Northcote stated that "it is of great importance that we should make the best provisions we can for securing uninterrupted passage to India and our Eastern possessions. ${ }^{50}$ His most telling statement was,

It is destined to be an eternal possession of the human race; and I am sure be a proud satisfaction to us if England fulfills her proper part in securing and consolidating this great enterprise. ${ }^{51}$

Northcote cited four reasons for the purchase. The first was the obvious commercial benefit stemming from the trade with India and the British holdings in Australasia. The second was the security of the Indian Empire and benefit to holding the eastern possessions of the empire. Both of these reasons were apparent to the members of Commons. However, the other two reasons were more tenuous. The notion of destiny

\footnotetext{
${ }^{49}$ Chancellor of Exchequer reading India Office report 2-10-1876 in Ibid., 274.

${ }^{50}$ Northcote 2-10-1876 in Ibid., 274.

${ }^{51}$ Ibid.,. 281.
} 
was unexpected and attempted to provide Britain with a non-political reason for purchasing the shares. The last reason, the benefit to humanity, wedged the purchase of the shares into the greater imperial mission, presumably to make the share purchase tolerable to the Liberals. It would only make sense that the British Empire, being the greatest power on earth, controlled the canal. While some flowery embellishment on Northcote’s part existed, Disraeli was more practical:

I have always and do now recommend it to the country as a political transaction and one which I believe is calculated to the strengthen the empire ... we are obtaining a great hold and interest in this important position, because they believe that it secures to us a highway to our Indian empire and other dependences. ${ }^{52}$

Disraeli provided the clearest rationale for the purchase, which was alluded to in his first letter to Lady Bradford: empire. The calls of destiny and imperial mission served to invest the canal with a high place in the imperial mind and to also give the purchase a more moral/elevated reason for the purchase. Yet as soon as the canal became vital for trade, it became vital for England to control it. ${ }^{53}$ The safety of India and the commercial benefit of trade strengthened the empire. As Disraeli later demonstrated, the canal could also be used to deploy the powerful Indian army into Europe if necessary, as was done at Malta in 1878. Disraeli informed Lady Bradford of the threat of French control of the canal, but the French could just as much close the canal as they could close the Straits of

\footnotetext{
${ }^{52}$ Disraeli 2-21-1876 in Ibid. , 662.

${ }^{53}$ Hallberg, 246.
} 
Gibraltar. ${ }^{54}$ If either were done, the French would be displaced by the powerful British Navy and a landing force composed of both the British Army and Indian Army. In addition, France was still reeling from her defeat in 1870 and was presumably unable to risk such an endeavor. The belief soon arose that if there was no canal there would be no India. ${ }^{55}$ Britain had become the canal's biggest client by 1875 and the economic benefit and benefit for controlling India were tied to the canal. The purchase also served to keep a British voice in the management of the French dominated Suez Canal Company. ${ }^{56}$ Thus Disraeli purchased the canal shares to strengthen the empire. Because of the purchase the canal "was disassociated from Egypt in the English mind."57

In terms of British political thought after the initial euphoria, the canal suffered a relative diminution in stature in relation to other concerns. Disraeli noted in 1876 that Constantinople was the key to India not Egypt and the Suez Canal. ${ }^{58}$ The Russo-Turkish war of 1877 and the possible collapse of the Ottoman Empire created the possibility of Russian domination of the Eastern Mediterranean. This threat would persist until World War I. If Russia controlled the Eastern Mediterranean and the Straits, the strategic value of the canal would be lost and the eastern portion of the empire threatened. In addition, the First Report of the Royal Commission on Colonial Defense noted:

the general result of these inquiries is that the security of the Suez route might under certain contingencies become very precarious and the risk attendant on

\footnotetext{
${ }^{54}$ Marlowe, 75.

${ }^{55}$ Farnie, 455.

${ }^{56}$ Robinson and Gallagher, 83.

${ }^{57}$ Farnie, 485.

${ }^{58}$ Robinson and Gallagher, 82.
} 
sending commercial ships through it so great as practically to preclude it use in which case the long sea route would be the only one available. ${ }^{59}$

The Suez Canal was subject to local disturbances and was not surrounded by British dominated territory as the Cape Route. Additionally, the British had no desire to get involved in Egyptian affairs not related to the canal. Disraeli supported the Ottomans as a way to buttress any Russian incursion into the Middle East and Egypt was under the suzerainty of the Ottoman Empire. While the canal had been dissociated from Egypt in the British mind, the next decade proved the opposite and interwove the canal interests of Britain with the affairs of the tumultuous state of Egypt.

By 1882, events served to bring the British into Egyptian affairs and resulted in their permanent presence on Egyptian soil. The Egyptian debt began to expand in 1876. In that year her foreign loan debt rose to sixty eight million pounds, her internal loans were fourteen and a half million pounds with a fourteen million pound floating debt. ${ }^{60}$ The debt arose from the Westernizing policies of Said and Ismail, which saw great increases in the amount of rail and telegraph lines, canals, and cultivable land. ${ }^{61}$ Egypt was going bankrupt and Europe was losing its investment in Egypt. While the improvements were great, the Egyptian Government financed these projects through European loans and the improvements were nullified by the expenditures. In particular, Ismail attempted to improve the Egyptian infrastructure along European lines and was

\footnotetext{
${ }^{59}$ Ibid., 60 .

${ }^{60}$ Marlowe, 91.

${ }^{61}$ Ibid., 90-1.
} 
buoyed by the Egyptian cotton boom during the American Civil War. Unfortunately, the end of the American Civil War ended the Egyptian cotton boom. The British share purchase temporarily stemmed this trend, but in 1876 the growing insolvency of the Egyptian government led European investors to dispatch the Cave Mission. Stephen Cave, a British MP, was sent to Egypt in 1876 to investigate the financial situation. He reported that Egypt was in a critical financial state. ${ }^{62}$ The situation became critical in 1878 and the French communicated to the British Foreign Minister Lord Derby that if the two governments did not act together the matter was in danger of slipping out of their control. ${ }^{63}$ The British and French governments appointed a joint Commission of Enquiry and when Ismail formed an international cabinet with both the French and British Commissioners as members of the cabinet, the action shocked the Commission. Ismail took steps to remove the influence of the commissioners and felt their inclusion had pacified the two European governments. The flouting of European advice and negligent financial practices led the British and French to push for Ismail's abdication. Despite numerous calls for his willing abdication, Ismail determined to stay in power. The AngloFrench turned to the Ottoman Sultan who delivered a firman of deposition to Ismail on June 25, 1879. ${ }^{64}$ The Ottoman Government appointed Ismail’s son Tawfiq khedive. Britain pressured France to refrain from influencing Egyptian affairs after the deposition, but the French maintained a presence and the Egyptians appointed controllers. These

\footnotetext{
${ }^{62}$ Ibid., 93.

${ }^{63}$ Ibid., 96.

${ }^{64}$ Marlowe, 102.
} 
controllers, the British controller being Evelyn Baring later Lord Cromer, were to be present at Cabinet meetings, demand information, give advice, and report to their diplomatic representatives if the Egyptian Government failed to heed their advice. ${ }^{65}$ The foreign investors acting through their governments later established an international commission to evaluate the debt and it resulted in the Law of Liquidation calling for roughly half of Egypt's annual income of eighty million five hundred thousand pounds to be earmarked for debt repayment. ${ }^{66}$ It became the duty of the controllers to administer Egyptian finances to repay the debt and those two controllers became the bankers of the Egyptian Government. The debts of Egypt had grown to such an extent to cause the deposition of a Khedive in 1879 and British and French controllers installed to oversee finances. The establishment of Dual Control not only demonstrated the power of the British and French in regard to influencing Egypt, but it also laid the groundwork for the 1881-1882 Arabi revolt. Dual Control resembled Anglo-French suzerainty over Egypt and led to resentment in the country over foreign dominance. ${ }^{67}$

While the British oversaw the finances of Egypt, the canal still held a paramount interest. In 1877, Lord Derby had noted that "maintenance of uninterrupted communication of the canal is in our view a British interest, one of the highest importance, and one which we feel it is our duty not to neglect." ${ }^{\text {68 }}$ He later stated that the

\footnotetext{
${ }^{65}$ Ibid., 105.

${ }^{66}$ Ibid., 107.

${ }^{67}$ Ibid., 99.

${ }^{68}$ Earl of Derby 5-4-1877 in Hansard's Parliamentary Debates 1877 Vol. 227 (London: Cornelius Books, 1877 and New York Kraus Reprint Company, 1971), 315.
} 
canal is "too grave and delicate a matter to be dealt with in an offhand manner." ${ }^{69}$ Lord Derby made these statements in response to the Russo-Turkish War and the threat to Egypt, but Egypt was never threatened. The importance is that the canal, despite the findings of the Colonial Defense Report and Disraeli’s Constantinople statement, was still vitally important to Britain and her empire. British policy remained to control and protect the canal and to avoid Egyptian entanglements, but the British had been drawn into by the issue of Dual Control. Lord Cromer noted that the British policy in 1879 was to not possess Egypt, but also to make sure no other country possessed it. ${ }^{70}$ The detriment was that while the Suez Canal was still important and the Dual Control did not represent actual control, the presence of foreign domination fomented subversion in Egypt and left Britain with the choice of having to determine how much the canal was worth to its empire.

The British maintained the policy of using the Ottoman Empire to buttress any threat to the region, particularly by Russia, but this changed in 1880 with the election of William Gladstone and the Liberals to Government. ${ }^{71}$ Gladstone gained office by seizing upon the atrocities in Bulgaria as a cause of interest to the British electorate. Gladstone was also anti-Turk and accused Disraeli of annexing Egypt. ${ }^{72}$ Gladstone was less likely to favor the pro-Constantinople strategy of Disraeli and opposed more territorial acquisition

\footnotetext{
${ }^{69}$ Earl of Derby 5-7-1877 in Ibid., 361.

${ }^{70}$ Lord Cromer, Modern Egypt Vol. 1 (New York: MacMillan Co., 1916), 91.

${ }^{71}$ Robert Harrison, Road to Suez: Gladstone and the Egyptian Crisis of 1882 ( Ph.D. diss., University of Southern California, 1987), 5.

${ }^{72}$ William Gladstone, Midlothian Speeches 1879 (New York: Humanities Press, 1971), see all speeches contained in this volume for anti-Turk views, $1^{\text {st }}$ Midlothian for accusation.
} 
believing a more moral foreign policy was the best pursuit of the British government. He understood the canal as preserving the maintenance and security of empire and had announced this view in $1859 .{ }^{73}$ However, the new government was less likely to further British involvement in Egypt and desired avoiding any foreign entanglements such as Disraeli had in Zululand and Afghanistan. This shift away from direct action and militancy was passing and the Gladstone Government drew up contingency plans for an invasion of Egypt in the wake of the French seizure of Tunis in $1881 .{ }^{74}$ The ready acceptance of intervention by Gladstone’s Cabinet and Gladstone’s ultimate acceptance show the importance of the canal to British defense policy. It appears that while Gladstone would not indulge in the multitude of wars that Disraeli did, he would act to defend vital interests and India. The Gladstone Ministry became involved in Egypt in 1882 and this involvement proved the extreme importance of the Suez Canal to Britain since a pacifist government was willing to invade Egypt.

The troubles began with the forced abdication of Ismail and his replacement by the more pliable Tawfiq. ${ }^{75}$ With Tawfiq's accession the controllers exerted almost total control over Egypt and the Law of Liquidation called for heavy taxes in Egypt, with half the revenue going to the debt. ${ }^{76}$ What developed from an Egyptian point of view was the Europeans had entered Egyptian politics, overthrew/forced out the legitimate Khedive, and laid exorbitant taxes on the Egyptian population. Several bases of opposition arose,

\footnotetext{
${ }^{73}$ Harrison, 51.

${ }^{74}$ Ibid , 6.

${ }^{75}$ Marlowe, 106.

${ }^{76}$ Ibid.
} 
most importantly Constitutionalism and discord among the native Egyptian officers of the army. ${ }^{77}$ Ismail had been able to quash this discontent, but the combination of Tawfiq, who was not as strong as Ismail, and the proliferation of European influence exacerbated the discontent and allowed it to manifest itself in the political realm. The Egyptian army led the way. Ismail was in the process of raising the size of the army to sixty thousand, but the Dual Control and Tawfiq insisted on a reduction to eighteen thousand and many officers lost their careers. ${ }^{78}$ Ahmad Arabi emerged as the officers’ leader. He proved instrumental in forcing Tawfiq to appoint one of their candidates Minister of War and invited the Constitutionalists to form a government. ${ }^{79}$ The success of the officers against Tawfiq demonstrated the disfavor afforded Tawfiq in Egypt and their actions revealed him to be a puppet of the British and the French, essentially only the efforts of the British and French governments allowed Tawfiq to remain in power. The officers' movement was profoundly anti-foreign targeting the old Turco-Circassian elite of the Egyptian army and the Europeans. The Turco-Circassian elite dated to the times of Mohamad Ali and controlled the army, preventing native Egyptians from attaining command positions. These non-Egyptian elites were the first targets of the officer's movement. The British faced a possible insurgency and missed a chance for pacification when the French Government of Gambetta forced the Gladstone Ministry to deny the Constitutionalist

\footnotetext{
${ }^{77}$ Ibid., 112-13.

${ }^{78}$ Ibid., 115.

${ }^{79}$ Ibid.
} 
demand to vote on the budget and have input on Egyptian finances. ${ }^{80}$ By this rejection, the Europeans drove the Constitutionalist Government of Egypt closer to the Army and set the stage for further anti-foreign threats to Tawfiq's authority.

The disturbance and challenge to Khedival authority began to worry the Gladstone Government. In October 1881, Gladstone wrote to Lord Granville that the Ottomans should handle the revolt. Under this plan, the only European involvement would be the dispatch of a joint squadron. ${ }^{81}$ Despite his anti-Turkish policy and the weakening of the Anglo-Ottoman alliance, Gladstone was not about to place Britain in a situation necessitating the invasion of Egypt. A need to pacify the nationalists and restore the authority of Tawfiq existed, but it was not the responsibility of Britain. On January 4, 1882, the Governments of Britain and France issued a Joint Note calling for Khedival support, protection of the bondholders, all of which served to threaten the Nationalists. ${ }^{82}$ The Joint Note stressed the British and French support for Tawfiq and implied AngloFrench action or intervention if Tawfiq's power was threatened. The threat of intervention is conveyed in the following:

I have accordingly instructed you to declare to the Khedive that the British and French Governments consider the maintenance of His Highness on the throne, on the terms laid down in the Sultan's firman and officially recognized by the two Governments, as alone able to guarantee, for the present and future, the good order and development of general prosperity in Egypt in which France and Great Britain are equally

\footnotetext{
${ }^{80}$ Ibid., 116.

${ }^{81}$ Gladstone to Granville 9-13-1881 and 10-9-1881 in Agatha Ramm ed., Political Correspondence of Mr. Gladstone and Lord Granville 1876-1886 Volume 1 1870-1882 (Oxford: Clarendon Press, 1963) , 67 and 291.

${ }^{82}$ Harrison, 75.
} 
interested. The two Governments, being closely associated in their resolve to guard, by their united efforts, against all causes of complication, internal or external, which might menace the order of things established in Egypt, do not doubt the assurance publicly given of their fixed intention in this respect will tend to avert the dangers to which the Government of the Khedive might be exposed and which would certainly find England and France united to oppose them. ${ }^{83}$

The Egyptians reacted swiftly and the Chamber of Notables began to fall in line with the army and called for budget voting rights and an increase in the size of the army. The Chamber of Notables sided with the army after the issue of the Joint Note and the threat of foreign intervention in the governance of Egypt. On February 3, the Egyptian Government resigned and a new government formed with Arabi as Minister of War. ${ }^{84}$ With Arabi in office and the government at his behest, the controllers could not control the finances. The British and French Governments believed intervention was necessary to protect the lives and property of their citizens in Egypt and sought Ottoman assistance. ${ }^{85}$ When the Ottomans decided against intervention, the British and French agreed to send naval squadrons to Alexandria to protect their subjects and with the fleet's arrival the trouble escalated. ${ }^{86}$ The presence of the fleet was intended to dissuade attacks on European property.

Any chance for a peaceful settlement without British intervention had been lost with the Joint Note and the arrival of the Anglo-French squadron. The new government

\footnotetext{
${ }^{83}$ Marlowe, 118.

${ }^{84}$ Ibid., 119.

${ }^{85}$ Marlowe, 121.

${ }^{86}$ Harrison, 77 and Marlowe, 120-4.
} 
that included Arabi became convinced that it was at risk, but it also had grown powerful enough to nullify Khedival authority and eliminate the Dual Control. The British squadron had orders to protect their subjects while the French instructed their fleet to merely give moral support to the Khedive. ${ }^{87}$ On June 10, anti-foreign riots broke out in Alexandria killing fifty non-Egyptians. The crisis escalated beyond repair and at the beginning of July the Egyptians constructed coastal fortifications and re-enforced the garrison in Alexandria. Admiral Seymour received instructions from the Cabinet on July 5, 1882 that in the event of war a warning should be given and the Alexandria fortifications destroyed. ${ }^{88}$ On July 6, Seymour warned British subjects to leave Egypt. The stage was set for Seymour to issue an ultimatum to raze the fortifications. On July 5, Gladstone instructed First Lord of the Admiralty Lord Northbrook to inform ships using the canal what was occurring, thus attempting to preserve the safety and neutrality of the canal. ${ }^{89}$ Admiral Seymour issued an ultimatum for the construction of coastal fortifications to be halted on July 9 since the forts posed a danger to the British fleet. When no reply came, he shelled Alexandria and destroyed the forts on July 11 . The shelling led to anarchy in Egypt and the British feared that the canal was threatened. On July 14 Gladstone wrote to Chancellor of the Duchy of Lancaster, John Bright, that Arabi

\footnotetext{
${ }^{87}$ Marlowe, 122.

${ }^{88}$ Gladstone 7-5-1882 in H.C.G. Matthew ed., The Gladstone Diaries with Cabinet Minutes and Prime Minister's Correspondence, Volume X January 1881 to June 1883 (Oxford: Clarendon Press, 1990), 291.

${ }^{89}$ Gladstone to Lord Northbrook 7-5-1882 in Matthew, 292-3.
} 
had brought the revolt upon himself. ${ }^{90}$ British forces occupied Alexandria on July 24 and anarchy swept Egypt endangering the canal.

Gladstone and his cabinet approved the dispatch of the army to Egypt in a July 20 meeting and the intervention began. ${ }^{91}$ Gladstone was not intervening simply for the safety of the bondholders, but to re-establish order and for the sake of imperial, Indian, and maritime interests. ${ }^{92}$ The Indian army had been put on alert on June 20 for possible action in the Suez area. ${ }^{93}$ Sir Garnet Wolseley commanded the military expedition that landed at the canal. His force was comprised of 35,000 British troops and 6,000 Indian troops. ${ }^{94}$ The canal had been endangered by the revolt and the Khedive authorized the British troops to seize Isthmian points that were necessary to safeguard the canal..$^{95}$ The father of the canal, Ferdinand de Lesseps feared British control of his creation and telegraphed Arabi:

The English shall never enter the Canal, never. Make no attempt to intercept my Canal. I am there. Not a single English soldier shall disembark without being accompanied by a French soldier. I answer for everything. ${ }^{96}$

Arabi responded by conveying his thanks to de Lesseps, but insisting that the defense of Egypt required the destruction of the canal. ${ }^{97}$ By August the British controlled the canal

\footnotetext{
${ }^{90}$ Gladstone to John Bright 7-14-1882 in Matthew, 298.

${ }^{91}$ Cabinet Minutes 7-20-1882 in Matthew, 300.

${ }^{92}$ Harrison, 102-105.

${ }^{93}$ Ibid., 144.

${ }^{94}$ Ibid.

${ }^{95}$ Schonfield, 50.

${ }^{96}$ Cited in Schonfield, 50.

${ }^{97}$ Ibid.
} 
and the British army destroyed the forces of Arabi on September 13 at the battle of Tel el-Kebir. ${ }^{98}$ As a result, the British controlled Egypt and exiled Arabi to Sri Lanka. The canal was preserved and Egypt stabilized, but what was the real cause for the intervention?

Historian Charles Hallberg noted, "it was the canal that furnished the pretext for intervening in Egypt and it was because of the canal that British troops remained."99 The supposed reasons of restoring Khedival authority and the Alexandria fortifications presumably formed viable reasons for the intervention, but this was not the case. The forts were a concocted threat at best and were little likely to do any serious damage to the British fleet; in fact, British guns caused most of the damage to the city of Alexandria. ${ }^{100}$ Britain feared that the Arabi revolt could spark a similar revolt among their Muslim subjects. Further, British troops were already heading towards the canal on June 20, prior to the actual commencement of hostilities. ${ }^{101}$ The British could not gamble with security of the routes to the east. ${ }^{102}$ The downfall of Khedival government was not a likely impetus to force the anti-jingoistic Gladstone Government to intervene. The danger to the canal allowed for Hartington, the Secretary of State for India, and similar minded ministers to seize Cabinet control and protect what they deemed a vital interest. ${ }^{103}$ Britain

\footnotetext{
98 for a full description of all the happenings of the battle of Tel el-Kebir see Byron Farwell, Queen Victoria’s Little Wars (New York: W.W. Norton \& Company, 1972),253-269.

${ }^{99}$ Hallberg, 209.

${ }^{100}$ Harrison, 108 and 157.

${ }^{101}$ Ibid., 109.

102 Robinson and Gallagher, 159.

${ }^{103}$ Ibid., 121.
} 
professed to be acting in the interests of the Concert of Europe, but Britain was more interested in her own security. Gladstone admitted the true reason for the intervention in a letter to Lord Ripon, the Viceroy of India:

Apart from the canal we have no interest in Egypt itself which could warrant intervention in my opinion. But the safety of the canal will not coexist with illegality and military violence in Egypt and I doubt whether Parliament and the nation would have sanctioned, as they almost universally sanctioned, our proceedings except for the canal. ${ }^{104}$

The canal had assumed an importance far exceeding that accompanying the 1875 share purchase. The fact that the Liberal Gladstone Government was willing to intervene in Egypt for no reason other than the canal suggests the British imperial attachment to the canal. Gladstone’s Government viewed the canal as the linchpin of the empire, the stepping stone to India, and a great boon to trade. The fact that the canal was an interest no government would gamble with demonstrated the extent to which the canal had entered the imperial mind. The British viewed the canal as an imperial necessity. The power of the empire came from India and the British ability to protect and defend India. Britain had sent troops to Egypt and professed that they would only stay until order was restored. They stayed until 1956. While the British Government touted their desire to prevent French domination and Muslim insurgencies in other areas of the empire, the truth was that the canal was the driving force behind Gladstone's intervention in Egypt.

${ }^{104}$ Gladstone to Lord Ripon 9-6-1882 in Matthew, 327. 
His actions assured the safety of the canal. As the turn of the century approached, other states pressed Britain on the issue of the canal.

The British occupation of Egypt created several unintended consequences despite the profession that it was a temporary occupation. Cromer believed that the bankruptcy and anarchy in Egypt left intervention the only answer. ${ }^{105}$ However, in a few years he believed that reconstructed Egypt was a brighter jewel in the imperial crown than India. ${ }^{106}$ The occupation yielded two consequences for the canal. First, Europe recognized the British as guardians of the canal. The British believed themselves to be exercising the Egyptian duty of guarding the canal for the simple fact that they were there and the Khedive had invited them to intervene. Additionally, the British occupation led to increased cries for, and a British desire to accommodate, the international status of the canal. Other powers wanted guarantees for the free transit of the canal while at the same time the British wanted to maintain the ability to intervene to protect the canal. Attempts at settling the issue dragged, but in 1888 were settled at Constantinople.

On October 29, 1888, Britain, Germany, Austria-Hungary, Spain, France, Italy, the Netherlands, Russia, and the Ottoman Empire signed the 1888 Constantinople Convention. ${ }^{107}$ The most telling article was Article I which read:

The Suez Maritime Canal shall always be free and open in time of war as in time of peace, to every vessel of commerce or of war, without distinction of flag.

\footnotetext{
${ }^{105}$ Lord Cromer, Modern Egypt Volume I (New York: Macmillan Co., 1916), 320.

${ }^{106}$ Lord Cromer, Modern Egypt Volume II (New York: Macmillan Co., 1916), 256.

${ }^{107}$ Text of 1888 Constantinople Convention found in Schonfield, 185-8.
} 
Consequently, the High Contracting Parties agree not in any way to interfere with the free use of the Canal, in time of war as in time of peace The Canal shall never be subjected to the exercise of the right of blockade. $^{108}$

Article IV reasserted the need for the canal to remain open in war even if the Ottomans were one of the belligerents in the conflict, with this statement, the rightful guardians of the canal could not even use the right of free passage to their advantage. ${ }^{109}$ However, a loophole existed since Article IX called for the government of Egypt to act as charged with the enforcement and execution of the Treaty. ${ }^{110}$ Article IX allowed for the British to have a say in the defense of the canal because of their occupation and because of the power they wielded in Egypt, Britain effectively governed Egypt. By 1890, Egypt was a vital linchpin of British Eastern Mediterranean strategy. ${ }^{111}$ Also, the Ottoman Empire’s continued decay necessitated the presence of Britain in Egypt to check Russian advances and to preserve the path to India. However, other powers took aim at the British position in Egypt.

In addition to the signing of the Constantinople Convention, the granting of the Baghdad rail concession to Germany took place in $1888 .{ }^{112}$ The concession proposed the opening of a railroad from Central Europe as far as Istanbul. ${ }^{113}$ The line was seen as the

\footnotetext{
${ }^{108}$ Article I of the 1888 Constantinople Convention in Schonfield, 185.

${ }^{109}$ Article IV of the 1888 Constantinople Convention in Schonfield , 186.

${ }^{110}$ Article IX of the 1888 Constantinople Convention in Schonfield, 187.

${ }^{111}$ Bernard Porter, The Lion's Share: A Short History of British Imperialism 1850-1990 (London: Longman Group, 1995), 153.

${ }^{112}$ Kenneth Bourne, Foreign Policy of Victorian England (Oxford: Clarendon Press, 1970), 140

113 Schonfield, 61.
} 
first stage of a proposed rail line from Berlin to Baghdad. This concession not only threatened the British hegemony in the Persian Gulf, but it also threatened to circumvent the canal. The overland route potentially made the canal less important and allowed the possible transit of a military force to the borders of Persia. The Germans had asserted that one of the reasons the proposed rail was to aid the Ottomans in reclaiming control over outlying areas and could substantially weaken British dominance of the East and offset the canal. ${ }^{114}$ In Die Baghdadbahn, Paul Rohrbach formulated a clear way to harm the British Empire:

England can be attacked and mortally wounded by land from Europe in one place-Egypt. The loss of Egypt would mean not only the end of her dominion over the Suez Canal and her communications with India and the Far East, but would probably also entail the loss of her possessions in Central and East Africa. The conquest of Egypt by a Mohammadan power, like Turkey, would also imperil England's hold over her sixty million Mohammadan subjects in India ... The stronger Turkey becomes the greater will be the danger for England, if in a German-English war, Turkey should be on the side of Germany. ${ }^{115}$

This followed an earlier surmisal of the importance of the Canal by Bismarck, who said that the canal,

Is like the spinal cord which connects the backbone with the brain. The Canal is the most important factor in shaping British Foreign Policy and its control accounts in no small measure for England's predominant position in world affairs. ${ }^{116}$

\footnotetext{
${ }^{114}$ Ibid., 62.

${ }^{115}$ Ibid., 62-3 and Hallberg, 322-3.

${ }^{116}$ Hallberg, 310.
} 
By the turn of the century, the Germans challenged British world power and Britain found herself without any European allies. The Germans followed a three-fold path entailing the construction of a strong navy, the building up of the Ottoman Empire, and the use of rail to displace the British power emanating from the Suez Canal. These matters came to a head in the 1906 Aqaba incident when a resurgent Ottoman Empire occupied the Sinai Peninsula, an Ottoman holding. The British did not accept Turkish troops so close to the canal, especially since the strengthened German-Ottoman alliance, and sent warships to force the troops to retreat. In this instance, the British undermined the authority of the Sultan in Egypt and had asserted their claim for true control of Egypt. $^{117}$

The Germans and Ottomans were not the only countries which made forays against the British domination of the canal in the late nineteenth century and early twentieth century. France and Russia were particularly upset with the British occupation of Egypt and they felt that the British were supplanting the Ottoman Empire as suzerain of Egypt. ${ }^{118}$ The Italians feared the French threatening Italy from North Africa and sought alliance with Germany and Austria-Hungary in the Triple Alliance. Italy acquired Eritrea, but was repulsed in Abyssinia in $1896 .{ }^{119}$ Despite the defeat in Abyssinia, the Italian acquisition of Eritrea allowed for the Italians to impede Suez traffic if they so chose. These developments placed a German allied Italy on the Red Sea Route to India and

\footnotetext{
${ }^{117}$ Ibid., 313.

${ }^{118}$ Schonfield, 53.

${ }^{119}$ Ibid., 57-8.
} 
created a threat to the security of the sea lane to India. The French gained territory in the Nile Valley at Fashoda, but were evicted. The forces of Kitchener evicted the French force and France was left to ponder the British presence in the Nile Valley. ${ }^{120}$ The British had also expanded their territory into Sudan after the French invasion at Fashoda and the later victory over the Mahdist forces at Omdurman in $1898 .^{121}$ The victory at Omdurman led to the Anglo-Egyptian Condominium over Sudan and the British dominance of the territory for the next half century. The expedition into Sudan and the final territory annexation under the Egyptian flag allowed a buffer for Egypt, but the Italians gained Tripoli and Cyrenaica in their war with the Ottomans in 1912. Sides took shape for a coming conflict. Britain also curried disfavor by denying passage of the canal to Spanish warships in 1898 and acted as a guardian of the canal instead a guardian of the 1888 Convention. $^{122}$

The British viewed the coming conflict as a grave threat to their empire and began to seek alliances. The first alliance was with Japan in $1902 .{ }^{123}$ By 1904 the Germans had risen to equal or greater power than Britain. The Germans had already professed a penchant for a Turkish alliance and the growing naval power of Germany along with the Berlin to Baghdad rail generated fears in Britain. Additionally, the European powers were

\footnotetext{
${ }^{120}$ James, 284-5.

${ }^{121}$ For a full history of the British administration of Sudan see M.W. Daly, Empire on the Nile: The AngloEgyptian Sudan, 1898-1934. (Cambridge: Cambridge University Press, 1986. A Concise account is provided in James, 274-282. For accounts of the attempts to relieve Gordon and the ultimate victory at Omdurman see Farwell, 270-282 and 330-339.

122 Farnie, 402.

${ }^{123}$ Robert Massie, Britain, Germany, and the Coming of the Great War (New York: Ballantine Books, 1991), 339-343.
} 
suspicious of Britain in light of her actions during the Spanish American War and the possibility of the British closing the canal in times of war. However on April 8, 1904, Britain signed an agreement with France that resulted in an alliance between two countries. The genesis of the alliance stemmed from the mutual fears of Germany and amounted to recognition by France of British control over Egypt and a British recognition of French control over Morocco. While the alliance resulted in the end of British isolation and the tacit recognition of her dominance in Egypt, it did require more of Britain in respect to the canal. Article VI of the Agreement stated:

In order to ensure the free passage of the Suez Canal, His Britannic Majesty's Government declare that they adhere to the stipulations of the Treaty of the $29^{\text {th }}$ October 1888 , and that they agree to their being put in force. The Free Passage of the Canal being thus guaranteed the execution of the last sentence of paragraph 1 as well as of paragraph 2 of Article VIII of that Treaty will remain in abeyance. ${ }^{124}$

Article VIII of the 1888 Convention called for the signatories of the Convention to guarantee adherence to the convention and to prevent any developments which interfered with canal navigation, in the event of interference of tribunal of signatory powers would convene to remedy the situation. ${ }^{125}$ Essentially, as long as Britain maintained the free navigation of the canal, no other European power could challenge her dominance by tribunal, as provided by Article VIII of the Convention. ${ }^{126}$ The British had an ally but had forfeited their rights to use the canal as a weapon and instead agreed to abide by the 1888

\footnotetext{
${ }^{124}$ Article VI of the Anglo-French Agreement of 1904 cited in Herbert Henry Asquith, The Genesis of War (London: Cassell \& Company Ltd., 1923), 253-258.

${ }^{125}$ Article VIII of the Constantinople Convention cited in Schonfield, 187.

${ }^{126}$ Ibid.
} 
Convention. The benefit aside from the alliance was that France recognized British gains in Egypt and this advance was shortly afterwards recognized by Russia, Italy, and Austria-Hungary. ${ }^{127}$ In 1907, the British gained further alliances with the signing of the Anglo-Russian Convention settling disagreements in Central Asia, partitioning Persia into zones of influence, and allowing for Britain to be allied with her former enemy. ${ }^{128}$ The Triple Entente, as it was termed, did not become a solid alliance until the outbreak of war; but, for the time being, Britain was safe. ${ }^{129}$ In the years following the 1882 invasion, Britain had suffered threats to her position in Egypt and in the region from France, Italy, the Ottoman Empire, and Germany. The British had firm control over Egypt and by the outbreak of the First World War the canal had even prevented the Ottomans from occupying the adjoining Sinai Peninsula in the 1906 Aqaba incident. The commencement of hostilities in 1914 put the canal in greater danger than it had ever been in 1882.

By the end of the first phase of attachment to the canal, Britain had demonstrated several reasons for its obstinacy on the canal. The canal operated as a great benefit to trade and a quick and viable route for Eastern trade. Additionally, the canal offered the ability to safeguard the route to India and reinforce India itself and other imperial interests. Finally, British policy makers viewed the canal as the linchpin of imperial security. Politicians recognized the importance of the canal for defense and the security of the empire. If the canal was lost or an effective alternative route possessed by an

\footnotetext{
${ }^{127}$ Hallberg, 308.

${ }^{128}$ Asquith, 250-257 and Schonfield, 63.

${ }^{129}$ Asquith, 58.
} 
enemy power, the empire could be at risk and the link between the Home Islands and India severed. The canal became linked with Gibraltar as one of the vital outposts necessary for imperial defense. For all practical purposes, Britain had cemented its relationship with the canal, a relationship that World War I would test. 


\section{Chapter III}

\section{Fighting for the Canal: the Strategic Importance of the Canal in World War I and}

II

By 1914, the Suez Canal had become part of the British Empire. The British had invaded Egypt for the sake of preserving their imperial lifeline and were recognized by other European powers as the guardian of the canal, or at least the de facto guardian. Britain had also gained alliances with Russia and France and appeared to be on good terms with its two traditional rivals. Unfortunately new threats emerged and the German incursions into the Middle East through the rail concession and the Italian acquisition of African colonies placed two hostile powers on either side of the canal. In particular the Italians were a concern to the British since their alliance with Germany and their proximity to the Red Sea enabled them to potentially interfere with canal shipping. Also the Ottoman Empire had grown increasingly weary of the British infringement upon their domains. The British seizure of Egypt and the Sudan drove the Ottomans into alliance with Germany. The repercussions of the Aqaba incident of 1906 portrayed the British as unlikely to respect the authority of the Sublime Porte and caused the Ottoman Government to seek allies. Finally, the British alliance with Russia had rendered a peaceful Anglo-Ottoman coexistence near impossible. When events in Europe came to a 
boil, uncertainty surrounded the canal and each day brought a greater chance of Britain having to fight for the canal.

The hostilities and the chain reaction from Archduke Franz Ferdinand's assassination enveloped Europe in a massive war with Britain, Russia, France, Belgium, and Serbia arrayed against Germany and Austria-Hungary. Since most of these countries possessed overseas colonies, it was only logical that those areas would also become sites of conflict. The Ottoman Empire initially stayed out of the war, but the war forced them to take a side in 1914. On August 2, 1914 the Ottoman Empire concluded a treaty of alliance against Russia with the German Empire and secured a buttress to any Russian territorial aggrandizement. ${ }^{1}$ Two days later the British government purchased two Dreadnought battleships they had been building for the Ottoman Government and left the Ottoman navy severely weakened. ${ }^{2}$ The Germans sailed their Mediterranean squadron into Ottoman waters, hoisted the Ottoman flag, and were thus commissioned part of the Ottoman navy. The Ottomans said the acquisition of the German squadron of a battle cruiser and light cruiser were necessary replacements for the ships detained by the British. ${ }^{3}$ On October 29, the Ottoman navy attacked the Russian ports of Odessa, Sebastopol, Novorossik, and Feodosia, precipitating a Russian declaration of war on the Ottomans on November 1 and a British declaration of war on the Ottoman Empire by

\footnotetext{
${ }^{1}$ John Keegan, The First World War (New York: Vintage Books, 1998), 216.

${ }^{2}$ Ibid.

${ }^{3}$ For a good description of the importance of the Dreadnought battleship and its role both in the AngloGerman Naval Race and the importance of these ships for the Ottoman navy see Robert Massie, Dreadnought: Britain, Germany, and the Coming of the Great War (New York: Ballantine Books, 1991).
} 
November $3 .^{4}$ Sultan Mehmed V declared a holy war, which was permissible due to his status as successor to the Muslim Caliphate, and called upon all Muslim subjects in French, Russian, and British territories to rise against their imperial masters. ${ }^{5}$ The worst fears of the British had come to fruition.

The Ottoman entry into World War I confirmed British fears and placed the route to India in jeopardy. The state of war between Britain and the Ottoman Empire also diverted British forces destined for dispatch to the Western front. The fear of a Muslim insurgency among British forces and in their imperial holdings generated fears of another Great Revolt. The British faced the same dilemma that they faced in 1800, how to defend the Home Islands and India in the face of an enemy. In World War I the canal served as a conduit for troops from the empire as they embarked to aid the Crown in Europe. Early in the war, Winston Churchill of the Admiralty and Minister of War Lord Kitchener discussed the necessity of securing the canal so that Indian troops could be dispatched to the main theater of combat. ${ }^{6}$ Prior to the Ottoman entry into the war, the War Office had envisaged the canal as a necessary holding to convey imperial troops. The Ottoman entry into the war shattered this plan. The Ottoman threat left the canal open to martial activity

\footnotetext{
${ }^{4}$ Keegan., 217.

${ }^{5}$ Ibid.

${ }^{6}$ Martin Gilbert, Winston Churchill Volume III 1914-1916: the Challenge of War (Boston: Houghton Mifflin Co, 1971), 9.
} 
and also opened the possibility of a Muslim insurgency against the British in India and her other eastern possessions. ${ }^{7}$

The canal became a theater of war and a line of defense for Britain, as Hallberg had foreseen. ${ }^{8}$ Anglo-Ottoman hostilities necessitated a change in the administration in Egypt. Despite the ramifications of the Aqaba incident, Egypt was still technically under the suzerainty of the Ottoman Empire and this status left the British in an odd situation. They could not very well defend Egypt against her rightful controllers and thus the British government would have to take steps to remedy the situation. Also, the British perceived the Ottoman war aims to be the taking of Egypt, Western India, Persia, and Suez, all of which would greatly weaken the empire if successful. ${ }^{9}$ The British professed a desire to avoid direct responsibility for Egypt and had acted under the Egyptian flag since 1882, but due to the outbreak of World War I the British had to make a decision to evacuate Egypt or assume direct control.

Prior to the Ottoman declaration of war, the British pressured the Egyptian government to issue a proclamation pointing out that the British occupation rendered Egypt open to attacks from Britain’s enemies and forbade Egyptians from all financial and commercial dealings with Britain's enemies. ${ }^{10}$ The proclamation also urged

\footnotetext{
${ }^{7}$ Shattering quiescence taken from Bruce Westrate, The Arab Bureau: British Policy in the Middle East 1916-1920 (State Park, PA: Pennsylvania State University Press, 1992), 12.

${ }^{8}$ Charles Hallberg, The Suez Canal: Its History and Diplomatic Importance (New York: Columbia University Press, 1931), 295.

${ }^{9}$ Brian Gardner, Allenby of Arabia: Lawrence’s General (New York: Conrad McCann inc., 1965), 216

${ }^{10}$ John Marlowe, A History of Modern Egypt and Anglo-Egyptian Relations 1800-1956 (Hamden, CT.: Archon Books, 1965), 212.
} 
Egyptians to offer any possible aid to Great Britain. ${ }^{11}$ On November 2, 1914, three days before the Ottoman declaration of war, Sir John Maxwell, commander of British forces in Egypt, proclaimed martial law in Egypt and announced the British assumption of Egyptian defense burdens. ${ }^{12}$ The British suspected many Egyptians of harboring proOttoman sympathies, after all Britain was the occupying power. The British had to choose between two ways of incorporating Egypt into the empire: annex Egypt or declare a protectorate. Since the British were in Egypt for the sake of the canal it made little sense to fully incorporate Egypt into the empire, so the protectorate was the most advisable option. Additionally, the Khedive had reaffirmed his loyalty to the Sultan and quickly saw his office abolished when the British declared the protectorate. On December 18-19, 1914, the British government formally announced the protectorate,

His Brittanic Majesty's Secretary of State for Foreign Affairs gives notice that in view of the state of war arising out of the actions of Turkey, Egypt is placed under the protection of his majesty and will henceforth constitute a British Protectorate. The Suzerainty of Turkey is terminated. ${ }^{13}$

The threat to the canal and the benefit it afforded the empire resulted in direct British control over Egypt. The British avoided this assumption for years, but when the Ottomans threatened the canal through invasion, the British took steps to secure their most vital interest in the region. With the canal secured, the British awaited the long feared attack on the canal.

\footnotetext{
${ }^{11}$ Ibid.

12 Ibid., 214.

${ }^{13}$ Establishment of the British Protectorate over Egypt, December 18-18, 1914 in J.C. Hurewitz, Diplomacy in the Near and Middle East. Vol. 2 1914-1956 (New York: Octagon Books, 1972), 5-7.
} 
During World War I, the canal's value to the empire would be tested and the British Government forced to deploy troops to defend the canal. In January of 1915, reports of a twenty thousand man Ottoman force advancing towards the canal thrust the Cairo Office into a panic. ${ }^{14}$ The Cairo Office was the British military and Foreign Office Headquarters in the Middle East. The pending attack was also particularly frightening since many of the occupation troops had been sent to Europe in August to aid the British Expeditionary Force and most regular forces were bound for the Western front. ${ }^{15}$ The War Office adopted a defensive strategy around the canal. The War Office was determined to use any available manpower to defend the canal and forbade any further troop transfers from the Egyptian garrison. ${ }^{16}$ As a benefit, the canal served its role as a staging area for imperial troops destined for the Western front. By January 1915, Territorial troops replacing regular Egyptian garrison forces and troops from India, Australia, and New Zealand on their way to the front, a total of seventy thousand troops, filled Egypt. ${ }^{17}$ On the opposing side, the Ottomans prepared an expeditionary force for dispatch to Egypt to conquer the canal and the commander in chief of this force, Djemal Pasha, was already referring to himself as the "savior of Egypt." ${ }^{\text {18 }}$ The coming attack led the British to station a Lancashire Division, two divisions of Indian infantry, and

\footnotetext{
${ }^{14}$ Hallberg, 326-343.

${ }^{15}$ Hugh Schonfield, The Suez Canal in Peace and War 1869-1969 (Coral Gables, FL.: University of Miami Press, 1969), 70 and Gilbert, 232.

${ }^{16}$ Gilbert, 279, and Briton Cooper Busch, Britain, India, and the Arabs 1914-1919 (Berkeley: University of California Press, 1971), 215.

${ }^{17}$ Keegan, 219.

${ }^{18}$ Schonfield, 70.
} 
Australasian troops along the canal forming a defensive line, as well as Anglo-French naval troops being stationed in the canal. Turkish patrols opened fire on British posts on January 26, 1915 . $^{19}$ The next day, Britain suspended traffic through the canal in preparation for the hostilities. ${ }^{20}$ On February 3, the main Ottoman attack commenced, but was spotted before it began by French aerial reconnaissance. A sandstorm and the British defense repulsed the attack and only one crossing pontoon was even placed in the water. The much ballyhooed attack on the canal was defeated. One more Ottoman assault occurred in June and July of 1916 and was also easily repulsed. ${ }^{21}$ These attacks $^{2}$ confirmed to the British the need to maintain a large British garrison in Egypt. Minister of War Kitchener pronounced the defensive strategy of the canal as doomed to failure and wanted the Ottoman Empire toppled so troops could be sent to the Western Front. ${ }^{22}$ Kitchener believed that keeping a large number of troops in Egypt for defensive purposes was hampering the main war effort in Europe and wanted the Middle Eastern Campaign won as soon as possible. With the repulse of the July Ottoman attack, the canal was safe and the area became a starting point for Lawrence and Allenby. The security of the canal allowed the empire to focus on toppling the Ottoman Empire. In 1917, the Indian army overcame stubborn Ottoman resistance and captured Baghdad. ${ }^{23}$ Allenby took control of the Egyptian Expeditionary Force (EEF) and was determined to break the stalemate that

\footnotetext{
${ }^{19}$ Ibid., 71.

${ }^{20}$ Ibid.

${ }^{21}$ B.H. Liddell Hart, The War in Outline 1914-1918 (New York: Modern Library, 1936), 144-147.

${ }^{22}$ Ibid., and Busch, 116 and 215.

${ }^{23}$ Busch, 10-136.
} 
existed around Gaza. The Ottoman forces along with some German units had established a defensive line around Gaza and used it as a last stand to prevent the British from entering into the heartland of the Ottoman Empire. ${ }^{24}$ Employing a massive artillery bombardment and a gallant cavalry charge by the Australian Light Horse, the EEF overtook Gaza and forced an Ottoman retreat. ${ }^{25}$ Jerusalem fell on December 9 and Allenby, flanked by allied officers, walked into Jerusalem on foot to accept the surrender of the city, as British troops occupied the Holy Lands. ${ }^{26}$ The EEF under Allenby broke Turkish resistance at Megiddo on September 19-21, 1918 and on October 30 the Ottoman Government signed an armistice on the island of Lemnos. ${ }^{27}$ The imagery of the British forces winning a triumphal victory at the site of the first battle and the prophesized site of Armageddon served to enamor the British public. However, Allenby was not the most celebrated of the British commanders. That title fell to T.E. Lawrence, better known as Lawrence of Arabia.

Lawrence was a member of the Arab Bureau and had been sent to the Arabian Peninsula to find a leader to lead the Arabs to victory over the Ottomans. ${ }^{28}$ The Arab Bureau was an organization of Middle East experts organized by the Foreign Office. The Arab Bureau had three critical objectives: "protect the imperial trunk routes to India, mollify anticipated upsurge in Arab demands for self-government through the medium of

\footnotetext{
${ }^{24}$ Keegan, 415.

${ }^{25}$ Gardner, 150.

${ }^{26}$ Ibid., 161-2.

${ }^{27}$ Keegan, 415.

${ }^{28}$ T.E. Lawrence, Revolt in the Desert (Garden City, NY: Garden City Publishing Company, 1927), 15.
} 
British sponsored client state, and obviate the burden of postwar annexation and/or occupation., ${ }^{29}$ The Bureau wanted to raise an Arab insurrection to aid the British attacks on the Ottoman Empire and to siphon off Ottoman troops. The main accomplishment of the Arab Revolt, in which Lawrence played a great role, was the seizure of Aqaba. Lawrence remarked that it was his destiny to take part in the revolt and the conquest of Aqaba. ${ }^{30}$ The rationale for this seizure was Aqaba's presence on the eastern side of the Red Sea and the ability control of Aqaba offered the Ottomans to close the route to Suez. ${ }^{31}$ The revolt consisted of guerrilla raids by Bedouins loyal to the Hashemite clan. Lawrence wanted to make the Arab revolt an engine to his own success, a handmaid to the British Egyptian campaign, and to lead this revolt. ${ }^{32}$ Lawrence and his forces harassed the Ottoman armies as Allenby advanced into Palestine. While Allenby gained victory over the Ottomans, witnessed his troops dispatched to Europe, and awaited Indian reinforcements, Lawrence and Feisal marched on Damascus and proclaimed an Arab government. Feisal was the son of Sharif Husayn of the Hijaz and the leader of Arab army; he would later become king of Iraq. The taking of Damascus was in opposition to the Sykes-Picot Agreement, which was a 1916 agreement dividing the Middle East between Britain and France, and eventually nullified since Syria was promised to France under Sykes-Picot. While the Arab Revolt accomplished little in terms of the overall

\footnotetext{
${ }^{29}$ Bruce Westrate, The Arab Bureau: British Policy in the Middle East 1916-1920 (University Park, PA.: Pennsylvania State University Press, 1992), xiii.

${ }^{30}$ Ibid., 123.

${ }^{31}$ Lawrence, Seven Pillars of Wisdom: a Triumph (New York: Garden City Publishing Company Inc., 1926), 274.

${ }^{32}$ Ibid., 276.
} 
military success of the Middle East Campaign, the adventures of Lawrence served to captivate the British public and make Lawrence a celebrity.

World War I served to further entrench the canal in the imperial mind. First, the canal was the starting point for the only wholly British victory of the war. The victorious British troops began the campaign defending the Suez Canal and started their campaign from the canal area. They won the Middle East campaign with no help from their allies in contrast to the Western Front. Additionally, the victorious forces in this campaign represented all parts of the empire. Britons, Indians, New Zealanders, and Australians defended the canal. The victories of Lawrence, though embellished to great degree by Lawrence himself, and Allenby were launched from the canal. Especially coming on the heels of Gallipoli in 1915-16, the victories restored faith in the British military and were characterized by a more fluid style of war. The cavalry charge at Gaza, the raids of Lawrence, and the biblical imagery of Jerusalem, Megiddo, and Allenby’s marching into Jerusalem on foot, distracted from the harsh trench warfare of the Western front. Finally, the canal had been fought for by British troops and lives had been lost defending the canal against Ottoman attacks. If nothing more, it was now a spoil of war and controlled by the British.

The end of World War I brought murkiness to the position of the Suez Canal in the imperial mind and strategy. Despite its appeal, the priority for the canal route had diminished due to the wartime reliance on the Cape Route. Political Scientist Sir Frederick Maurice stated in a Foreign Affairs article in the aftermath of the war that the 
"canal was not vital to the empire.”33 The canal’s importance shifted from dire importance, and Suez temporarily moved towards being a holding of lesser substance. During the war, the British used the Cape Route for shipping since the canal was subject to mines and German U-Boats roamed the neighboring waters. Beginning in 1915, the Germans concentrated their submarines in the Mediterranean and sank numerous British ships, including fifty six in April $1917 .{ }^{34}$ Also, Continental matters did not hamper the Cape Route and it was less likely to become a combat zone during a European conflict. The British possession of the majority of Southern Africa and the eviction of the Germans from their African colonies added a greater level of safety to the Cape Route. Eventually, the Suez Canal was reopened and convoys allowed for the secure escort of trading ships. ${ }^{35}$ Additionally the relative ease with which the British repelled the attacks on the canal presumably led to some in Britain to disdain the large garrison situated at the canal. The rationale is the disparity between combat near the canal and combat along the Western Front. With few casualties in the Middle East compared to the exorbitant numbers in Europe, many Englishmen questioned the logic of posting such a large garrison in Egypt. Additionally, the supposed mismanagement of strategy fit in with the views of the "lost generation.” While these attitudes occurred at the end of the war, they proved fleeting, similar to the temporary apathy that existed after the initial share purchase by Disraeli.

\footnotetext{
${ }^{33}$ Cited in Hallberg, 348-9.

${ }^{34}$ Hallberg, 346-7.

${ }^{35}$ Ibid.
} 
The conclusion of the war changed the British understanding of the canal and ushered in a renewed period of heightened importance of the canal. The rationale stemmed from two main areas: postwar settlements and Egyptian independence. The postwar settlement allowed for self-determination for many former imperial holdings. But the victors, due to Egypt's protectorate status, denied a seat at the peace talks held at Versailles to the Egyptians. The British obtained the legal right to safeguard the canal through a series of agreements with the Egyptians and the most important being the Turkish forfeiture of the guardianship of the canal to Britain at the Treaty of Sevres. Section IX of the Treaty of Sevres stated

Turkey renounces in favor of Great Britain, the powers conferred upon his Imperial majesty the Sultan by the convention signed at Constantinople on October 21, 1888 relating to the free navigation of the Suez Canal. ${ }^{36}$

The British were officially recognized as the guardian of the canal and given the task of upholding the free navigation of the canal. The British status as guardians of the canal was affirmed in Article 152 of the Treaty of Versailles where

Germany consents in so far as she is concerned to the transfer to His Brittanic Majesty's Government of the powers conferred to His Imperial Majesty the Sultan by the Convention ${ }^{37}$

These sentiments were furthered referred to in peace treaties with Austria (Article 107 of the Treaty of St.Germain), Hungary (Article 91 of the Treaty of Trianon) and Turkey

\footnotetext{
${ }^{36}$ Treaty of Sevres in Hurewitz, 86.

${ }^{37}$ Cited in Schonfield, 73.
} 
(Article 99 of the Treaty of Lausanne). ${ }^{38}$ The Treaty of Lausanne was signed between the allies and the newly proclaimed Turkish republic, which formed after the dissolution of the Ottoman Empire.

Immediately after the end of the First World War, the Egyptians began their move for independence and the renunciation of the British Protectorate, but the British were reluctant to relinquish a strategic holding that was described by Lord Milner as "a nodal point of land, sea, and air communication.”39 The Wafd party led by Saad Zaghul claimed it represented Egypt and desired to form a government, a desire which was not reciprocated by the British Government in Cairo. The Wafd party was formed by members of the landed gentry and legal profession in Egypt and its express goal was the independence of Egypt. ${ }^{40}$ The British arrested Zaghul and his associates on March 8, 1919 and rioting began in Lower Egypt, at one point compelling British troops to open fire. ${ }^{41}$ Disturbances spread and eight British soldiers were murdered by Egyptians in a railway carriage at Deirut Station on March $18 .{ }^{42}$ The British Prime Minister David Lloyd George appointed Allenby High Commissioner in an effort to restore order and maintain the Protectorate. Allenby sympathized with the Egyptian people and ordered the release of the Wafd detainees. Towards the end of 1919, Egyptians murdered more British

\footnotetext{
${ }^{38}$ Schonfield, 74.

${ }^{39}$ Hallberg, 354.

${ }^{40}$ William Cleveland, A History of the Modern Middle East (Boulder, CO.: Westview Press, 1994), 182.

${ }^{41}$ Marlowe, 234.

${ }^{42}$ Ibid.
} 
soldiers and some Egyptians were targeted as well. ${ }^{43}$ As the situation in Egypt worsened, Allenby traveled to London to convince the Cabinet of the need to end the Protectorate. In February 1922, Allenby made the announcement granting Egypt independence for the first time in two thousand years. The Protectorate was abolished and Egypt made independent, but there were some conditions implied in the recognition. The declaration which put an end to the protectorate read as follows:

Whereas His Majesty’s Government, in accordance with their declared intentions, desire forthwith to recognize Egypt as an independent sovereign State; and whereas the relations between his Majesty's Government and Egypt are of vital importance to the British Empire, the following principles are hereby declared

1. The British Protectorate over Egypt is terminated and Egypt is declared to be a sovereign state

2. As soon as the Government of His Highness shall pass an Act of Indemnity with application to all inhabitants of Egypt, Martial Law, as proclaimed on 2 November 1914 shall be withdrawn. 3. The following matters are absolutely reserved to the discretion of His Majesty's Government until such time as it may be possible by free discussion and friendly accommodation on both sides to conclude agreements in regard thereto between His Majesty's Government of Egypt:

(a) The security of the communications of the British Empire in Egypt

(b)The defense of Egypt against all foreign aggression or interference, direct or indirect

(c) The protection of foreign interests in Egypt and the protection of minorities

(d) The Sudan. ${ }^{44}$

While the Egyptians governed themselves, the British maintained what could best be termed suzerainty over Egypt and the four points of reservation allowed a heavy British

${ }^{43}$ Ibid., 240.

${ }^{44}$ Declaration of the Abolition of the Protectorate and Independence of Egypt 2-28-1922 in Marlowe, 248. 
hand in Egypt. The first point referencing the security of imperial communications is clear reference to the canal and when coupled with the second point of protection from foreign aggression, cemented the ability of Britain to maintain troops and act in defense of the canal in Egypt. The British gave up the burden of governing Egypt, but they still held on to their right to defend the canal and wield considerable influence in Egypt. The third point also referred to foreign interests and extraterritoriality in Egypt, with the canal as one the largest interests. Since multiple countries needed the canal to remain open, the British still upheld the 1888 Convention. Essentially, the granting of Egyptian independence saw Britain cut all of her administrative ties to Egypt except those pertaining to her role as canal guardian.

The reserved points formed a constant bone of contention between the Wafdists and successive British Governments. In 1924 the Labour Government, led by Ramsay MacDonald, came to power and the new Prime Minister met with Saad Zaghul in the autumn of that year. Zaghul made five demands aimed at evicting Britain from Egypt, the most taxing being the demand for Britain to renounce all claims and rights to the Suez Canal. ${ }^{45}$ Commons debated Zaghul's demands. The first issue of concern raised by MacDonald was the canal, and he summed up British policy by stating,

I raised the question of the Suez Canal straight away because its security is of vital interest to us both in peace and war. It is no less true today than in 1922 that the security of the communications of the British Empire in Egypt renders a vital British interest and the absolute certainty that the Suez Canal remain open in peace as well as in war for the free passage of

\footnotetext{
${ }^{45}$ Schonfield, 76.
} 
British ships is the foundation on which the entire defense policy of the British Empire rests. ${ }^{46}$

If any doubt existed to the importance of the Suez Canal to British defense policy, MacDonald laid those fears to rest. MacDonald referred to the failure of the 1888 Convention and the internationalization of the canal to provide for free transit in World War I. He reminded Commons that Britain was forced to take steps to maintain the free passage of the canal and that no British Government would allow the closure of the canal. ${ }^{47}$ Macdonald reaffirmed the British policy of no British Government allowing the closure of the canal, which was also uttered during the 1882 crisis. A January 24, 1927 letter from Secretary of State for Foreign Affairs Austen Chamberlain to Egyptian High Commissioner Lord Lloyd conveyed similar sentiments by saying "the protection of the Suez Canal was considered of such vital importance to Great Britain that she was unwilling under any circumstances to entrust this to the Egyptian government alone.”48 In the same debate as MacDonald’s speech, F.C. Thomson, a member of Parliament in 1922, stated "it does not seem to me that there could be any interest more vital to the British Empire than the preservation of our communications through the Suez Canal.”49 These reserved points hindered Egypt until 1936, when the 1936 Anglo-Egyptian Treaty of Alliance resolved the issue. The canal was of dire importance to the British Empire at this point in time. The canal's role as a communications nodal point was still apparent

\footnotetext{
${ }^{46}$ British Policy in Egypt, October 7- November 22, 1924 in Hurewitz, 129.

${ }^{47}$ Ibid.

${ }^{48}$ Sir Austen Chamberlain to Lord Lloyd 1-24-27 in Hallberg, 364.

${ }^{49}$ Hallberg, 368.
} 
and the British were so adamant on keeping the canal open to shipping that they would not allow any other group to administer it. British granting of Egyptian independence was dependant upon the British exercising their role as canal guardians.

At the conclusion of the multitude of peace conferences and settlements following World War I, Britain had acquired several territories and mandates in the Middle East including Iraq, Transjordan, and Palestine. ${ }^{50}$ These new possessions served to deepen British attachment to the region and placed the canal as the centerpiece of the new empire. The canal occupied a role as the gateway to the exotic lands of the east and author E.M. Forster thought “somewhere about Suez there is always a social change, the arrangements of Asia weaken and those of Europe begin to be felt." ${ }^{51}$ During the interwar period, the debate over independence for India began to arise and the former romantic realm made famous by Kipling waned. However, the Middle East offered a vestige of the old imperial might where Britain could still make kings. Also a similarity existed in the new Middle East holdings that paralleled the old way of rule in India. As historian David Cannadine observed, "the Arab emirs and sheikhs seemed like the Indian princes and Nigerian emirs, only more so noble and superior leaders, the patrons and protectors of a

\footnotetext{
${ }^{50}$ For a detailed look at the settlements and the British Administration in the region see the following: David Fromkin, A Peace to End All Peace: The Fall of the Ottoman Empire and the Creation of the Modern Middle East (New York: Avon Books, 1989), Elizabeth Monroe, Britain’s Moment in the Middle East (Baltimore: Johns Hopkins University Press, 1981), Daniel Silverfarb, Britain’s Informal Empire in the Middle East (New York: Oxford University Press, 1986); Peter Sluglett, Britain in Iraq 1914-1932 (London: Ithaca Press, 1976); and Mary C. Wilson, King Abdullah, Britain, and the Making of Jordan (Cambridge: Cambridge University Press, 1987).

${ }^{51}$ E.M Forster, A Passage to India (New York: Modern Library, 1924), 72.
} 
traditional ordered world, which once existed but was now under serious threat.. ${ }^{, 52}$ While India was still the most important imperial holding, the social structure and British power in India were diminishing. Essentially, the Middle East offered a new place for the British to rule absolutely, while they still maintained India and attempted to alter their rule to maintain their control. The old romantic imagery of Britain ruling supreme over exotic lands in India was in danger of being eradicated, but the lands of the mandates offered a replacement. Cannadine continued, "the growing attachment to the Arab World, by turn patrician, romantic, and escapist, coincided with the gradual extension of British power into the Middle East. ${ }^{\text {} 53}$ British dominance over states formed under their auspices and the influence they wielded over the monarchs of these lands allowed for a sense of traditional empire. After all, the Middle East was the land of Lawrence and his adventures, which were growing ever popular with the publication of his books and the traveling lecture tour. The British created kings in these regions and did so under the condition these loyal monarchs accept their advice and preserve imperial communications. ${ }^{54}$ These new possessions allowed for the preservation of the canal, ensured the security of the canal with the buffer of Palestine, and completed an overland communications and air route to India through Egypt, Palestine, Transjordan, and Iraq. The security benefits for Britain were immense and the British ability to make rulers along the lines of those in the Indian Princely State rendered the Middle East a substitute

\footnotetext{
${ }^{52}$ David Cannadine, Ornamentalism ( Oxford: Oxford University Press, 2001), 72.

${ }^{53}$ Ibid., 73.

${ }^{54}$ Ibid.
} 
India. ${ }^{55}$ The canal formed the key to these lands and the tales of the adventures of Lawrence and later adventures of Glubb. The canal was the centerpiece of the new empire in the Middle East.

After the 1920s, the canal dropped in importance based on regional issues, the dominant spirit of peace stemming from Locarno, the Washington Naval Conference, and Kellogg-Briand, a pacifist British public, and the changing world order. The 1928 Kellogg-Briand Pact was signed by virtually all states, who agreed to refrain from military action as a way to settle international disputes. ${ }^{56}$ The Treaty of Locarno was the settling of Germany's western borders. ${ }^{57}$ Locarno also was an agreement among the major powers of Europe to settle conflict through peaceful means. The Washington Naval Conference took place from 1921 to 1922 and placed proportional limits on the naval strength of the world navies. ${ }^{58}$ The conference was hailed by United States Secretary for State Frank Kellogg as a great step towards peace. ${ }^{59}$ The result of these three treaties was the birth of the spirit of Locarno, essentially a sense of the end of the age of war. Though at the end of the First World War the canal had emerged as the swing door of the empire and the vital lifeline without which the empire could not stand, this shifted in the 1930s as the empire began to question its own power. The swing door distinction derived from both economic and political concerns. Economically, the canal allowed for the continued

\footnotetext{
${ }^{55}$ Ibid.

${ }^{56}$ Hans Gatzke, European Diplomacy between Two Wars, 1919-1939 (Chicago: Quadrangle Books, 1972), 10.

${ }^{57}$ Ibid., 83-89.

${ }^{58}$ Robert H. Ferrell, Peace in Their Time (New York: W.W. Norton, 1952), 43-44.

${ }^{59}$ Ibid.
} 
flow of trade between Britain and her empire. Politically, the canal allowed for a linkage of the empire and the ready dispatch of British or Indian troops to defend the empire. The British army decreased in size during this period of time. The fallout of World War I and the emergence of the so called "lost generation” left many Britons unwilling to support any martial activity. ${ }^{60}$ The army became stigmatized and beset by "a pacifist electorate, a parsimonious treasury, and uncertainty over its role.”61 The War Ministry was unpopular with the British public and the officer ranks rife with resignations. ${ }^{62}$ The focus on air defenses left the British army in disrepair and presumably unable to maintain the defense of the empire. ${ }^{63}$ The British Government placed their faith in the Air Ministry defending the empire and ignored the army, which had suffered so much during the last conflict. The government also adopted the Cardwell system which advocated equal forces to be allotted for home and imperial defense leaving the majority of the army stationed in Britain or in India. ${ }^{64}$ For example the British stationed forty-five battalions in India and only six in Egypt. The gateway to India and the canal, which had been the scene of two British military activities, became expendable. ${ }^{65}$ The Kellogg-Briand Pact and the spirit of Locarno mesmerized the British Government and British ministers believed that no future war would occur. It ordered the military on the Ten Year Rule, calling for the

\footnotetext{
${ }^{60}$ The best depiction of the horrors of World War I for the British is found in Paul Fussell, The Great War and Modern Memory (Oxford: Oxford University Press, 1975).

${ }^{61}$ Brian Bond, British Military Policy between the two World Wars (Oxford: Clarendon Press, 1980), 37.

${ }^{62}$ Ibid., 37-41.

${ }^{63}$ Ibid.

${ }^{64}$ Ibid.

${ }^{65}$ Ibid.
} 
armed forces of the empire not to prepare for war for ten years. ${ }^{66}$ While the Ten Year Rule was also a cost cutting measure, the willingness of the Government in disallowing military preparation meant that in any future conflict, the British lagged behind countries that had maintained military preparations. In terms of the Middle East, the British Government left only minimal detachments of the army, presumably only enough to subvert any local rising. The reason for the troop reduction in the Middle East was described by historian Elizabeth Monroe, "Britain remained paramount in the Middle East, unchallenged by any power of equal magnitude and able to maintain order thanks to the security and aura of empire and its ability to summon reinforcements from India and Malta in time of need. ${ }^{, 67}$ Monroe believed that there was no need for more troops in the Middle East at this time. At the end of this redeployment, one cavalry brigade, one tank brigade, and one infantry brigade defended the canal and Egypt, a far cry from the seventy thousand men of the EEF who defended the canal during World War I.

Developments in Iraq and Egypt led to some indecision with regards to the canal. The weakness stemmed from the perceived weakness of Britain in the region due to treaty concessions during the 1930s. Iraq had become a vital imperial center for fly over purposes and it was a chain in the Indian shield that began at Suez. In 1930, the British signed a treaty of alliance granting Iraqi independence and severely restricting their

\footnotetext{
${ }^{66}$ Ibid., 82-5.

${ }^{67}$ Elizabeth Monroe cited in Bond, 85.
} 
military presence in Iraq. ${ }^{68}$ The treaty allowed the Royal Air Force to retain four bases and the British assured responsibility for the defense of Iraq. The British created a pliant monarchy for the sake of preserving imperial communications. ${ }^{69}$ The treaty with Iraq was followed shortly by renewed negotiations with Egypt. The 1936 Anglo-Egyptian Treaty of Alliance settled the point of reservation included in the 1922 Declaration. The treaty replaced the British military occupation with an alliance and called for the termination of the British military presence in Egypt. ${ }^{70}$ Article VIII preserved the canal stating:

In view of the fact that the Suez Canal, while being an integral part of Egypt, is a universal means of communication between the different parts of the British Empire, His Majesty the King of Egypt, until such time as the High Contracting Parties agree that the Egyptian Army is in a position to ensure by its own resources the liberty and entire security of the navigation of the Canal, authorizes His Majesty the King and Emperor to stations forces in Egyptian territory in the vicinity of the Canal, in a zone specified in the annex to this Article, with a view to ensuring in cooperation with the Egyptian forces the defense of the Canal. ${ }^{71}$

Article VIII also created the Canal Zone, which was to be controlled and administered by Britain and would become one of the largest military bases in the world. The Annex allowed for a twenty-year period of British occupation before the Egyptians took full control of the defense of the canal and read:

It is understood that at the end of the period of twenty years specified in Article 16 the question whether the presence of British forces is no longer necessary owing to the fact that the Egyptian army is in a position to

\footnotetext{
${ }^{68}$ Daniel Silverfarb's Britain's Informal Empire in the Middle East is written solely on the 1930 treaty and is the best available account on the topic.

${ }^{69}$ Sluglett, 259.

${ }^{70}$ Article I of the Anglo-Egyptian Treaty of 1936 in Marlowe, 444.

${ }^{71}$ Article VIII of the Anglo-Egyptian Treaty of 1936 in Marlowe, 445.
} 
ensure by its own resources the liberty and entire security of navigation of the Canal may, if the High Contracting Parties do not agree thereon, be submitted to the council of the League of Nations for decision in accordance with the provisions of the Covenant in force at the time of the signature of the present treaty or to such other persons for decision in accordance with such other procedures as the High Contracting Parties may agree. ${ }^{72}$

While the British ended a costly military occupation, they managed to maintain their presence in the canal area and to defend it for twenty more years. The interesting development is Britain’s willingness to part with the occupation of Egypt and supposed consideration of entrusting Egypt with the defense of the canal in the future. The rationale stretched a long distance from the attitude of the MacDonald Government, but the treaty agreements regarding the canal were most likely an attempt to stall a handover for the foreseeable future. The reason was that Britain was still weakened from World War I, suffering monetary issues, disinclined to martial activity, and most importantly, a larger issue in the world loomed: fascism.

In the early 1930s, the threats to the British Empire came from two sources: Japan and Italy. During World War I, Japan was a British ally and acted to protect British interests in the Far East; but, times had changed. By the 1930s, the Anglo-Japanese alliance was terminated and Japan was now ruled by a military government. The British desired to pursue closer ties with the Americans and allowed the military alliance with Japan to lapse in the 1920s. ${ }^{73}$ A cooperative agreement between the United States,

\footnotetext{
${ }^{72}$ Annex to Article VIII of The Anglo-Egyptian Treaty of 1936 in Marlowe, 445.

${ }^{73}$ Ian Nish, Japanese Foreign Policy in the Interwar Period (Westport, CT.: Praeger Press, 2002), 28.
} 
Britain, Japan, and France replaced the naval treaty between Japan and Britain. ${ }^{74}$ This suspicion of Japanese hostility led to considerations of the eastern holdings. The Washington Naval Conference limited the size of the Japanese navy, but left the Japanese the dominant naval power in the Pacific. ${ }^{75}$ Japan also felt slighted by the proportions se at the conference and the British termination of the Anglo-Japanese alliance. ${ }^{76}$ British policy makers decided to use Singapore as the forward base in the Far East and in time of trouble to dispatch half of the main fleet to the Far East. ${ }^{77}$ Italy was not considered a threat and it was not believed that the British could defend the Home Islands, Egypt, and the Far East simultaneously. The Italian incursions into Abyssinia threatened the British position in the region and placed the canal in danger. While Britain allowed Italian troop movements through the canal, there was the possibility of these transports disembarking their troops and claiming the canal. The conquest of Abyssinia further entrenched Italy on either side of the canal, when coupled with her control of Libya. The British had the opportunity to prevent the Italian invasion by closing the canal to their warships, but the British chose not to and wished to avoid fighting the Italian army. The British fear of the Italians demonstrated the diminution of British martial strength, effect of the spirit of Locarno after World War I, and the folly of the Ten Year Rule. The threat of the Italians led the British to undertake the terms of the 1936 Anglo-Egyptian Treaty, which

\footnotetext{
${ }^{74}$ Ibid., 26-31.

${ }^{75}$ Ferrell, 43-44.

${ }^{76}$ Exact proportions were U.S. and UK 5, Japan 3, Italy and France 1.66, taken from Lawrence James, The Rise and Fall of the British Empire (New York: St. Martin’s Press, 1994), 459.

${ }^{77}$ Ibid.
} 
generated a benefit in the forcing of the Egyptians to acknowledge the vital role of the canal for imperial communications and the granting of RAF flyover rights. The British assumed that no power would challenge their hold over the Middle East and they concentrated on the Japanese threat to their eastern holdings. The dispute between the RAF and Admiralty had led to the defenses on Malta becoming neglected and the British proved unprepared to deal with a Mediterranean threat. ${ }^{78}$ The RAF and Admiralty believed their respective branches were best suited for defense in coming conflicts. The Chamberlain Government even contemplated withdrawal from the region to avoid conflict. $^{79}$ The 1937 Imperial Conference called for the Far East to be the priority for imperial defense and advocated a doctrine of self-sufficiency for the defense of Egypt. ${ }^{80}$ Self-sufficiency required the three brigades in Egypt to hold out as long as possible against any invasion and to await reinforcements. ${ }^{81}$ While a rapprochement was pursued with Italy, the canal was relegated by policy makers to less important than the Singapore base and only allotted three divisions for defense. The rapprochement allowed a sense of Mediterranean security and gave British planners time to focus on the defense of the Far East.

Some British statesmen called for the Government to sacrifice the Mediterranean due to the disrepair of the British Navy and the need to defend India. Foreign Minister

\footnotetext{
${ }^{78}$ Lawrence Pratt, East of Malta, West of Suez: Britain’s Mediterranean Crisis 1936-1939 (Cambridge: Cambridge University Press, 1975 ), 11.

${ }^{79}$ Ibid., 34.

${ }^{80}$ Ibid.

${ }^{81}$ Martin Kolinsky, Britain’s War in the Middle East: Strategy and Diplomacy 1936-1942 (London: MacMillan Press LTD., 1999), 21.
} 
Anthony Eden believed that the Mediterranean could be lost and later regained if necessary. ${ }^{82}$ In years past when the threats came from Europe the canal had been the security of India; with the increased perception of the Japanese threat, Singapore proved the key. The Committee of Imperial Defense so preoccupied itself with a three front war that they postulated a plan to have the French Navy guard the canal. ${ }^{83}$ Circumstances in 1938 necessitated another shift in canal importance as it became more and more likely that Italy would be a likely opponent of Britain in any future war. Italian involvement in the Spanish Civil War, Italian rearmament, and the increase of the garrison in Abyssinia worried London and foreshadowed Italian aggression. ${ }^{84}$ British policy makers believed that the control of the canal allowed Britain to sever the Italian communications to her East African colonies and to secure Alexandria, which would be the main British base in any conflict. ${ }^{85}$ Also in any future conflict, the powerful Indian army would be needed to aid the war effort. In 1938 reinforcements began to be dispatched to Egypt and were agreed to by Egyptian Government, which had grown fearful of the increased troop Italian deployments to Libya. The Admiralty dispatched the Mediterranean fleet to Alexandria. ${ }^{86}$ The British had flip-flopped for a few years over the importance of the canal versus that of Singapore; but, as the Second World War approached, the canal regained its place as a necessary holding for the British Empire. The reasons for the

\footnotetext{
${ }^{82}$ Pratt, 54.

${ }^{83}$ Ibid., 69.

${ }^{84}$ Ibid.

${ }^{85}$ Ibid., 77.

${ }^{86}$ Ibid., 121.
} 
vacillation stemmed from the multiple threats facing the empire. When Japan appeared the most likely enemy, Singapore received priority at the expense of canal defense. Also, the vacillation stemmed from a limited amount of money and supplies, resulting in whichever base was threatened, be it Suez or Singapore, received troops and support. But when the canal was threatened, the pendulum swung back to defense of the canal as primary.

In 1939, Winston Churchill proclaimed the Mediterranean England's first battlefield and the Egyptian Government asked for even more British troops to be dispatched. ${ }^{87}$ The British Government decided that despite some initial trepidation over the ability to hold Egypt during a war, the canal had to be held and the Mediterranean won. The detriment was that for this strategy to work the United States had to use their fleet to check the Japanese fleet in the Pacific and the Franklin Roosevelt Administration was more willing to preserve their isolationist stance than to actually aid against Japan. ${ }^{88}$ While this strategy failed, the British had committed themselves to preserving Egypt. However, in the event of conflict with Italy, Egypt was the jumping off point from which Britain could attack Libya and Abyssinia and strangle Italian communications and colonies. The 1939 St. James Conference stressed the importance of Egypt as a hub of communications and it was grouped as one of the three most important holdings in the

\footnotetext{
${ }^{87}$ Ibid., $175-180$.

${ }^{88}$ For a description of the failure of the Anglo-American cooperation in the Pacific see Nicholas Clifford, "Britain, America, and the Far East 1937-1941: A Failure in Cooperation," in Journal of British Studies Vol. 3, No.1 (1963):137-154.
} 
region. ${ }^{89}$ In 1939, Britain strengthened its air defenses around the canal in 1939 and the British prepared for another defense of the canal against a European enemy. While the initial strategic planning had painted the canal as expendable in favor of Singapore, the realization of a European conflict left Britain with no choice but to defend the canal. Such a defense sought to prevent any incursion against Egypt or their position in the Middle East. The problem was that the Ten Year Rule and Cardwell system had weakened the British military and left it unprepared for war.

The Second World War once again saw the return of hostilities to Egypt and rekindled the omnipresent fear of an attack on the canal. The Churchill Government decided to make a stand in the Mediterranean and forsake their earlier plans to dispatch the fleet to Singapore. ${ }^{90}$ Early British experience in the war showed the lingering effects of the Ten Year rule and saw the British Expeditionary Force swept from the Continent saved only by the miracle of Dunkirk. ${ }^{91}$ While the Germans overran British resistance in Europe, the Italians declared war on June 10, 1940. Their declaration implied attacks against Suez and Gibraltar. ${ }^{92}$ The British responded by refusing canal entry to the ships of both Germany and Italy. ${ }^{93}$ The British forces in the canal placed guards at the two entry points to the canal and stopped all ships from entering the canal without security

\footnotetext{
${ }^{89}$ Kolinsky, 97. The two other important holdings were the Persian oilfields and the Northwest frontier. ${ }^{90}$ For information on the token naval opposition to the Japanese campaigns in the Pacific see Christopher Bell, "The Singapore Strategy and the Deterrence of Japan: Winston Churchill, the Admiralty, and the Dispatch of Force Z,” English Historical Review Vol. 116, No. 467 (2001):604-634.

${ }^{91}$ Viscount Montgomery, The Memoirs of Field Marshall, the Viscount Montgomery of Alamein, KG (New York: the World Publishing Company, 1958), 37-43.

${ }^{92}$ Winston Churchill, The Second World War Volume 2 Their Finest Hour ( Boston: Houghton Mifflin Co., 1949), 122-124.

${ }^{93}$ Morewood, 91.
} 
clearances. British commanders in Egypt clamored for anti-aircraft batteries. ${ }^{94}$ The Italian air force mounted some air attacks on the canal, but the inaccurate Italian bombing resulted in little damage. Additionally; the troop buildups in the Italian African colonies suggested a land attack. The British stopped the Italian naval threat on November 11-12, 1940 when the Royal Navy sank three Italian battleships in their moorings and confirmed the British dominance of the naval portion of the Mediterranean theater. ${ }^{95}$ While the canal may have been temporarily secured, it was feared that the main attack on the canal would come from the land as in World War I.

The land portion of the North African Campaign would be decided along the borders between Libya and Egypt. The Italians had stationed over 215,000 troops in Libya, and they confronted fifty thousand British troops in Egypt. ${ }^{96}$ Campaigning in North Africa took the form of a shoving match with the Axis attempting to push their way into Egypt in an effort to take the canal with the British impeding their efforts and attempting to push the Axis out of North Africa. The Italians mentioned reclaiming the Roman Empire and the War Cabinet became determined to defend Egypt and sent the best available armor to Egypt. ${ }^{97}$ Notably the Churchill Government made this decision during the height of the Battle of Britain and heightened the importance of Egypt and the canal. The Italian advance on Egypt began in the summer of 1940 and the British Long

\footnotetext{
${ }^{94}$ Ibid.

${ }^{95}$ John Keegan, World War II (New York: Viking Press, 1996), 147.

${ }^{96}$ Churchill, Their Finest Hour, 418.

${ }^{97}$ Ibid., 418 and 436.
} 
Range Desert patrol harassed their advance. ${ }^{98}$ Churchill lobbied for more troops to be dispatched to Egypt and troops from all over the empire began to arrive. Once again the canal was the conduit for imperial troops to rally to the crown and defend the artery of the empire. ${ }^{99}$ In 1940, Churchill wrote to the Prime Ministers of New Zealand and Australia informing them of the decision to keep the fleet at Alexandria and called on India and Australasia to dispatch any available troops to Egypt. At the same time as the British fleet defeated the Italians, the British forces in Egypt pushed the Italian army back to Tobruk and were on the verge of claiming victory in the region. ${ }^{100}$ The British had staved off defeat in Europe and secured the canal through their victories in Egypt. Churchill commented. "by the end of that year this small and ancient island, with its devoted Commonwealth, Dominions, and attachments under every sky had proved itself capable of bearing the whole impact and weight of world destiny."101 Defeating the Italians in North Africa was a temporary reason for self-congratulation, but then the Germans got involved in the campaign.

On September 6, 1940, Admiral Raeder of the German Navy suggested to Hitler of the need to take the canal before United States aid arrived and Hitler resolved to drive the British from the canal. ${ }^{102}$ Yet again, a British enemy had decided that the best way to hamper the empire was to take the canal. On January 18-19, 1941, the Luftwaffe attacked

\footnotetext{
${ }^{98}$ Ibid., 418.

99 Ibid.

${ }^{100}$ Ibid., 621-7.

${ }^{101}$ Ibid., 628.

102 Kolinsky, 9.
} 
installations along the canal and dropped mines into the canal. ${ }^{103}$ The presence of mines resulted in repeated closures of the canal and the British dispatched all available mine clearing equipment to the canal. ${ }^{104}$ Additionally, the shipping problems caused by German air attacks delayed the arrival of anti-aircraft equipment and that equipment did not arrive until spring, rendering the canal vulnerable to German attacks. Germany had initially intended to send troops to aid the Italian war effort, but reassigned them to Greece in October of $1940 .{ }^{105}$ The AfrikaKorps arrived in February of 1941 and the general who led the troops was the most feared German commander of the war: Erwin Rommel. ${ }^{106}$ Rommel's forces began to regain ground lost by the Italians and forced the British forces to retreat over three hundred miles. ${ }^{107}$ Rommel defeated the British forces and captured the vital fuel depot/port of Tobruk, thereby infuriating Churchill. ${ }^{108}$ The fall of Torbuk was the second largest British capitulation of the war and 35,000 British prisoners were taken. ${ }^{109}$ Upon hearing of the fall of Tobruk, Churchill remarked, "defeat is one thing, disgrace is another." ${ }^{, 110}$ The Germans were getting dangerously close to the canal. Something had to be done by the British.

\footnotetext{
${ }^{103}$ Morewood, 92.

${ }^{104} \mathrm{Ibid}$.

${ }^{105}$ Keegan, 144.

${ }^{106}$ John Bierman and Colin Smith, The Battle of Alamein: Turning Point of World War II (New York: Viking Press, 2001), 68.

${ }^{107}$ Winston Churchill, World War II Volume 4 the Hinge of Fate (Boston: Houghton Mifflin Co., 1950), 20-35.

${ }^{108}$ Bierman and Smith, 184.

${ }^{109}$ Ibid.

${ }^{110}$ Ibid.
} 
Churchill decided to make Bernard Montgomery commander of the British Eighth Army and he hoped that Montgomery could find a way to stunt the German advance. Montgomery began to make a myth for himself starting with his appointment. As Montgomery was walking to the plane to take him to Egypt, he spoke of a great general who won many victories only to be defeated in the desert. At this statement, his aide reassured of him of his chances versus Rommel, and Montgomery responded that he had been talking about Rommel. ${ }^{111}$ Montgomery took control and began preparations for a showdown with Rommel. He refused Churchill's call for a September offensive because he did not want to fight until he was ready. In August of 1942, Britain prepared Cairo for street to street fighting and the British Army issued rifles to civil servants, few hoped of stopping Rommel. ${ }^{112}$ But Montgomery had hope and benefited from the Royal Air Force’s sinking of Axis shipping to North Africa. ${ }^{113}$ The lack of supplies bought vital time for Montgomery to supply and train.

In late October and early November, the Battle of Alamein commenced with the Germans attacking the Eighth Army and the Eighth stopping their advance once and for all. The battle was a triumph for the Eighth Army, composed of men from Britain, India, Australia, New Zealand, and South Africa. The British beat back the supposedly invincible Afrikakorps and the Eighth began to push the Axis forces westward towards Tunisia. By January 1943, the British entered Tripoli and the North African theater was

\footnotetext{
${ }^{111}$ Montgomery, 71-2.

${ }^{112}$ Churchill, The Hinge of Fate, 522.

${ }^{113} 30 \%$ of Axis shipping bound for North Africa was sunk in September and 40\%in October cited in Ibid., 587-9.
} 
won. The victory at Alamein proved a triumph of tactics and the use of the superior manpower of the Eighth Army. ${ }^{114}$ At Tripoli, Churchill addressed the men of the British Eighth Army saying, "ever since your victory at Alamein, you have nightly pitched your moving tents a day's march nearer home. In days to come when people ask what you did in the Second World War, it will be enough to say: I marched with the Eighth Army.”115 By the end of 1943, the British evicted the Axis from North Africa and the canal was safe because as Montgomery stated, "the Eighth Army never withdraws."116 The battle of Alamein was the beginning of the end for the German war effort and began a series of Allied victories. As Churchill noted, "before Alamein we never had a victory, after Alamein we never had a defeat.",117

The end of World War II also brought about a momentous shift in the world political spectrum. Britain perceived itself to have borne the brunt of a German attack and was, along with the rest of Europe, in need of rebuilding. Fascism was defeated and Germany divided, but the end of the war also left the world torn between the two superpowers: the United States and the Union of Soviet Socialist Republics. The Cold War became an event filled with diplomatic intrigue and proxy wars where each side claimed regions of the world for their influence. And the Cold War confronted Britain with a decision to make. They could make a claim to being a world power; after all, the empire was still intact and the British were one of the victorious allies in the war.

\footnotetext{
${ }^{114}$ For a comprehensive telling of the battle of Alamein see Bierman and Smith.

${ }^{115}$ Montgomery, 136-140 and Bierman and Smith, 256.

${ }^{116}$ Montgomery, 145.

${ }^{117}$ Churchill, The Hinge of Fate, 608.
} 
However, Britain was not in any economic or political state to compete with the two other powers. Additionally, the forces of nationalism and calls for decolonization became overwhelming as many parts of the empire called for independence, most notably India in 1947. The only region under firm British control was the Middle East and the British controlled the region to safeguard of the route to India and to defend the canal. The canal remained under British control as the Cold War began and the Middle East took on renewed importance in the geopolitical contest. Britain attempted to define its role in the Cold War and still laid claim to dominance in the Middle East. The British viewed their role as holding the Middle East against the forces of communism. The most important holding in the Middle East was the canal. Ironically the canal sparked the events that led to the downfall of the British Empire. 


\section{Chapter IV}

\section{Parting Ways with the Canal: Postwar British Policy and the Struggle with Nasser}

The British emerged among the victorious in World War II and as the dominant power in the Middle East. Though weakened by war, the British Empire had survived its most dire test, but the tide of world politics was changing. During the period from 1945 to 1956, Britain's role in world affairs changed and Britain also endured indecision over the importance of the canal in its foreign policy. One of the main reasons for control of the canal vanished when India gained independence on 15 August $1947 .^{1}$ The loss of India robbed the canal of its first importance and the Labour Government of Attlee pondered withdrawing from the canal. The British obligated themselves to withdraw from Egypt by 1956 under the terms of the 1936 Treaty of Alliance, but the canal took on renewed importance during the Cold War. During this period British policy towards the canal can be divided into two main phases: realization and regression. Realization encompasses the British attempts to deal with the Middle East in light of the changing world political scene. Essentially, the realization phase represents British attempts to move from a heavy handed approach to the region to one of more equality through alliances. The phase of realization occurred under the Attlee Government. During this period, the British Government evacuated the Middle East and created alliances with the

\footnotetext{
${ }^{1}$ Lawrence James, The Rise and Fall of the British Empire (New York: St. Martin’s Press, 1994), 552.
} 
countries of the region. In the late 1940s, the British showed a willingness to withdraw from Egypt and relocate to an alternative base in Palestine or Libya. The termination of the Palestine Mandate ended British hopes of finding an alternative base and demonstrated the inability of the Arab states to defend themselves against military attack. Prior to the 1948 Arab-Israeli War, the British had hoped to develop the Arab States into an economic and political entity that, with Anglo-American assistance, could serve as a bulkhead against communist intrusion. ${ }^{2}$ The phase of regression began with the return of the Conservative Party to power in Great Britain in 1951. The regressive phase refers to British policy returning to a heavy handed approach in the Middle East. Though responsible for the 1954 Anglo-Egyptian Treaty, the Governments of Churchill and Eden acted with a heavy hand in the Middle East and influenced the region much as they had prior to World War II. The Conservative policy met with minimal success and was defeated by Egypt in efforts to form the Baghdad Pact, the dismissal of Glubb, and the Suez Crisis. By the end of this period, the British withdrew from the canal but later returned to the region to guarantee its international character. The British refusal to act in accordance with changing political tides and their failure to realize their power in comparison with the Soviet Union and United States resulted in the failure of Britain to keep the canal open. The canal had occupied a central role in the policy of many British Governments and, ironically, began the end of the empire.

\footnotetext{
2 John Marlowe, A History of Modern Egypt and Anglo-Egyptian Relations 1800-1956 (Hamden, CT.: Archon Books, 1965), 369-370.
} 
The end of the Second World War divided the world political scene between the United States and the Union of Soviet Socialist Republics with Britain on the sidelines. Nevertheless, the British still viewed themselves as a world power and wanted to maintain their influence. Cold War pressure encouraged an exaggerated notion of imperial interest with the Middle East occupying extreme importance. ${ }^{3}$ The independence of India took away the region's role as the gateway to the Indian Empire, but afforded the region a certain level of importance. Immediately after the war, the Middle East was the one region in the world where American or Soviet influence was not universal and Britain acted as the custodian of Western interests. ${ }^{4}$ As historian John Darwin noted, "Egypt was the heart of the British strategy in the Middle East and the war had proven the incalculable asset the land was in war with airfields, a large labor force, agriculture, position, and above all the canal. ${ }^{5}$ Bernard Montgomery, the hero of World War II, stressed the importance of the Suez base and having the installations in Egypt available "for use by our forces in war and ... the right to station forces in strategic area and to move them in and through the Middle East.”6 While Britain viewed itself as a vital player in the Cold War, that view came to resemble more of an illusion during the post war period.

\footnotetext{
${ }^{3}$ John Darwin, Britain and Decolonization: the Retreat from Empire in the Postwar World (N.Y., St. Martin’s Press, 1988), 145.

${ }^{4}$ Ibid., 155-160.

5 Ibid., 113.

${ }^{6}$ Viscount Montgomery, The Memoirs of Field Marshall, the Viscount Montgomery of Alamein, KG (New York: the World Publishing Company, 1958), 376.
} 
Harold Macmillan, who later became prime minister after the Suez crisis of 1956, evaluated the situation in post-war Britain saying,

Britain's weakness had been temporarily concealed by the glamour of our victory. Authority had been enhanced by the single handed resistance to Hitler in 1940-41 and by the disproportionate number of forces which Great Britain had put into the field and their splendid feats of arms. ${ }^{7}$

While Montgomery advocated the indispensability of the Middle East and the use of the region to meet any aggression from the East, Macmillan wanted to maintain friendly terms with the Soviet Union. ${ }^{8}$ Macmillan realized the diminution of British power. He also wanted to secure Commonwealth support for British foreign policy and "reduce our forces as was consistent with the maintenance of our influence."9 The differing views held by Montgomery and Macmillan foreshadowed the pendulum of British policy towards the Middle East from 1945 to 1956. Many in Britain advocated the maintenance of world power status and standing guard in the region against the forces of communism while others were aware of the declining power of Britain. The one aspect both sides of the dispute agreed upon was the importance of the Suez Canal, be it for defensive purposes or for access to Middle Eastern oil. As political scientists Leon Epstein noted prior to World War II, "the Suez Canal emerged as the imperial lifeline, the basis of Britain's world trade, and the route to India.” ${ }^{10}$ While correct, the canal did not as much emerge but regained the status it held prior to the wars. By the beginning of 1946, the

\footnotetext{
${ }^{7}$ Harold Macmillan, Tides of Fortune 1945-55 (N.Y.: Harper \& Row, 1969), 102.

${ }^{8}$ Montgomery, 390 and Macmillan 103.

${ }^{9}$ Macmillan, 103.

${ }^{10}$ Leon Epstein, British Politics During the Suez Crisis (Urbana, IL.: University of Illinois Press, 1964), 23.
} 
Middle East proved important to Britain and the one area where her power remained paramount; the incoming Attlee government, though, took a different view.

The Labour Government pursued a different foreign policy than Churchill’s Wartime Government and moved away from the previous heavy handed policy in the Middle East, but still maintained influence. The main proponent of this policy was Ernest Bevin, the Labour Foreign Minister. Bevin believed the Middle East was second in importance to Europe and that traditional intervention undermined the role of Britain in the region. ${ }^{11}$ The regeneration and maintenance of British influence was the only path to preserve Britain's world status and to avoid relegation to the status of the Netherlands. ${ }^{12}$ Despite believing in the benefit of the empire, Bevin believed in the need to replace the empire in the Middle East with partnership. The Suez base remained important and Attlee viewed it as necessary for oil, while Churchill believed the base to be the geographical key to the Middle East and one of the supreme geopolitical positions in the entire world. ${ }^{13}$ With the loss of India, the geographical relevance of Egypt lessened and Bevin looked for other areas to relocate the British base. The most apparent choice was Palestine. The problem was the British still viewed the Middle East as the focal point of communications with the empire and Commonwealth, a source of oil, a shield to Africa, and an irreplaceable offensive base, all which hinged on the maintenance of

\footnotetext{
${ }^{11}$ William Roger Louis, The British Empire in the Middle East 1945-51: Arab Nationalism, the U.S. and Postwar Imperialism (Oxford: Clarendon Press, 1984), 4.

${ }^{12}$ Ibid.

${ }^{13}$ Ibid., 8 .
} 
Suez. ${ }^{14}$ The British military presence at Suez allowed Britain to dominate the region and maintain their influence. The control of the Suez base safeguarded the passage of oil and preserved imperial communications. Also, the base served as a shield to Africa since the British presence provided an impediment to any Soviet threat to the region.

The Suez Base suffered a severe lessening in importance during the early Labour Government. While the military viewed the base as necessary to deter Soviet incursions, Bevin was willing to relocate the base to Cyrenaica. Despite Bevin’s views, the military viewed the Suez Canal as "vital to all British calculations, one of the principal justifications in imperial defense, the protection of the Indian Empire might no longer exist, but it remained the principal route to the East and a symbol of imperial power.”15 The Egyptian populace wanted the British to leave and the Egyptians longed for the unity of the Nile Valley under the Egyptian crown. Unity of the Nile Valley called for the union of Sudan and Egypt under the Egyptian monarchy, but had nothing to do with the canal. The British actions of strong arming King Farouk into accepting a Nationalist Government during the war humiliated Egypt and inspired Egyptian Nationalists. The Labour party advocated the withdrawal from Egypt on July 5, 1946 and entered into discussions to hand over the canal, a change in policies unfathomable only a few years earlier. $^{16}$

\footnotetext{
${ }^{14}$ Ibid., 17.

${ }^{15}$ Ibid., 119.

${ }^{16}$ Ibid., 231.
} 
Egyptian Prime Minister Ahmed Sidqi led an Egyptian delegation to London in 1946 to discuss revisions to the 1936 Treaty of Alliance and announced that he was in favor of a new alliance with Britain based on the complete evacuation of British forces from Egypt. ${ }^{17}$ Sidqi also agreed to leave the question of Sudan out of the treaty and reached an agreement with Bevin in London. The treaty entailed the evacuation of British troops from Egypt by 1949. ${ }^{18}$ Bevin's offer assailed the emotional and psychological basis of the imperialists in Britain. ${ }^{19}$ The British base at Suez stood as one of the largest military bases in the world and a testimony to British industriousness and resourcefulness. Additionally, the perceived sense of losing the canal was momentous since many British soldiers had perished to preserve the canal, only to see it handed back to the Egyptians in a matter of years. The agreement implied the lessening of Britain’s status in the Middle East due to the paramount status of the canal in the British position in the region. The agreement fell apart due to miscommunications between the two governments; in addition political rivalries resulted in the resignation of the Sidqi Government. The essential point was the willingness of the Labour Government to part with the canal. Another policy shift had occurred in relation to the Suez Canal. Only years removed from British soldiers perishing defending the canal against the forces of fascism, the British believed the canal was expendable.

\footnotetext{
${ }^{17}$ Marlowe, 341.

18 Ibid.

${ }^{19}$ Louis, 691.
} 
The rationale for the attempted withdrawal from Egypt was in accordance with the Labour strategy of propping up the Arab states as a bulwark against communism. The end of the Palestine Mandate and the 1948 Arab-Israeli War scuttled this strategy and the prospect of withdrawal from Egypt. The British decision to relinquish her mandatory power in Palestine and the subsequent creation of Israel exposed the weakness of the Arab states, countered British plans for an alternative base in Palestine, and lessened British prestige in the region. ${ }^{20}$ The relinquishment of the mandate fostered a sense of betrayal in the Arab world directed towards the British. Additionally, the Israeli defeat of the armies of Iraq, Syria, Lebanon, Egypt, and Jordan proved the inability of the Arab armies to act in coordination or to achieve success. The hope of utilizing the Arab states to forestall a communist attack fell apart and the British realized that their continued presence in the region was required. The character of British foreign policy took a drastic change with the return of the Conservatives to office in 1951.

The Conservative Government of Churchill returned in 1951 with Anthony Eden as Foreign Secretary. While Parliament was in recess, the Egyptian Government abrogated the 1899 Anglo-Egyptian Condominium and the 1936 Treaty of Alliance,

\footnotetext{
${ }^{20}$ for a description of the process, reasoning, and ramifications from the end of the Mandate see the following: Schonfield, The Suez Canal in Peace and War 1869-1969 , Marlowe, A History of Modern Egypt and Anglo-Egyptian Relations 1800-1956, Louis, The British Empire in the Middle East 1945-51: Arab Nationalism, the U.S. and Postwar Imperialism , Benny Morris, Righteous Victims: A Brief History of the Zionist-Arab Conflict 1881-2001 (New York: Vintage Books, 1999), Yezid Sayigh Armed Struggle and the Search for State (Oxford: Oxford University Press, 1999), two works by Michael Cohen Palestine and the Great Powers 1945-48 (Princeton, N.J.: Princeton University Press, 1982) and Palestine, Retreat from Mandate: the Making of British Policy 1936-1945 (New York: Holmes \& Meier,1978).
} 
thereby proclaiming unity of the Nile Valley. ${ }^{21}$ Though the abrogation accomplished little, it was a symbolic action demonstrating the Egyptian Government’s desire to confront Britain. Also in 1951, Egyptian labor was withdrawn from the Canal Zone and terrorist activity in the area increased. ${ }^{22}$ Rioting and attacks against British soldiers began in 1945 after there was no British move to evacuate Cairo. ${ }^{23}$ The Egyptians wanted to force the issue of British withdrawal and force Britain to the negotiating table. In January 1952, a British attack on an Egyptian police barracks touched off anti-foreign riots and resulted in attacks on British buildings and the massacre of several Englishmen. ${ }^{24}$ Later in 1952, the Egyptian monarchy was abolished and a military junta installed. On 23 July 1952, Mohamed Neguib and a few battalions of troops marched on Cairo, obtained the abdication of Farouk, and arranged for a new government. ${ }^{25}$ The effects of these events caused Eden to decide on a new settlement with the Egyptians. Eventually, Neguib became the Prime Minister and leader of Egypt, representing the Free Officers’ Movement. While Neguib held power, Lieutenant Colonel Gamel Abdul Nasser was the acknowledged leader of the movement and would become the leader of Egypt within nine months. ${ }^{26}$ The Egyptian Revolution had eliminated any claim to Sudan and allowed for

\footnotetext{
${ }^{21}$ Selwyn Lloyd, Suez 1956: A Personal Account (N.Y.: Mayflower Books, 1978), 1-12.

${ }^{22}$ Anthony Eden, Full Circle: the Memoirs of Anthony Eden (London: Cassell \& Co., 1966), 226 and John Glubb, Britain and the Arabs: A Study of Fifty Years 1908-1958 (London: Hodder \& Staughton, 1959), 322.

${ }^{23}$ Marlowe, 335.

${ }^{24}$ Eden, 226.

${ }^{25}$ Marlowe, 387.

${ }^{26}$ Ibid., 405.
} 
the new negotiations to be solely concerned with the canal. ${ }^{27}$ Essentially, Britain could withdraw from the canal and still have bases in the region to defend it.

Foreign Minister Anthony Eden decided to pursue a new settlement focused on phased withdrawal, maintenance of the base for British use in times of trouble, air defense cooperation, Egyptian participation in a Middle East defense organization, and Anglo-American assistance. ${ }^{28}$ Though a Conservative, Eden was conscious that the empire was in the words of his secretary Evelyn Shuckburgh "overstretched world wide despite the winding up of the Indian Empire and he was concerned to reduce our

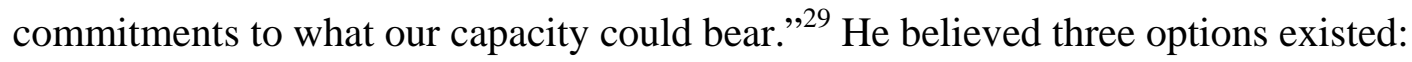
remain in the Canal Zone, liquidation of the British position, and treaty revision. Though the third option would ultimately entail liquidation, Eden was concerned that an instantaneous withdrawal hampered the British position in the region and damaged British authority. ${ }^{30}$ The situation in the Middle East had changed with Greece and Turkey entering NATO and a proposed Middle Eastern defense organization made the British more willing to negotiate with the Egyptians. Also, the advent of atomic weapons nullified the strategic importance of the Canal base since atomic weapons could easily eliminate large masses of troops and bases. The 1936 Treaty was no longer applicable since it was signed during a time of duress. The treaty was signed when Egypt was

${ }^{27}$ Eden, 245. For a description of the Egyptian revolution and the rise of Nasser see Marlowe, 381-403. ${ }^{28}$ Eden, 248.

${ }^{29}$ Evelyn Shuckburgh, Descent to Suez: Foreign Office Diaries 1951-56: From Churchill's Last Government to the Suez Crisis Under His Hand picked Successor Anthony Eden (New York: W.W. Norton \& Company, 1986), 17.

${ }^{30}$ Ibid., 256. 
threatened by foreign aggression and needed the British to protect Egypt from invasion. The Egyptians now had a large enough army and were free from any threats requiring British assistance. The canal was no longer threatened, the Palestine situation had turned Arab opinion against the British, and internal strife existed within Egypt. ${ }^{31}$ By vacating the canal, the British could redeem their image in the Arab world and maintain some influence. In 1954, a British delegation under Anthony Head concluded an agreement with the Egyptian Government providing for a two year withdrawal of British troops from the canal and the mutual respect for the 1888 Convention. ${ }^{32}$ The treaty was a matter of convenience for both governments since neither wanted to continue the current state of affairs. $^{33}$ The one weakness of the planned withdrawal was the state of belligerency between Egypt and Israel, which flared over the next two years. Without the British garrison acting as an impediment, there was a distinct possibility of the canal becoming a battlefield in a war between Israel and Egypt. The main reason for Britain’s withdrawal was financial since the British were still mired in post-war economic difficulties and the cost of supporting the Suez Base proved a heavy economic burden. ${ }^{34}$

The treaty had several noteworthy provisions. The most important was the withdrawal of British troops by $1956 .{ }^{35}$ It also provided for the maintenance of the base and the British use of the base in the event of an external attack on Turkey or the Arab

\footnotetext{
${ }^{31}$ Chester Cooper, Lion’s Last Roar Suez 1956 (N.Y.: Harper \& Row Publishers, 1978), 48.

${ }^{32}$ Eden, 260.

${ }^{33}$ Ibid., 261.

${ }^{34}$ Diary Entry 3-3-54 in Shuckburgh, 136.

${ }^{35}$ Article I of The Anglo-Egyptian Agreement of 1954 Regarding the Suez Canal Base in Schonfield, 198.
} 
League. ${ }^{36}$ Article VIII provided for the upholding of the 1888 Agreement and once again reaffirmed the strategic importance of the canal. ${ }^{37}$ The treaty devolved into a test run of Egyptian maintenance of the canal. Most importantly, the treaty allowed the British to use the base in times of trouble and the respect for the 1888 Convention allowed for the free transit of the canal and the continuous flow of oil, which was vital to the economies of Western Europe. Britain also had bases outside of Egypt in Aden, Cyprus, Malta, and Iraq, which allowed for the defense of the canal. The British envisioned the Baghdad Pact as a way to maintain the British presence in the region. Finally, the Canal Company still controlled the canal and thus the canal was still European. Churchill was not pleased with the development uttering "we have thrown our glorious empire away," he continued in office to save Eden from discrediting himself over Egypt. ${ }^{38}$ Churchill feared the canal handover would ruin Eden's political career and make Eden's candidacy as Prime Minister doomed to failure. Eden was pleased. He succeeded in maintaining the flow of oil, without which the British could not live and would be strangled to death. ${ }^{39}$ By the end of 1954, the situation in the Middle East appeared resolved and the threat of attacks on Britain minimal. The ascension of Eden to Prime Minister followed and Eden hoped to emerge from the shadows of Churchill to take the position he had long sought. Unfortunately, the Middle East troubles flared up during the Eden Ministry with Nasser and the Soviets attempting to rid the region of the British.

\footnotetext{
${ }^{36}$ Article V in Ibid., 199.

${ }^{37}$ Article VIII in Ibid.

${ }^{38}$ Diary Entries 1-18-54 and 4-24-54 in Shuckburgh, 127 and 173.

${ }^{39}$ Eden, 351.
} 
Many events in the Middle East came to a head and resulted in the Suez Crisis in 1956. At the time, Anthony Eden’s health deteriorated. In 1953 three operations had weakened him physically and Eden suffered from reoccurring jaundice. After thirty years of struggling with dictators, his mental abilities sagged. ${ }^{40}$ The diminished state of the Prime Minister figured into the rash decision making in the lead up to the Suez Crisis. Three main events laid the groundwork for the Suez Crisis: the Czech arms deal of 1955, the dismissal of Glubb of 1955, and the Aswan Dam proposal of 1956. In 1956, Eden held a summit with First Secretary of the Communist Party of the Soviet Union Nikita Khrushchev and Soviet Premier Marshal Bulganin in London. During the course of the meeting, Eden told the Soviet statesmen that "the uninterrupted supply of oil was literally vital to our economy ... and that we could not live without oil and we had no intention of being strangled to death." 41 This statement provided Eden’s logic for British actions during the Suez crisis. Eden’s Under Secretary in the Foreign Office Evelyn Shuckburgh described the British position in the Middle East in the early 1950s as follows:

We were the dominant power throughout the area. We had a huge military base on the Suez Canal, a naval base at Aden, air squadrons stationed in Iraq, rear bases in Cyprus and Malta; we paid for and provided the commander of the Arab Legion in Jordan. We had protectorates over Persian Gulf Sheikhdoms, whose foreign relations we conducted through a political resident in Bahrain. We had enormous oil investments in Iran and a growing interest in Gulf oil. All were under attack in one way or another. $^{42}$

\footnotetext{
${ }^{40}$ Terence Robertson, Crisis: the Inside Story of the Suez Conspiracy (N.Y.: Atheneum, 1965), 13.

${ }^{41}$ Eden, 358.

${ }^{42}$ Shuckburgh, 211.
} 
Shuckburgh was correct in his assertion and the British dominance of the Middle East was soon under siege. The forces of pan Arabism and Nasser targeted the British presence in the Middle East and called for the expulsion of Britain from the region. Conflict against British control in Cyprus, pro Nasser propaganda in Jordan, and the Abadan crisis in Iran had lessened the British stature in the region. In 1951, Muhammad Mussadeq, the Nationalist Prime Minister of Iran, nationalized the Anglo-Persian oil Company and the Abadan Oilfields. ${ }^{43}$ The British eventually negotiated a settlement with the Iranians rather than invading, thus showing an unwillingness to act with a strong hand. ${ }^{44}$

At the beginning of the Eden Ministry, the British position in the Middle East was relatively intact. Though the 1954 Agreement had called for the evacuation of British troops from the Canal Zone, the troops stayed in place for another year. Also, the British alliances with Iraq and Jordan appeared solid. But the intrusion of the Soviets into the region shattered this illusion. Additionally, the emergence of Nasser proved a great trouble to the Eden Ministry. Nasser was among the officers involved in the Revolution of 1952 and was widely acknowledged as the driving force behind the movement. ${ }^{45} \mathrm{He}$ was involved in underground activity since his days as a student and had distinguished himself in the 1948 Arab-Israeli War. ${ }^{46}$ Nasser became President, Prime Minister, and

\footnotetext{
${ }^{43}$ James, 563.

${ }^{44}$ James, 559-571 and Eden, 189-224.

${ }^{45}$ Marlowe, 387 and 405.

${ }^{46}$ Ibid., 405.
} 
Chairman of the Revolutionary Command Council on February $24,1954^{47}$ Nasser was in power during the 1954 Agreement and worked to remove the British from Egypt. However, Nasser's goal was leadership of the Arab world and the British sponsored Baghdad Pact proved a competitor and a challenge to Nasser. ${ }^{48}$ The trouble began on September 27, 1955 when Nasser announced an agreement to purchase arms from the Soviet Bloc through Czechoslovakia. ${ }^{49}$ Nasser reasoned that the 1950 Tripartite Declaration of Britain, France, and the United States, which prohibited any arms deal which would tip the military balance in the Arab-Israeli dispute, prevented access to prior sources of arms. Nasser found a ready supplier in the Soviet Union. This development led to the Soviets gaining a foothold in the most strategically important area of the Middle East in British eyes and an alliance with the most charismatic of Arab Leaders: Nasser. To combat and prevent the Soviet intrusion into the Middle East, the British attempted to build a security alliance covering the Middle East, the resulting alliance was known as the Baghdad Pact. ${ }^{50}$ The pact was built on the Turco-Iraqi alliance and grew to also include Britain, Iran, and Pakistan, forming a defensive shield against communism stretching from the Mediterranean to the Himalayas. ${ }^{51}$ The arms deal also rendered Egypt ineligible for the Baghdad Pact due to their perceived alliance with the Soviets and

\footnotetext{
${ }^{47}$ Ibid., 407.

${ }^{48}$ Ibid., 414.

${ }^{49}$ Eden, 330.

${ }^{50}$ Ibid., 219-223.

${ }^{51}$ Ibid., 223.
} 
Nasser's verbal attack on Nuri Said of Iraq and Glubb Pasha of Jordan. ${ }^{52}$ The attacks came about the same time as the visit of the Chief of the Imperial General Staff Sir John Templar to Jordan to aid in the renewed negotiations over the Anglo-Jordanian Treaty of Alliance. The dispatch of such a high ranking official to Jordan demonstrated the weakness of the British position. Templar had been sent to convince King Hussein of Jordan to place his country in the Baghdad Pact; his negotiations ultimately failed. ${ }^{53}$ Previously a simple word from the British ambassador in Amman or the Commander of the Arab Legion Glubb Pasha resulted in Jordan following British advice; but the highest ranking military official in Britain held no sway over a minor Arab monarch. While these events were disheartening to Eden, especially when coupled with the Czech arms deal, further events in Jordan would diminish the British standing in the Middle East and generate Eden’s fervent hatred of Nasser.

Beginning in 1952, Egyptian promoted Free Officer pamphlets espousing panArabism and anti-British messages began to appear in Jordan. ${ }^{54}$ In these pamphlets, their authors labeled Britain as the enemy and exploiter of the Arabs. ${ }^{55}$ Pan Arabism was the idea of a united Arab front against imperialism and the union of the Arab States. Nasser was the main proponent of pan Arabism and his allegiance to this doctrine endangered

\footnotetext{
52 Ibid., 330-5.

${ }^{53}$ Mohammad Heikal, Cutting the Lion's Tail: Suez Through Egyptian Eyes (N.Y.: Arbor House, 1987), 88.

54 John Glubb, A Soldier with the Arabs (New York: Harper \& Brothers Publishers, 1957), 411.

${ }^{55}$ Ibid., 411.
} 
the British position in the Middle East. ${ }^{56}$ Nasser took steps to unify with other Arab states and assume the mantle of Arab leadership, to do this he had to oppose the British and Israelis. By targeting the British presence in the Middle East, Nasser was able to portray himself as the defender of the Arab States and his position tended to rely on his opposition to Britain. The appearance of the pamphlets and the growing popularity of Nasser targeted Glubb, the commander of the Arab Legion, a symbol of British influence in the region, and one of the most powerful men in Jordan. On March 1 1956, the Prime Minister of Jordan summoned the British ambassador to the Palace to inform him of the King Hussein's s decision to dismiss Glubb. ${ }^{57}$ The rationale provided by the king was the constant references in the press to Glubb being the true power in Jordan and Eden believed the young monarch was jealous of Glubb. ${ }^{58}$ The aftermath witnessed the king and Nasser being cheered in the same breath. Additionally, the meeting between Nasser and Foreign Minister Selwyn Lloyd did little to alleviate suspicion. According to Mohammad Heikal, a Cairo editor and confidant of Nasser, when Lloyd and Nasser met and discussed the dismissal, Nasser was quite happy thinking the British had seen the anachronistic quality of Glubb’s role and removed him. ${ }^{59}$ Lloyd visited Egypt on his tour of the Middle East and India. Lloyd and Eden took the response to mean Nasser had a hand in the dismissal of Glubb. Eden was angry enough to consider reneging on the 1954

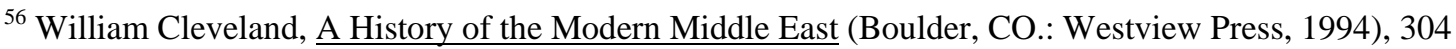
and 323.

${ }^{57}$ Eden, 347.

${ }^{58}$ Ibid., 348.

${ }^{59}$ Heikal, 97.
} 
treaty’s evacuation clause as way of countering the loss of Glubb. ${ }^{60}$ Eden compared Nasser to Mussolini earlier in the year and his hatred of the upstart Egyptian leader continued to grow. ${ }^{61}$ He blamed Nasser for all attacks on British interests in the Middle East and determined to alleviate the threat. ${ }^{62}$ In the following months, Eden informed visiting Soviet dignitaries of the British need of oil warning them that Britain would fight to protect her oil supply. By April 1956, a struggle between Eden and Nasser for dominance of the Middle East was brewing and Nasser's next move brought events to war footing. Nasser gained a free hand due to the removal of British forces from Egypt on June 131956 at 6:45 A.M. ${ }^{63}$ On that day the Union Jack was hauled down from the Navy House at Port Said and seventy years of occupation ended. ${ }^{64}$ Nasser was free to act without threat of immediate British retaliation despite his comments to Minister at Large Selwyn Lloyd stating, "we cannot understand why you are worrying about these matters now. We will be friends with when the attack comes. We will make a pact then." ${ }^{65}$ No pact was made.

At a cost of thirteen hundred million dollars, a fee the Egyptians could not meet, the Egyptian Government proposed the Aswan High Dam in 1955 to improve Nile Valley irrigation and develop hydroelectricity. ${ }^{66}$ The Egyptians appealed to the World Bank for

\footnotetext{
${ }^{60}$ Diary Entry 3-3-56 in Shuckborugh, 341.

${ }^{61}$ Diary Entry 1-29-56 in Ibid., 328.

${ }^{62}$ William Roger Louis and Roger Owen, Suez 1956: Crisis and Consequences (Oxford: Clarendon Press, 1989), 109.

${ }^{63}$ Schonfield, 146.

${ }^{64}$ Ibid.

${ }^{65}$ Lloyd, 15.

${ }^{66}$ Eden, 420.
} 
funding and Nasser seized upon the construction of the dam as a national goal. ${ }^{67}$ The British were concerned by Nasser's course of action if the project was not funded and feared that it might result in the possible seizure of the canal and disruption of European economic life. ${ }^{68}$ The main power behind the World Bank was the United States and the proposal was not popular in Congress. The publicity associated with the dam construction threatened to lead to exorbitant requests from other Arab countries. Eden commented on the effect of the dam on the Arab world by saying,

if there was to be charity, then friendly Arab countries had the right to apply. They could hardly be expected to view with enthusiasm the advance of large sums for an Egyptian project while the country was becoming ever more closely linked with Soviet Russia and while Egyptian propaganda was attacking both them and us. ${ }^{69}$

Essentially, giving aid to Nasser suggested rewarding his overtures to the Soviets.

Suspicions of Nasser and his ties to the Soviet Union led the Americans to pull out of the World Bank negotiations. Egyptian Ambassador Ahmed Hussein’s statement that if the United States would not fund the dam, then the Soviets would, proved the impetus for the withdrawal. ${ }^{70}$ United States Secretary of State John Foster Dulles believed Hussein’s statement to be a threat of blackmail and broke off the negotiations. ${ }^{71}$ With the option of

\footnotetext{
${ }^{67}$ Donald Neff, Warriors at Suez: Eisenhower takes America into the Middle East (New York: Linden Press, 1981), 244.

${ }^{68}$ Eden, 425.

${ }^{69}$ Ibid. 421.

${ }^{70}$ Robert Murphy, A Diplomat Among Warriors (Garden City, NJ.: Doubleday, 1964), 376-7.

${ }^{71}$ Ibid.
} 
World Bank funding revoked, Nasser turned to the only other funding opportunity available: the canal itself. On 26 July 1956, Nasser spoke in Alexandria and said,

We shall never repeat the past, but we shall eliminate the past by reclaiming our rights to the Suez Canal. This money is ours and this canal belongs to Egypt because it is an Egyptian limited liability company. We shall build the High Dam and we shall obtain our usurped right. We shall build the High Dam as we desire we are determined. Thirty five million pounds annually is taken by the Canal Company. Therefore I have signed today and the government has approved the following: a resolution adopted by the president of the republic for the nationalization of the Suez Canal. ${ }^{72}$

With this action, Nasser confirmed the worst fears and suspicions of the British

Government. The British had fought for the canal several times before to protect the route to India, now the issue was whether or not Britain would fight for their oil supply and influence in the Middle East.

The Egyptian seizure of the Suez Canal panicked and infuriated the British Government, particularly Anthony Eden. As historian John Darwin noted, the vital strategic waterway whose security had preoccupied British strategy since the 1870s passed under the direct physical control of a local power fiercely hostile to British influence. Full measure of British weakness became clear. ${ }^{73}$

Eden also saw an opportunity to deal with the upstart leader of Egypt and to end his challenge to British power. Upon hearing the news, Eden was furious and remarked "our whole position demands strong action. I want to seize the canal and take charge of it

\footnotetext{
${ }^{72}$ Neff, 271.

${ }^{73}$ Darwin, 211.
} 
again.”74 When informed that Nasser's action was legal, Eden showed his true hatred of Nasser by saying, “I don't care whether it’s legal or not, I 'm not going to let him do it ... he’s not going to get away with it."75 Though the canal was no longer under British protection and the nationalization was a perfectly legal maneuver, the perceived value of the canal precipitated a militant British reaction.

The British viewed the canal as vital to their well being due to its role in oil supply and regional influence. Eden identified three main concerns over the canal seizure. The first concern was that the "canal was an international asset and had been recognized as such ever since the Convention of 1888."76 Chancellor of the Exchequer Harold Macmillan believed that "such a flagrant breach of international convention would lead to a decline in international good faith reminiscent of world wars.”77 The development of Middle Eastern oil and the Western European reliance on the canal for oil transport provided another reason for the necessity of the canal to the empire. Finally, Eden believed the canal formed the centerpiece of British influence in the region. He remarked "failure to keep the canal international would inevitably lead to the loss one by one of all our interests and assets in the Middle East, and even if Her Majesty’s Government had to act alone they could not stop short of using force to protect their position."78 Eden viewed Nasser as the enemy of Western influence in the Middle East

\footnotetext{
${ }^{74}$ Neff, 276.

${ }^{75}$ Ibid.

${ }^{76}$ Eden, 426.

${ }^{77}$ MacMillan, Riding the Storm, 103.

${ }^{78}$ Eden., 426.
} 
and following in the footsteps of Hitler. ${ }^{79}$ The British had missed an opportunity to check the fascists before World War II and the acquiescence at Munich weighed heavy in their minds. This time they took no chances and on July 27 the Prime Minister instructed the Chiefs of Staff to prepare an invasion plan. ${ }^{80}$ The British would not sit back and watch their influence assaulted.

The British attempted to evict Nasser from the canal through diplomacy. On July 28, the British Government summoned a conference of maritime powers and froze Egyptian assets. ${ }^{81}$ The United States, Great Britain, and France participated at the conference. During the meeting Eden proposed direct action against Nasser and Robert Murphy of the United States State Department remarked, "it seemed impossible for Eden to keep in mind how much Britain’s power had diminished in relation to the United States and Russia. ${ }^{, 82}$ While the Americans viewed the crisis as an international matter and favored a diplomatic solution, the French sided with Britain and favored direct action. The French Government believed Nasser was supplying Algerian nationalists in their struggle with France. As a result France supplied weapons to the Israelis in hope of toppling Nasser. ${ }^{83}$ In deference to the Americans, Eden and the British Government agreed to convene a conference of the signatories of the 1888 Convention. The First London Conference was the beginning of several failed diplomatic initiatives to end the

\footnotetext{
${ }^{79}$ Lloyd, 81 and Eden, 441-2.

${ }^{80}$ Eden, 427.

${ }^{81}$ Eden, 433 and Randolph Churchill, The Rise and Fall of Sir Anthony Eden (London: MacGibbon \& Kee, 1959), 247.

${ }^{82}$ Murphy, 382.

${ }^{83}$ Eden, 435 and Neff, 161-4.
} 
crisis before hostilities commenced. Prior to the conference, Eden broadcast to the British people, "we cannot agree that an act of plunder which threatens the livelihood of many nations shall be allowed to succeed."84

While in public the British favored a political solution, the Chiefs of Staff formulated four methods of invading Egypt on August 3 with Alexandria and Port Said both targets. ${ }^{85}$ The London Conference began on August 16, 1956. The end result of the conference was a declaration for an international board including Egypt to oversee the canal and to maintain the canal as apolitical. A delegation headed by the Prime Minister of Australia Robert Menzies carried the conference resolution to Nasser. ${ }^{86}$ As the Menzies mission disembarked, the British Government pondered other diplomatic solutions and the prospect of military action. The Foreign Ministers of Belgium and the Netherlands, Paul Henri Spaak and Joseph Luns, argued for the NATO powers to refuse recognition of the canal seizure and Spaak believed if "the Western powers quailed, he foresaw a long series of retreats before them in Africa and the Middle East." ${ }^{, 87}$ Eden agreed with this view and had received reports from East Africa and Aden foreshadowing unrest in the Muslim world. ${ }^{88}$ The Menzies mission was in Egypt from September 2-9 and Nasser rejected the London Conference proposal for the Suez Canal, dismissing it as collective

\footnotetext{
${ }^{84}$ Eden, 444.

${ }^{85}$ Lloyd, 108.

${ }^{86}$ Eden, 452-3.

${ }^{87}$ Ibid., 458.

${ }^{88}$ Ibid.
} 
colonialism, and refused the overture due to infringements on Egyptian sovereignty ${ }^{89}$ Nasser and Menzies took an instantaneous dislike of one another and this poor relationship hampered negotiations. ${ }^{90}$ In a conversation with Menzies, Nasser stated What is your problem? ... Freedom of Navigation? I'm ready to discuss that. Tolls ? I'm ready to discuss that. The British press charges that I'm trying to build an empire? We can discuss that too if you want-but I will not discuss Egyptian sovereignty. Perhaps you would like to discuss British fears that I am going to cut off the lifeline of their empire? If I did that, it would mean war with Britain. Do you think I'm crazy enough to do that? And if I was so crazy how could the international board that you propose prevent me from doing that in any case. ${ }^{91}$

The failure of the Menzies mission served to exacerbate the situation between Britain and Egypt. Nasser did not appear open to diplomacy and was firmly aware of the accusations against him. Additionally, he was resolute in his unwillingness to permit any international authority over the canal or to give Britain an impetus for military action. Eden's use of diplomacy to resolve the crisis was failing.

During late August and September 1956, Eden not only had to balance the situation with Nasser, but also domestic opinion on the canal seizure and the Atlantic Alliance. The British Government believed that "every day Nasser was strengthening his hold on the canal. The Western powers would lose face unless they could react clearly and speedily to his rejection of the eighteen power proposals." ${ }^{\text {"92 }}$ The problem was with Nasser backed by the Soviets, the British needed the Americans on their side and it was

\footnotetext{
${ }^{89}$ Ibid. 472-3.

${ }^{90}$ Heikal, 147-53.

${ }^{91}$ Neff, 302-3.

${ }^{92}$ Eden, 476.
} 
difficult to make out where the Americans stood. ${ }^{93}$ Additionally, it was an election year and the American diplomats were under instructions to oppose intervention, so as not to hinder Eisenhower's reelection chances. ${ }^{94}$ The Americans also espoused an anti-colonial rhetoric and the possible embarrassment of association with a perceived imperial intervention threatened their standing in the struggle with the Soviets. By the time Nasser rejected the London Conference proposals carried by the Menzies mission, the Americans had proposed another diplomatic solution: the User's Club. While the Americans were avoiding any intervention, the British public took a different view.

The British Public and the Suez Group forced Eden to gravitate between two different solutions to the Suez Crisis. In a British Institute of Public Opinion poll on Military Action in Egypt taken from August 16-24, 1956, thirty-three percent of British citizens advocated military action against Nasser. ${ }^{95}$ A September 5-6, 1956 poll on the issue of an ultimatum with possible invasion, thirty four percent of those surveyed advocated the ultimatum and forty-seven percent of Conservatives surveyed. ${ }^{96}$ The polls indicated a lack of decision on the part of the British public, which favored economic and political sanctions. While the public was not ready for war, a group within Eden's own party was. The Suez Group was a group of Conservative back benchers still bitter over Britain's imperial retreat and who "thought that Britain would amount to very little in the

\footnotetext{
93 Ibid.

${ }^{94}$ Lloyd, 131.

${ }^{95}$ British Institute of Public Opinion Poll August 16-24, 1956 in Epstein, 142.

${ }^{96}$ British Institute of Public Opinion Poll September 5-6, 1956 in Ibid.
} 
world if it could not exert effective leadership of a larger unit." ${ }^{, 97}$ The Suez Group believed British dominance of the Middle East was the main claim Britain could make to world power status. Without this dominance, the British world position would lessen. The group also believed the Indian withdrawal to have been predicated on the continued British presence in Egypt and did not favor further British withdrawals in the Middle East. ${ }^{98}$ The Suez Group wanted action against Nasser as a way to avoid another British imperial retreat. When the crisis began the Suez Group jumped at the opportunity to weaken Nasser and to reassert the British dominance in the Middle East. As the crisis dragged on, it became more and more apparent that Eden would have to choose between direct action or giving in to Nasser.

As Egyptian control of the canal entered its second month in September 1956, the British struggled with American insistence on a diplomatic solution. United States Secretary of State John Dulles proposed the formation of a Suez Canal User’s Club (SCUA) to work to implement the 1888 Convention, cooperate with Egypt, and prevent canal traffic from coming under political influence. ${ }^{99}$ A conference of the proposed SCUA was called in September 1956 in London. The House of Commons met on September 12 to discuss the Middle East and the Labour party asked Eden to refer the issue to the Security Council or the International Court of Justice. ${ }^{100}$ The reason for the hostile nature of Labour's attack were comments by both Dulles and President

\footnotetext{
${ }^{97}$ Epstein, 53.

${ }^{98}$ Neff, 55.

${ }^{99}$ Lloyd, 132.

${ }^{100}$ Ibid., 140.
} 
Eisenhower stating they did not wish to see Britain shoot their way through the canal. ${ }^{101}$ The Americans forced the British to agree to the SCUA proposal to preclude the use of force, though the only measures of enforcement the club had were asset freezing and rerouting. The existence of enforcement measures provided the difference between the London Conference proposals and the SCUA. The possibility of re-routing allowed Nasser to get away with his theft and would hinder the oil supplies of Western Europe: Nasser would win. ${ }^{102}$ Nasser termed the SCUA an association for waging war and accused the eighteen powers of the First London Conference of "international thuggery and imperialism.”103 Nasser objected to the SCUA due to his belief that the canal was an Egyptian possession and should not be subject to international control. The dispute shaped up to be one of imperialism versus nationalism with Britain as aggressor. Worst of all for Eden, the Egyptians proved effective at running the canal. While the SCUA was scuttled by Nasser's refusal, the issue went to the United Nations.

On September 26, 1956, Eden and Lloyd flew to Paris and conferred with their French counterparts. The French had shown themselves to be Britain's staunchest ally in the canal dispute. Eden assured the French that British Government had not abandoned their objective of removing the canal from the control of a single government, preserving efficient navigation, and to prevent the Middle East from coming under Soviet

\footnotetext{
${ }^{101}$ Lloyd, 129 and Eden, 483.

102 Eden, 479.

103 Eden, 486.
} 
domination. ${ }^{104}$ The two governments agreed to coordinate their position in the upcoming Security Council debate. Eden also added that the Egyptian attack on treaties had endangered international confidence. ${ }^{105}$ On October 1 , the inaugural meeting of the SCUA occurred in London and the discussion of the canal nationalization began at the United Nations Security Council. A British sponsored resolution was debated on October 13 and entailed six principles on which settlement must abide,

1. There should be free and open transit through the canal without discrimination, covert or overt.

2. The sovereignty of Egypt should be respected

3. The operation of the canal should be insulated from the politics of any country.

4. The manner of fixing tolls and charges should be decided by agreement between Egypt and the users.

5. A fair proportion of the due should be allotted to development

6. In case of disputes, unresolved affairs between the Suez Canal Company and Egyptian Government should be settled by arbitration. ${ }^{106}$

The Security Council adopted these six principles unanimously, but the second part of the resolution proved difficult. ${ }^{107}$ The operative portion called for the governments of Britain, France, and Egypt to continue their interchange, free passage to all shipping, the payment of SCUA member dues to the SCUA, and Egyptian cooperation in canal management. ${ }^{108}$ The Soviet Union vetoed the second part of the resolution. The British wanted a settlement to preserve the international character of the canal and had tried several

${ }^{104}$ Ibid., 496.

${ }^{105}$ Ibid., 497.

${ }^{106}$ Ibid., 504.

${ }^{107}$ Lloyd, 162.

${ }^{108}$ Eden, 504. 
diplomatic solutions. Nothing had worked and Nasser still controlled the canal. Another option had to be pursued.

By the middle of October 1956, diplomacy had failed the British government. Nasser rebuffed the First London Conference and the Menzies Mission, he viewed the proposals as an infringement upon Egyptian sovereignty. The SCUA lacked any power of enforcement and would hurt Western Europe more than Egypt, but it too was dismissed by Nasser as international thuggery. The United Nations Security Council agreed upon the six principles of settlement for the crisis, but the resolution was vetoed by the Soviets. The Suez Group lobbied Eden to act with authority in the Middle East and the French were willing to support the British. The British public, though not favoring immediate military action, desired a settlement of some form. Finally, Nasser’s reputation and celebrity in the Arab world grew with each day he defied the British. In his September response to the Menzies mission, Nasser had stated he would not enter into hostilities with the British. Were the British to attack Egypt, the move would be perceived as imperialistic throughout the world and would risk losing American support. Eden had exhausted all diplomatic options and military action was becoming the best solution.

The British still publicly claimed to respect international agreements and the desire to preserve free navigation of the canal as their goal. As long as Nasser effectively ran the canal, little chance existed of these goals allowing military action. Events in the Middle East brought matters to a head. The Israeli raid on Gaza in 1955 had heightened 
border tensions between Israel and Egypt. ${ }^{109}$ Nasser’s flow of arms from the Eastern Bloc and the subsequent arms flow to Syria pointed to a coming Arab-Israeli war. Egypt also attempted to enlist Jordan, with whom the British had a defense treaty, into an alliance and pro-Nasser elements had emerged victorious in the Jordanian elections of $1956 .{ }^{110}$ On October 10, 1956, Israeli troops entered the Jordanian village of Qalqiya, killing forty eight Jordanians before they withdrew upon the arrival of the Arab Legion. ${ }^{111}$ The raid was in response to Palestinian raids into Israeli territory. Not only did Israel benefit from a superior army, but since 1955 they had been receiving a steady supply of French armaments and equipment. ${ }^{112}$ The situation in the Middle East was dangerous. The Israelis had taken military action against both Egypt and Jordan within two years. In the event of an Israeli attack on Jordan, Britain was treaty bound to honor her alliance with Jordan. If Israel attacked Egypt, the safety of the canal would be jeopardized. No matter which course the Israeli Government took, Britain would be involved.

In late October 1956, two momentous events in Cold War history occurred. On October 23, 1956 the first reports of the disturbances in Hungary appeared and on October 25, the British Government received a report that the Israeli army was mobilizing. ${ }^{113}$ On October 29, the Israeli army moved into the Sinai Peninsula and

\footnotetext{
${ }^{109}$ For a description of the raid see Neff, 218-220.

${ }^{110}$ Eden, 511-512.

${ }^{111}$ Neff, 331.

112 Ibid., 235.

${ }^{113}$ Eden, 521-522.
} 
attacked Egyptian positions. ${ }^{114}$ The beginning of the Israeli attack on Egypt yielded a great historic debate over the collusion between the British, French, and Israel and the socalled Sevres Protocol. Historian Terrence Robertson was one of the first to assert this theory and believed that the Israeli attack was orchestrated to allow the Anglo-French invasion. ${ }^{115}$ Historian Donald Neff subscribed to this view and accepted the collusion as accepted fact in his work, allowing for a greater portrayal the Suez Crisis as a colonial action. ${ }^{116}$ Selwyn Lloyd vehemently denied any collusion and though Eden believed the Israelis to have cause for the attack, made no mention of the Sevres Protocol. ${ }^{117}$ Recent scholarship has confirmed the collusion and no source more vividly illustrates the extent of the plotting as Edward Heath’s The Course of My Life: My Autobiography. ${ }^{118}$ The course of the collusion is at times convoluted, but when looked at as a whole describes the last great peak in the British attachment to the Suez Canal.

The beginning of the collusion occurred on September 10, 1956 with the arrival of French Premier Guy Mollet and Foreign Minister Christian Pineau in London for crisis talks. ${ }^{119}$ The French favored direct airborne action against Nasser and Eden agreed since an attack on Cairo would not be received well in the world political climate. ${ }^{120}$ The Americans were vehemently against military action and realized that an increase in oil

\footnotetext{
${ }^{114}$ Ibid.

${ }^{115}$ Robertson, 132-174.

${ }^{116}$ Neff, 342-348.

${ }^{117}$ Lloyd , 242-250 and Eden 522.

${ }^{118}$ Edward Heat, The Course of My Life: My Autobiography (London: Hodder and Staughton, 1998).

${ }^{119}$ Robertson, 108.

${ }^{120}$ Ibid.
} 
exports from the United States, Venezuela, and Canada coupled with redirection of tankers round the Cape Route would sustain European oil: the strangulation argument was debunked. ${ }^{121}$ In addition, Eisenhower was not prepared to commit the United States to military action over the canal. The British and French tried to force the issue of military action by having the Suez Canal Company order its pilots off the job on September 14, but the Egyptians proved more than capable of running the canal ${ }^{122}$ On September 12, 1956, Eden announced in Commons that Britain would take action if Egypt ignored her obligations under the 1888 Convention. ${ }^{123}$ The problem was the Americans did not back the British and John Foster Dulles denied American support for any British plan to "shoot their way through the canal. ${ }^{124}$ Dulles' statement effectively gave Nasser the victory since without American support and unprovoked European assault appeared impossible. Meetings in Paris proved Nasser wrong.

On September 23, 1956 Israeli Foreign Minister Shimon Peres was in Paris for talks and Pineau flew to London to raise the possibility of collusion with the Israelis. If Israel attacked Egypt, the British and French could go in as peacekeepers. Eden was quite intrigued by the proposition, but Selwyn Lloyd was apathetic, more concerned about the effect on Britain’s Middle East position. ${ }^{125}$ On September 20, Eden and Lloyd flew to Paris to allegedly discuss the European Free Trade Area, but went to plan the assault. In

${ }^{121}$ Ibid. 110.

${ }^{122}$ Ibid., 110-120.

${ }^{123}$ Ibid., 116.

${ }^{124}$ Ibid., 119 .

${ }^{125}$ Ibid., 135 
order to cover their tracks, Britain announced that Her Majesty’s Government would honor her treaty obligations with Jordan, if Jordan were attacked by Israel. ${ }^{126}$ Britain appeared to be anti-Israeli and the possibility of war in the Middle East pointed to an Israeli-Jordanian affair. On October 23, 1956, the Sevres Protocol was signed calling for Israeli to attack Egypt and the French to veto any anti-Israeli resolutions in the United Nations. ${ }^{127}$ Eden consented to this agreement and the planned ultimatum and invasion appeared set in stone. Eden was determined that Nasser and his regime must be brought down. ${ }^{128}$ Upon the signing of the agreement, Eden gathered Lloyd, Macmillan, and Chief Whip Edward Heath together and stated “we’ve got an agreement Israel had agreed to invade Egypt. We shall then send in our forces backed up by the French, to separate the combatants and regain the canal."129 Such was the resolve of Eden to defend the canal that he conspired to regain control through subterfuge.

Upon receiving the news of Israeli mobilization, the British Cabinet decided that in the event of hostilities, Israel would defeat Egypt. The issue was how to protect the canal. The Cabinet decided that in such an event, France and Britain would call upon both parties to cease hostilities, withdraw a certain distance from the canal, and intervene if one side refused compliance. ${ }^{130}$ By October 30 , the Israelis were halfway to the canal and the possibility of the canal becoming a battle ground existed, in violation of Article

\footnotetext{
${ }^{126}$ Ibid., 146.

${ }^{127}$ Ibid., 166.

${ }^{128}$ Heath, 169.

${ }^{129}$ Ibid.

${ }^{130}$ Eden, 523.
} 
IV of the 1888 Constantinople Agreement. A possibility also existed of Jordan and Syria joining the war and Eden decided that the arrival of British troops would prompt these two countries to inaction. With the United Nations and several diplomatic conferences having failed, the ultimatum was the best course of action. On October 30 1956, the British Cabinet met and decided to issue the ultimatum and Eden announced the decision to the House of Commons at 4:30 P.M, by saying "that the French and British Governments were agreed that everything should be done to bring hostilities to an end." ${ }^{\text {131 }}$ The ultimatum called for a cessation of hostilities and the two sides to withdraw ten miles from the canal. He further announced that the purpose was to separate the belligerents and guarantee the free navigation of the canal. ${ }^{132}$ He described the possible occupation of the canal area by British and French troops as temporary and Eden announced a Security Council meeting would be sought immediately. On the evening of October 30, the Security Council met and the United States proposed a resolution calling for an immediate end to hostilities, an Israeli withdrawal, and urging all members to restrain from force. ${ }^{133}$ The proposed resolution took away the British ultimatum and proposed nothing in its place; this proposal resulted in the first British use of her veto power on the council. A subsequent Soviet resolution was vetoed by Britain and France, the ultimatum had been issued and the British were not going to let the American and Soviet resolutions counteract it. The veto was in keeping with the Sevres Protocol. The

\footnotetext{
${ }^{131}$ Ibid., 527.

${ }^{132}$ Ibid.

${ }^{133}$ Ibid., 529.
} 
Egyptians rejected the ultimatum and on October 31, the British agreed to commence air attacks on the Egyptian air force. ${ }^{134}$ On November 1 at 10:29 P.M., Selwyn Lloyd announced the commencement of hostilities in the House of Commons. ${ }^{135}$

The British prepared for an invasion from the outset of the crisis and forces had been standing ready since mid-September. The plan called for four phases. The first phase consisted of the elimination of the Egyptian air force followed by the second phase, air attacks on Egyptian military installations. The third phase was an airborne landing in the canal zone followed by a seaborne landing at the opening of the canal. While a lack of landing craft hampered the invasion plan, it was incalculable that Egypt would stand up to the combined force of Britain and France. The attacks had an opposite effect. Allied air attacks stiffened Egyptian resolve and morale, Nasser broke diplomatic relations with Britain and France, ordered all British and French citizens to register with authorities within three days, and most importantly ordered the blockage of the canal. ${ }^{136}$ The very reason for British intervention was at risk and Nasser was not backing down. On November 1, Radio Cairo announced the sinking of fifty ships thereby blocking the canal. ${ }^{137}$ On November 3, 1956 Egypt's ally Syria broke diplomatic relations with Britain and France and blew up the Iraqi Petroleum Company pipeline crossing Syria. ${ }^{138}$ The objectives of Eden's Government were defunct. The oil supply to Europe was

\footnotetext{
${ }^{134}$ Ibid., 532.

${ }^{135}$ Neff, 384.

${ }^{136}$ Ibid., 393-4.

${ }^{137}$ Ibid.

${ }^{138}$ Ibid., 398.
} 
blocked by the ships in the canal and the pipeline sabotaged. The preservation of free navigation through the canal was impossible. The British influence in the Middle East dwindled due to her perceived alliance with Israel and Nasser's growing popularity stemming from his defiance of Britain. The battle continued in the field and in the political sphere.

While events on the ground went against the British, the Labour Party and the United Nations also assailed the British decision to use force. Near fisticuffs characterized the Commons debate on November 1 and Eden was booed and greeted with cries that he should resign. ${ }^{139}$ Labour Member Aneurin Bevan accused the Eden Government of bullying Egypt and acting towards Egypt as the Nazis had towards Norway. A motion of censure failed and Eden survived on party lines. ${ }^{140}$ On November 2 the United Nations General Assembly, operating under the Uniting for Peace Plan, debated events in Egypt with the United States leading the diplomatic attack on Britain. The Uniting for Peace Plan was a United Nations maneuver which allowed a debate to be sent from the Security Council to the General Assembly, where no vetoes were applicable. The resolution called for an immediate cease fire, a prohibition of further military goods into the area, and an emergency session of the General Assembly until the crisis was over. The resolution passed sixty-four to five, only Britain, France, Israel, Australia, and New Zealand voted against the resolution. ${ }^{141}$ Eden announced to

\footnotetext{
139 Neff, 389.

${ }^{140} \mathrm{Ibid}$.

${ }^{141}$ Eden, 542.
} 
Commons that the British were not prepared to halt their action as long as hostilities continued and the Anglo-French forces would hand over their position to a United Nations police force if created. ${ }^{142}$ On November 4, the Cabinet met to discuss the progress of the land invasion as the Canadian delegation to the United Nations drafted a resolution for the formation of a UN police force. ${ }^{143}$ The problem was the Israelis had already taken the Sinai by November 3 and the Egyptians had retreated from the Peninsula. Without a United Nations force, Eden decided to proceed with the invasion and Britain and France announced they were landing troops to assure the withdrawal of Israeli troops from Egypt. ${ }^{144}$ David Ben-Gurion was outraged at the statement and announced Israeli acceptance of the cease fire. ${ }^{145}$ On November 5, the airborne landing began and on November 6, the seaborne landing occurred. ${ }^{146}$ With Israel and Egypt having accepted the ceasefire, Eden announced to Commons, "Her Majesty's Government are ordering their forces to ceasefire at midnight GMT unless they are attacked. ${ }^{\not 147}$ British forces were in a position to seize the canal, but Eden lost his resolve due to British economic difficulties. French Foreign Minister Christian Pineau recalled, “ I hear a broken voice that of a man who has exhausted the limits of his own resistance

\footnotetext{
${ }^{142}$ Ibid.

${ }^{143}$ Eden, 550; for full details of the diplomatic initiatives of the Canadian delegates see Robertson, 137377.

${ }^{144}$ Neff, 402.

${ }^{145} \mathrm{Ibid}$.

${ }^{146}$ Eden, 552-3.

${ }^{147}$ Neff, 413.
} 
and is ready to let himself drown. In substance he says, it is no longer possible, we must stop, the pound has dropped again we risk panic."

The British involvement in the Suez War lasted five days. Casualties proved minimal and the Government had deployed over ten thousand men to Egypt, but events spiraled out of Eden's control. Three main forces ended the British action: oil, the British economy, and world opinion. The canal blockage and pipeline detonation hampered the oil reserves of Britain and rationing had to be imposed. ${ }^{149}$ The cost of the invasion brought economic troubles with gold and dollar reserves falling fifty seven million dollars in September, eighty-four million in October, and three hundred nine million in November, Britain needed dollars to purchase oil from alternative sources. ${ }^{150}$ The British pound was dependent on the American dollar and, despite financial crises in the late 1940s, de facto convertibility of transferable sterling had been achieved. ${ }^{151}$ The British Government strove to make the pound convertible into gold and dollars, but the position of the pound was precarious. As early as August 1956, the British financial officials feared attacks on the pound or curtailed oil supplies would hamper the pound. ${ }^{152}$ Both these fears were realized. Numerous Arab countries refused to sell oil for pounds and the British had to use dollar reserves to purchase oil. ${ }^{153}$ The pound devalued as gold and

\footnotetext{
${ }^{148}$ Ibid., 416.

${ }^{149}$ Ibid., 424.

${ }^{150}$ Ibid.

${ }^{151}$ Diane B. Kunz, "The Economic Diplomacy of the Suez Crisis,” in William Roger Louis and Roger Owen, Suez 1956 The Crisis and Its Consequences (Oxford: Clarendon Press, 1989), 216-219.

${ }^{152}$ Ibid.

${ }^{153}$ Ibid.
} 
dollar reserves plummeted as the Bank of England tried to maintain convertibility and the pound began to lose value. ${ }^{154}$ The only way to salvage the British economy was from outside aid. With the devaluing of the pound, the only currency stable enough to bail out the British was the dollar, but the Americans were not in a generous mood. The only available source of aid was the Americans and they would not discuss economic aid until the British troops withdrew, which they did on December 22. The Egyptian Government also would not contemplate clearing the canal until the British withdrew from Egypt. ${ }^{155}$ The Middle East ceased to look to Britain for guidance and the Soviets and Americans entered the region. The Soviets gained a foothold in the Middle East and soon signed arms deals with Iraq, Syria, and Libya. Nasser gained immense popularity and became an Arab hero. The statue of Ferdinand de Lesseps at Port Said was dynamited on December 24 and the Egyptians removed the last vestige of European control of the canal. ${ }^{156}$ Eden resigned as prime minister shortly after the crisis and his successor Harold Macmillan oversaw the break up of the empire. The Iraqi Government of Nuri Said, the most pro-British of Arab statesmen, fell in 1958 and Said and the royal family of Iraq were murdered. ${ }^{157}$ With the assassination of Said, the last foothold of the British in the Middle East disappeared.

The collusion had backfired and events following the cease fire acceptance and an appraisal of the Suez Crisis are described by Edward Heath,

\footnotetext{
${ }^{154}$ Ibid., 226.

${ }^{155}$ Eden, 565.

${ }^{156}$ Schonfield, 160.

${ }^{157}$ Eden, 577.
} 
Eden told his cabinet secretary on 14 December to destroy all relevant documents and the Sevres Protocol. Despite later revelations, Eden never changed his position. At the time he was absolutely convinced that the prevention of a dictator getting his own way was in the interest of Britain, the Middle East, and the world as a whole. He considered it essential to safeguard world peace and the vital trade routes of ourselves and our friends. The fact that we managed for so long after the canal was closed with the alternative route around the cape, and developed carriers of larger tonnage for that purposed proved how wrong that premise was, but it does not alter the genuine nature of his concern. Similarly, the fact that once the canal was opened, the Egyptians were able to run it so easily contradicted all the previous assertions that an international consortium was essential for operational purposes if traffic through the canal was to survive. But that was a genuine belief at the time. Eden also claimed that introducing international control backed by international forces into the Middle East would limit Nasser's power and this was a future safeguard against any future expansionist ideas from him. The fact that later his expansionism led him into Yemen and into treaties with Syrian and Libya rather counter this claim. ${ }^{158}$

While Heath, believed the operation was a failure and fiasco, Lloyd and Eden took a different view.

Eden believed the operation was a success and prevented the establishment of a pan-Arab empire. ${ }^{159}$ He noted the Israeli access to the canal and the prevention of Egyptian control of both sides of the canal. The latter portion is in error since the Egyptians controlled both sides of the canal until 1967. Selwyn Lloyd provided a balance sheet of the crisis in his memoirs. He believed that negative results from the crisis existed: diplomatic defeat, failure to establish international control of the canal, the failure to enhance an Arab-Israeli settlement, and the psychological blow of the defeat to

${ }^{158}$ Heath, 177.

${ }^{159}$ Eden, 577. 
the British people. ${ }^{160}$ Two of the three negatives identified by Lloyd for British actions in Suez were accomplished: the prevention of a general conflagration of hostilities and the checking of Nasser. ${ }^{161}$ Lloyd also contended the events of 1956 did not detract from British influence in the Middle East and led to closer Anglo-American cooperation. ${ }^{162}$ The enhanced Anglo-American cooperation derived from the British realization that it was impossible for Britain to act in opposition to the Americans. The British viewed cooperation with the Americans as a sure way to avoid the mistakes of 1956 . The end result was the relegation of Britain from world power status. While Eden and Lloyd are correct in the beneficial aspects of Suez, the strengthening of the Atlantic alliance and the checking of Nasser, the events of 1956 had three main results for the British. First, the only claim Britain had to world power was as an ally of the Americans. Secondly, British hegemony in the Middle East was replaced by a Soviet-American struggle for hegemony with Britain playing the role of outlier. Third, the war exposed the weakness of the British Empire and the victory of Nasser led to similar leaders arising throughout the world demanding independence from the British Empire. Finally, the results of the crisis forced Anthony Eden, the heir to Churchill and the imperial symbolism associated with that title, from office and the result was the Conservative Party oversaw the dissolution of the British Empire. As Chester Cooper, a member of the CIA during the crisis observed,

In three bitter wars British forces had met and vanquished formidable enemies near the Nile. Napoleon, Kaiser Wilhelm,

\footnotetext{
${ }^{160}$ Lloyd, 251-253.

${ }^{161}$ Ibid., 248-9.

162 Ibid., 254-257.
} 
Mussolini, and Hitler each tried to gain control over the Isthmus of Suez; each suffered defeat. But the combined forces of Britain and France met with disaster after one short week in their effort to regain control of the Suez Canal from Nasser and his third rate army. 163

The events of Suez did not result in the immediate end of the British Empire, but weakened British world standing and allowed the beginning of the process of decolonization. No longer would Britain dictate politics in the Middle East and no longer would the British control the canal. The eighty one year attachment had ended.

The Suez Crisis and the Sevres Protocol represented the last peak in the imperial attachment to the canal. In the prior two phases, the power of the British Empire allowed for direct action to safeguard the canal. However as British power waned, the attachment to the canal remained unaltered. Eden used the reasons of oil supplies and the Soviet threat as legitimizations for the actions during the Suez Crisis, but neither was valid enough to necessitate the behavior of the British Government. Pressure from the Suez Group, the public, and the British past mandated that the canal remain British or belong to no other country. The canal held a hallowed place in the imperial worldview and to forfeit possession of the canal to a former holding was analogous to forfeiting any British claim to world power. Eden and many in his party saw the canal as the last possession of influence Britain controlled in the changing world political scene. Such was the deep rooted attachment to the canal that Eden risked the vitality of empire, the British economy, and his own career to maintain British control, or at least influence, over the

${ }^{163}$ Chester Cooper, The Lion’s Last Roar Suez 1956 (New York: Harper \& Row Publisher, 1978), 203. 
canal. Like Disraeli, Gladstone, and Churchill before him, Eden wanted to maintain the imperial attachment to the canal and avoid the shame of being the Prime Minister who lost this vital artery. Eden alienated Britain’s American and Arab allies and sounded the beginning of the end of the British Empire. Eden risked his political career and the empire on reclaiming the canal, unfortunately Eden lost. The importance attached to the canal sounded the end of the empire. In the past, Britain had fought to protect the canal and been successful in defending the canal. The canal was the lifeline of the empire, or so it was thought. The attachment to the canal was so great and entrenched that Eden knew he had to act and believed his actions were justified, even the collusion. Unfortunately, Eden's actions served to hamper the empire and show the world the waning of British power. 


\section{Chapter V}

\section{Conclusion}

Successive British Governments from Disraeli to Eden viewed the Suez Canal as a vital part of the British Empire. The French invasion of Egypt in 1798 and the Great Revolt had demonstrated the need for the empire to control or at least dominate the Middle East to protect the empire. The Suez Canal represented not only a great benefit to British trade but a vital cog in imperial security. Control of the canal meant control of the Middle East, the safety of the Indian Empire, and later the protection of oil supplies to the empire. Britain depended on the region to maintain the vital artery between the Home Islands and India. The canal was the scene of great British victories and the gateway to the exotic lands of the empire. Disraeli felt he achieved a great coup by the purchase of the canal shares in 1875 and, despite doubters at the time, he was correct. The imperial attachment to the canal endured several shifts from 1875 to 1956, but one constant remained: the empire needed the canal.

Beginning in 1875, the canal occupied a central role in the strategy of the British

Empire. The danger of a French controlled canal astride the route to India was too grave a danger for imperial strategists to allow. The British established themselves as the prime beneficiary of the canal in the early 1870s and gained a say in the running of the Suez Canal Company. Despite an initial fear of entanglement in Egypt, the British used the 
canal for economic benefit in the early 1870s. Khedive Ismail's attempts at Westernization and the negative effects of these projects on Egypt's finance, plus worries of European financial ties with Egypt forced the British to take a direct role in the government of Egypt through the 1877 Dual Control. The subsequent Arabi Revolt in 1882 and British occupation served to demonstrate the importance the British attached to the canal. The threat of anarchy and lawlessness in the canal area prompted the Gladstone Government to take action. While explained as an invasion to restore order, Gladstone admitted to Lord Ripon that "apart from the canal we have no interest in Egypt." ${ }^{1}$ A temporary occupation began and lasted until 1956. The first phase of the imperial attachment to the canal saw the British position along the canal threatened by several European powers and identified as the achilles' heel of the empire. Nonetheless, controlling the canal or preventing others from controlling the canal became a bulwark of British imperial defense policy.

The period from 1914 to 1945 was characterized by British vacillation over the importance of the canal. The British garrisoned and defended the canal in World War I. The canal was the scene and starting point of the only purely British victories of World War I and it was intimately associated with the actions of Allenby and Lawrence of Arabia. The British territorial acquisitions after World War I created a new area of imperial rule with the canal as the centerpiece. Such was the British attachment to the

\footnotetext{
${ }^{1}$ Gladstone to Lord Ripon 9-6-1882 in H.C.G. Matthew ed., The Gladstone Diaries with Cabinet Minutes and Prime Minister's Correspondence, Volume X January 1881 to June 1883 (Oxford: Clarendon Press, 1990), 327.
} 
canal that the British Government insisted that British dominance over the canal be written into the peace treaties after World War I. The importance of the canal grew with the pending independence of Egypt and the British Government refused to hand over the canal to the Egyptians, citing the issue of the canal as one of the four points of reservation for Egyptian independence. The interwar period saw a temporary retreat from the traditional view of the canal. The base at Singapore and the prospect of war with Japan rendered the canal expendable and allowed Egyptian defense to become dilapidated. Only when Italy threatened the British dominance of the canal was the Mediterranean once again termed the first battlefield of Britain. The canal occupied a central role in the North African Campaign with the Axis forces attempting to seize the canal and British forces preventing the loss of the canal. The victories of Montgomery and the Eighth Army were tied to the canal. Without the canal, no British troops would have been in the region. In both World Wars, the canal was used to transport imperial troops to defend the empire and was the scene of the forces of the empire rallying to defeat the enemies of the crown.

The last phase of imperial attachment stretched from 1945 to 1956 . Similar to the second phase, the canal went through a period of de-emphasis. The Atlee Government wanted to hand over the canal and believed that there was little use for the British base at the Canal Zone. The development of nuclear weapons and the weakness of Britain in comparison with the Soviets and Americans necessitated the empire cutting its losses. The failure of the Sidqi-Bevin talks and the loss of Palestine, though, re-emphasized the 
importance of the canal. The British Empire might have lost India, but new importance was found for the canal. The canal was the most important strategic holding in the Middle East, the one part of the globe where Britain was paramount. It also represented a base from which the British could meet Soviet advances and play an active role in the Cold War. Finally, the oil shipped through the canal represented the existence and survival of Western Europe. The Suez Crisis of 1956 demonstrated the lingering attachment to the canal and the continued British reluctance to accept anything other than British control of the canal. When Nasser nationalized the canal, the British Government began planning an invasion despite its weakened power. The Eden Government even went as far as to engage in collusion to protect the canal. The end of the Suez Crisis and the blocking of the canal formed the last gasps of the imperial attachment, after which the British ceased to play a role in canal operations and, to a huge extent, ceased to be a world power.

This thesis proposed to show the continued imperial attachment to the canal. Some historians view the history of British-Suez Canal policy as a scattering of events dictated by larger world events. This view is simply not the case. The British Government and British Foreign Policy linked themselves to the security of the Suez Canal. In the first phase of attachment, the canal was viewed as necessary to protect the Indian Empire and guarantee British trade, both sources of British world power. British power became linked to the canal from 1875 to 1914 and the canal guaranteed imperial trade and security. The second phase from, 1914 to 1945 showcased the importance and continued 
presence of the canal in British Imperial Strategy and policy. Both World Wars saw the British devote thousands of troops to the protection of the canal. The British risked their world status and even the empire on one last attempt to protect the canal in the third phase of its history. Essentially, the imperial attachment to the canal proved to be more than a series of isolated events. Instead, the imperial attachment to the canal began with the opening of the canal and the realization of the strategic and economic importance of the canal for the vitality of the empire. When the initial reason of Indian security ended in 1947, the British Government found new reasons of oil and influence. The canal formed a source of strength and power for the empire and it is not coincidental that the end of the imperial attachment came at the same time as the wane of the empire. The multitude of shifts relating to the canal represented the changing role of Britain in the world. While the canal did not hold the empire together by itself, it certainly aided in the success of the empire. No matter what importance the canal held at a certain time, one statement proved accurate: the canal occupied a vital role in imperial strategy and policy from 1875 to 1956 and that strategy intertwined itself with the maintenance of the power and prestige of the British Empire. 


\section{References}

Primary Sources

Asquith, Herbert Henry, The Genesis of War London: Cassell \& Company Ltd., 1923.

Churchill, Randolph, The Rise and Fall of Sir Anthony Eden London: MacGibbon \& Kee, 1959.

Churchill, Winston, The Second World War Vol. 2 Their Finest Hour Boston: Houghton Mifflin Co., 1949.

The Second World War Vol. 4 The Hinge of Fate Boston: Houghton Mifflin Co., 1950.

Cooper, Chester, The Lion’s Last Roar: Suez 1956 New York: Harper \& Row Publishers, 1978.

Cromer, Lord, Modern Egypt 2 Vols. New York: Macmillan Co., 1916.

Eban, Abba, Abba Eban: An Autobiography New York: Random House, 1977.

Eden, Anthony, Full Circle: The Memoirs of Anthony Eden London: Cassell \& Company, 1966.

Gladstone, William, Midlothian Speeches New York: Humanities Press, 1971.

Glubb, John, A Soldier with the Arabs New York: Harper \& Brothers Publishers, 1957.

Hansard’s Parliamentary Debates. London: Cornelius Books, 1876-1882.

Heath, Edward, The Course of My Life: My Autobiography London: Hodder \& Staughton, 1998.

Heikal, Mohammad, Cutting the Lion's Tail: Suez Through Egyptian Eyes New York: 
Arbor House, 1987.

Hurewitz, J.C., Diplomacy in the Near and Middle East. Vol. 2 1914-1956 New York:

Octagon Books, 1972.

Lawrence, T.E. Revolt in the Desert Garden City N.Y.: Garden City Publishing Company, 1927.

Seven Pillars of Wisdom: A Triumph. New York: Garden City

Publishing Company, 1926.

Lloyd, Selwyn, Suez 1956: A Personal Account New York: Mayflower Books, 1978.

Macmillan, Harold, Tides of Fortune 1945-1955 New York: Harper \& Row, 1969. , Riding the Storm 1956-1959 New York: Harper \& Row, 1971.

Matthew, H.C.G., The Gladstone Diaries with Cabinet Minutes and Ministerial Correspondence, Volume X January 1881 to June 1883. Oxford: Clarendon Press, 1990.

Montgomery, Viscount, The Memoirs of Field Marshall, the Viscount Montgomery of Alamein, KG. New York: World Publishing Company, 1958.

Murphy, Robert, A Diplomat Among Warriors Garden City, N.J.: Doubleday, 1964.

Rabin, Yitzhak, The Rabin Memoirs Boston: Little, Brown, \& Company, 1979.

Ramm, Agatha ed., Political Correspondence of Mr. Gladstone and Lord Granville, 1876 -1886. Vol. 1 1870-1882, Oxford: Clarendon Press, 1963.

Shuckburgh, Evelyn, Descent to Suez: Foreign Office Diaries 1951-56: From 
Churchill's Last Government to the Suez Crisis Under His Hand picked Successor Anthony Eden. New York: W.W. Norton \& Company, 1986.

Zetland, Marquis of, ed., Letters of Disraeli to Lady Chesterfield and Lady Bradford. 2 vols. New York: D Appleton \& Co., 1929.

Secondary Sources

Balfour-Paul, Glen, End of Empire in the Middle East: Britain’s Relinquishment of Power in Her Last Three Dependencies Cambridge: Cambridge University Press, 1991.

Bartlett, C.J., British Foreign Policy in the Twentieth Century New York St. Martin’s Press, 1989.

Bierman, John, and Smith, Colin, The Battle of Alamain: Turning Point of World War II New York: Viking Press, 2001.

Blake, Robert, Disraeli. New York: St. Martin’s Press, 1967.

Bond, Brian, British Military Policy between the two World Wars Oxford: Clarendon Press, 1980.

Bourne, Kenneth, Foreign Policy of Victorian England Oxford: Clarendon Press, 1970.

Boyce, D. George, Decolonization and the British Empire, 1775-1997 London: Macmillan Press, LTD, 1999.

Bullard, Sir Reader, Britain and the Middle East from the Earliest Times to 1963 London: Hutchinson University Library, 1964. 
Busch, Briton Cooper, Britain, India, and the Arabs, 1914-1919 Berkeley, CA.: University of California Press, 1971.

Cannadine, David, Ornamentalism Oxford: Oxford University Press, 2001.

Cleveland, William, A History of the Modern Middle East Boulder, CO.: Westview Press, 1994.

Cohen, Michael, Palestine and the Great Powers 1945-1948 Princeton, N.J.: Princeton University Press, 1982. Palestine, Retreat from Mandate:the Making of British Policy, 1936 -1945. New York: Holmes \& Meier, 1978.

Daly, M.W., Empire on the Nile: The Anglo-Egyptian Sudan 1898-1934. Cambridge: Cambridge University Press, 1986.

Darwin, John, Britain and Decolonization: The Retreat from Empire in the Post War World New York: St. Martin’s Press, 1988.

Eldridge, C.C., England's Mission: the Imperial Idea in the Age of Gladstone and Disraeli. Chapel Hill, NC: University of North Carolina Press, 1993.

Epstein, Leon, British Politics in the Suez Crisis Urbana, IL.: University of Illinois Press, 1964.

Farnie, D.A., East and West of Suez: the Suez Canal in History 1854-1956. Oxford: Clarendon Press, 1969.

Farwell, Byron, Queen Victoria's Little Wars New York: W.W. Norton \& Company, 1972. 
The Great War in Africa. New York: W.W. Norton \& Company, 1986.

Ferrell, Robert H., Peace in Their Time: The Origins of the Kellogg-Briand Pact New York: W.W. Norton \& Company, 1953.

Feuchtwanger, Edward, Disraeli. London: Arnold Publishers, 2000.

Forster, E.M., A Passage to India New York: Modern Library, 1924.

Fromkin, David, A Peace to End All Peace: The Fall of the Ottoman Empire and the Creation of the Modern Middle East, New York: Avon Books, 1989.

Fussell, Paul, The Great War and Modern Memory Oxford: Oxford University Press, 1975.

Gatzke, Hans, ed., European Diplomacy between Two Wars 1919-1939 Chicago: Quadrangle Books, 1972.

Gardner, Brian, Allenby of Arabia: Lawrence’s General New York: Conrad McCann, Inc., 1965.

Gilbert, Martin, Winston Churchill Vol. III 1914-1916: the Challenge of War, Boston: Houghton Mifflin Co., 1971. , Winston Churchill, Vol. 7, 1941-1945, the Road to Victory Boston : Houghton Mifflin, 1986.

Glubb, John Bagot, Britain and the Arabs: A Study of Fifty Years 1908-1958. London: Hodder \& Staughton, 1959.

Gopal, Sarvelli, British Policy in India 1858-1905. Cambridge: Cambridge University 
Press, 1965.

Hahn, Peter, The U.S., Great Britain, and Egypt 1945-1956: Strategy and Diplomacy in the Early Cold War. Chapel Hill, N.C.: University of North Carolina Press, 1991. Hallberg, Charles, The Suez Canal: Its history and Diplomatic Importance. New York: Columbia University Press, 1931.

Harrison, Benjamin, Road to Suez: Gladstone and the Egyptian Crisis of 1882 (PhD. diss., University of Southern California, 1987.

Ingram, Edward, The British Empire as a World Power. London: Frank Cass, 2001.

James, Lawrence, The Rise and Fall of the British Empire. New York: St. Martin’s Press, 1994.

James, Robert Rhodes, Anthony Eden: A Biography New York: McGraw-Hill Book Company, 1986.

Jenkins, Roy, Churchill: A Biography New York: Farrar, Straus, and Giroux, 2001.

Karsh, Efraim and Karsh, Inari, Empires of the Sand: the Struggle for Mastery in the Middle East Cambridge, MA.: Harvard University Press, 1999.

Keegan, John, The First World War New York: Vantage Books, 1998. The Second World War New York, Viking Press, 1996.

Kipling, Rudyard. Kim New York: Doubleday, 1925.

Kolinsky, Martin, Britain’s War in the Middle East” Strategy and Diplomacy 1936-1942, _London: Macmillan Press LTD., 1999.

Knaplund, Paul, Gladstone’s Foreign Policy. New York: Harper \& Bactus, 1935. 
Liddell Hart, B.H., The War in Outline, 1914-1918 New York: Modern Library, 1936.

Louis, William Roger, The British Empire in the Middle East 1945-1951:Arab

Nationalism, the U.S., and Postwar Imperialism. Oxford: Clarendon Press, 1984 and Owen, Roger, Suez 1956: Crisis and Consequences Oxford: Claredon Press, 1989.

Marlowe, John , A History of Modern Egypt and Anglo-Egyptian Relations 1800-1956

Hamden, CT.: Archon Books, 1965.

Massie, Robert, Dreadnought: Britain, Germany, and the Coming of the Great War, New York: Ballantine Books, 1991.

McCarthy, Justin, The Ottoman Turks: An Introductory History to 1923 London: Longman, 1997.

McLeod, John, A History of India. London: Greenwood Press, 2002.

Metcalf, Thomas, Ideologies of the Raj Cambridge: Cambridge University Press, 1991.

Monroe, Elizabeth, Britain’s Moment in the Middle East Baltimore: Johns Hopkins University Press, 1981.

Morgan, Kenneth, Labour in Power 1945-1951 Oxford: Clarendon Press, 1984.

Morris, Benny, Righteous Victims: A Brief History of the Zionist-Arab Conflict 1881 -2001 New York: Vintage Books, 1999.

Neff, Donald, Warriors at Suez: Eisenhower takes America into the Middle East. New York: Linden Press, 1981.

Nish, Ian, Japanese Foreign Policy in the Interwar Period Westport, CT.: Praeger Press, 
2002.

Porter, Bernard, The Lion’s Share: A Short History of British Imperialism 1850-1990 London: Longman Group, 1995.

Pratt, Lawrence, East of Malta, West of Suez: Britain’s Mediterranean Crisis 1936-1939 Cambridge: Cambridge University Press, 1975.

Robertson, Terence, Crisis: the Inside Story of the Suez Conspiracy New York: Atheneum, 1965.

Robinson, Robert and Gallagher, John, Africa and the Victorians: the Official Mind of Imperialism, London: MacMillan \& Co. LTD., 1965.

Sayigh, Yezid, Armed Struggle and the Search for State Oxford: Oxford University Press, 1999.

Schonfield, Hugh, The Suez Canal in Peace and War 1869-1969. Coral Gables, Fl.: University of Miami Press, 1969.

Searight, Sarah, The British in the Middle East New York: Atheneum, 1970.

Silverfarb, Daniel, Britain’s Informal Empire in the Middle East New York: Oxford University Press, 1986.

Sluglett, Peter, Britain in Iraq 1914-1932 London: Ithaca Press, 1976.

Thornton, A.P., The Imperial Idea and its Enemies. London: MacMillan \& Co., LTD., 1958.

Westrate, Bruce, The Arab Bureau: British Policy in the Middle East 1916-1920. (State Park, PA.: Pennsylvania State University Press, 1992. 
Wilson, Mary C. King Abdullah, Britain, and the Making of Jordan Cambridge: Cambridge University Press, 1987.

Articles

Bell, Christopher, "The Singapore Strategy and the Deterrence of Japan: Winston Churchill, the Admiralty, and the Dispatch of Force Z,” in English Historical Review Vol. 116, No. 467(2001):604-634.

Clifford, Nicholas, "Britain, America, and the Far East 1937-1941:A Failure in Cooperation,” in Journal of British Studies Vol. 3, No.1 (1963):137-154.

Francis, Martin, “Tears, Tantrums, and Bared Teeth: The Emotional Economy of Three Conservative Prime Ministers, 1951-1963,” in Journal of British Studies Vol. 41, No. 3 (July 2002):354-387.

Morewood, Steven, "Protecting the Jugular Vein of Empire: the Suez Canal in British Defense Strategy 1919-1941, “ in War \& Society Vol. 10, No. 1 (May 1992).

Negrin, Ralph, “The Press and the Suez Crisis: A Myth Re-examined," in The Historical Journal Vol. 25, No. 4 (December 1982):975-984.

Parmentier, Guillaume, “The British Press in the Suez Crisis,” in The Historical Journal Vol. 23, No. 2 (June 1980):435-445. 


\title{
Curriculum Vitae
}

\author{
Matt Church \\ 2549 Glenmary Avenue \#3 \\ Louisville, KY 40204 \\ 502-876-3995 \\ e-mail-londongimp55@yahoo.com
}

\section{Education}

\author{
M.A. History \\ University of Louisville \\ GPA- 3.88 in progress \\ 2002-2004
B.A. History
Bellarmine University
GPA- 3.87
1997-2001

\section{Study Abroad}

Cambridge University History Summer School, July 9-29, 2000. Class II:i. Coursework in Arab-Israeli Conflict with Dr. Yezid Sayigh and Yugoslav History with Dr. Michael Stenton.

Field Seminar in Italy May 1999. History 241: The Lives of St. Francis of Assisi and Robert Bellarmine. 


\section{$\underline{\text { Awards and Honors }}$}

Monsignor Horrigan Scholarship for Academic Excellence from Bellarmine University 1997-2001.

Welsh Scholarship for Excellence in History, Bellarmine History Department, 19982001.

Louisville Committee on Foreign Relations Scholarship, 2000-2001.

Bellarmine University Faculty Merit Award in Social Sciences, May 2001.

Barker Service Award for Academic Excellence and Service to the School, Bellarmine University, May 2001.

In Veritatis Amore Award for Outstanding Male Graduate as voted by the faculty, Bellarmine University, May 2001.

Ryant Memorial Award, University of Louisville Fall 2002

College of Arts \& Sciences First Year Graduate Student Scholarship, University of Louisville, Fall 2002.

University of Louisville History Department Graduate Student scholarship, 2002-2003. University of Louisville History Department Graduate Assistantship 2003-2004 Second Place Paper, Graduate Division, Kentucky Phi Alpha Theta Regional Conference, 2004

Inducted into Phi Sigma Tau Philosophy Honor Society January 2000.

Inducted into Kappa Gama Pi National Catholic Honor Society, May 2001

Inducted into Phi Alpha Theta, 2003. 


\section{$\underline{\text { Panel/Invited Lectures }}$}

-Panel Discussion on events of September $11^{\text {th }}$, Bellarmine University October 2001 -Lecture “ U.S.-Middle Eastern Relations.” Students for Social Justice, Bellarmine University, February 2002.

-Panel Discussion on Arab-Israeli Conflict, Louisville Cathedral Heritage Foundation, February 2003.

\section{Academic Experience}

-Academic Resource Center Tutor, Bellarmine University 1999-2001 for the following courses: History 116: Western World I

History 117: Western World II

History 201: U.S. History to 1877

History 202: U.S. History 1877 to the present

History 323: Methodology of History

Political Science 101: American National Government

Political Science 203: Early Political Thought

Political Science 204: Modern Political Thought

-Learning Assistant for History 102-09, Civilizations II taught by Dr. Justin McCarthy

2002-2003.

-Research Assistant for Dr. Jonathan Ziskind, Summer 2003

-Instructor General Studies 101 Arts and Sciences Orientation Fall 2003

-Graduate Teaching Assistant Dean’s Office University of Louisville Fall 2003

Taught the student Support Services portion of

General Studies 101: Campus Culture

\section{$\underline{\text { Presentations }}$}


"Eden and the Suez Crisis.” Presented at Kentucky Phi Alpha Theta Conference, Morehead State University, April 12th 2003.

“The Imperial Attachment to the Suez Canal from 1914 to 1922” presented at Kentucky Phi Alpha Theta Conference, University of Louisville, April 3 ${ }^{\text {rd }}, 2003$

\section{Publications}

-“Conspiracy in the Congo Region” in Ariel, Bellarmine University Literary Magazine, 1999.

-“Messianic Beliefs of the Essenes.” in Ariel, Bellarmine University Literary Magazine, 2002.

-“ The Imperial Attachment to the Suez Canal from 1914 to 1945” in Nu Xi Chapter

History Journal Spring 2004. This is the online journal for the University of Louisville Phi Alpha Theta Chapter.

\section{Other}

-Outstanding Delegate1998 Midwest Model Arab League at Miami University of Ohio.

-Outstanding Delegate1999 Midwest Model Arab League at Miami University of Ohio.

-Member Outstanding Delegation 1999 Midwest Model Arab League at Miami University of Ohio.

-Chairman Security Affairs Committee 2000 Midwest Model Arab League at Miami University of Ohio.

-Member Outstanding Delegation 2001 Midwest Model Arab League at Miami University of Ohio. 
-Outstanding Delegate 2002 Midwest Model Arab League at Miami University of Ohio. -Member Honorable Mention Delegation 2002 Midwest Model Arab League at Miami University of Ohio.

-Bellarmine University Student Government 1999-2000.

-Bellarmine University Political Science Club: Secretary 1998-99, Vice President 1999 -2000, President 2000-2001.

-Bellarmine University Chapter of Phi Sigma Tau: Vice President 1999-2000, President 2000-2001.

-Bellarmine University English Society: President 2000-2001.

-Member Ariel, Bellarmine University Literary Magazine, Editorial Board 2000-2001.

-Bellarmine Honor Code Review Committee 2000-2001.

-Member Ethics Bowl Championship Team, Bellarmine University, Spring 2002.

Memberships

Phi Alpha Theta International History Honor Society

Phi Sigma Tau International Philosophy Honor Society

Kappa Gamma Pi National Catholic Graduate Honor Society

North American Conference of British Studies

English Speaking-Union Kentucky Branch 
